\title{
The Making of the Post-War Paradigm in American Intellectual Property Law
}

Steven Wilf

University of Connecticut School of Law

Follow this and additional works at: https://opencommons.uconn.edu/law_papers

Part of the Intellectual Property Law Commons, Law and Economics Commons, and the Legal History Commons

\section{Recommended Citation}

Wilf, Steven, "The Making of the Post-War Paradigm in American Intellectual Property Law" (2008). Faculty Articles and Papers. 173. https://opencommons.uconn.edu/law_papers/173 


\section{HEINONLINE}

Citation: 31 Colum. J.L. \& Arts 139 2007-2008

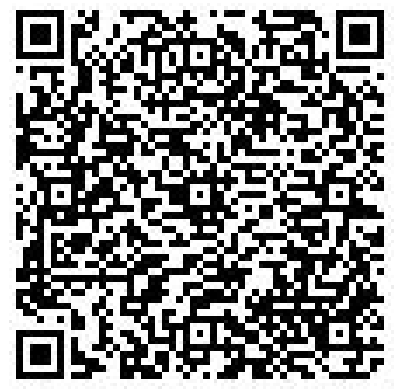

Content downloaded/printed from

HeinOnline (http://heinonline.org)

Mon Aug 15 17:35:24 2016

-- Your use of this HeinOnline PDF indicates your acceptance of HeinOnline's Terms and Conditions of the license agreement available at http://heinonline.org/HOL/License

-- The search text of this PDF is generated from uncorrected OCR text.

-- To obtain permission to use this article beyond the scope of your HeinOnline license, please use:

https://www.copyright.com/ccc/basicSearch.do? \&operation $=$ go\&search Type $=0$ \&lastSearch $=$ simple\&all=on\&titleOrStd $N o=1544-4848$ 


\title{
The Making of the Post-War Paradigm in American Intellectual Property Law
}

\author{
Steven Wilf*
}

INTRODUCTION

I. Intellectual Property and the Problem of Monopoly............................. 149

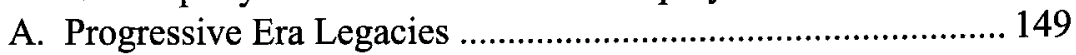

B. New Deal Ambivalence..................................................... 150

II. Trademarks, Consumer Psychology, and the Pax Keynesiana ........... 153

A. Product Differentiation and Monopoly ................................... 154

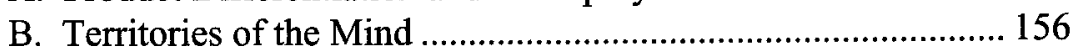

C. Trademark and the Birth of the Consumer Republic................ 160

D. From Symbol to Act ........................................................... 171

III. Copyright and the Politics of Intellectual Property's Industrial

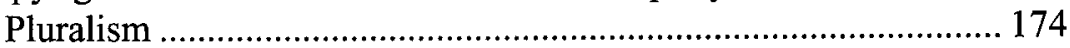

A. Copyright in an Age of Mechanical Reproduction.................. 176

B. Private Ordering and Industrial Design ................................. 183

IV. Patents as Corporate Property ......................................................... 191

A. Challenging the Market Power of Patents ............................... 192

B. The Limits of New Deal Reform ............................................. 198

V. Conclusion ................................................................................... 203

A. Towards a New History of Intellectual Property..................... 203

B. Intellectual Property and its Post-War Discontents: From Political Economy to Citizenship...................................... 206

\section{INTRODUCTION}

The field of intellectual property stands at a critical juncture where traditional balances between the protection of owner's rights and the access of the public to

* Professor of Law, University of Connecticut School of Law. The title of this paper is borrowed from Katherine Van Wezel Stone's classic article, The Post-War Paradigm in American Labor Law, 90 YALE L.J. 1509 (1981). I would like to thank the participants in conferences and workshops at the law faculties of the University of Wisconsin, the University of Connecticut, Boston University, Cardozo Law School, Haifa University, Tel Aviv University, and Hebrew University. I particularly appreciate the comments of Robert Bone, Wendy Gordon, Hillary Greene, Jennifer Klein, Assaf Likhovski, Willajeanne McLean, Jeremy Paul, Guy Pessach, Richard Ross, Bruce Smith, Katherine Van Wezel Stone, and Carol Weisbrod. Julia Flores, David Lawton and Julia Sitarz provided able research assistance. Finally, I would like to express my appreciation to the Schechter family for providing access to Frank Schechter's papers. 
knowledge seem to be breaking down. No longer is intellectual property spoken of as a model self-regulatory regime. Most notably, attention has been focused upon the remarkable expansion of its scope in the post-war period. Commentators from a wide range of backgrounds-from modern art to emerging biotechnology to traditional fields of print culture and mechanical invention - agree that intellectual property rights have become increasingly far-reaching.

Indeed, there has been an unprecedented expansion in the subject matter covered by intellectual property: in the length of terms of protection; in the robust nature of exclusive rights; in the ability to use a complex array of legal strategies in conjunction with new forms of technological control over expression; and even in the myriad of available civil and criminal sanctions. This Article attempts to trace the dominant themes marking the dramatic enlargement of intellectual property in the twentieth century. It explores how as a result of events in the 1930s and 1940s, including responses to the global economic crisis as well as significant social and cultural change, we arrived at this point. What brought about the transformation in the post-war period, which enabled courts and legislators to recognize intellectual property rights as the comerstone of a dynamic modern economy?

Over a half-century ago, the New Deal initiated a new expansive epoch in intellectual property law. For the first time, products of the mind were seen as essential instruments for industrial growth. A national legislative scheme, the Lanham Act, ${ }^{1}$ was enacted to provide comprehensive protection of trademarks in response to the rise of consumerism; statutory and self-help mechanisms were introduced to change the face of copyright from protection of literary property to a framework for organizing industrial property; and patent law responded to emerging corporate control of invention.

No doubt the challenge of the Great Depression and the rise of an increasingly regulatory federal government contributed to the rethinking of intellectual property law. But it is important to keep in mind the wide variety of factors that influenced the New Deal architects of intellectual property policy. These include unease with increasingly large-scale modes of industrial governance inherited from the Progressive Era, heightened competition within national and international markets, emerging new media such as radio and motion pictures, legal realist rethinking of the relationship between law and the social sciences, and ambitious new theories of the role of information as a predicate for citizenship. A core operative feature of New Deal conceptions of intellectual property was the seamless interaction of economics and culture. Not surprisingly, legal change was sporadic and often deeply contested. My intent is to reconstruct the debates that took place during the New Deal-especially the back and forth between competing theories of property and competition-with all their complexity.

New Deal intellectual property policy was Janus-faced. As expansive rights in knowledge became a cornerstone of industrial policy during this period, intellectual property debates simultaneously turned towards democratic politics. Issues of wealth distribution, the impact of protecting new media technologies on civil 
society, the linking of intellectual property and cultural discourse, and the idea that intellectual property legal norms may be recalibrated in accordance with shifting interest groups are also legacies of the New Deal debates. This narrative has significant implications for our time, when insistent political pressure has come from those who see the growing capaciousness of private proprietary rights over the products of the mind as a new enclosure movement. ${ }^{2}$ The promise of easing the dissemination of information through new technologies and, at the same time, the use of such technologies as the internet for rent-seeking has sharpened our awareness of the issue of control over knowledge, and often heightened the discontent with the existing legal boundaries of protection. However, unlike many of the New Deal debates, calls for enlarging the public domain as a cultural commons are often premised solely upon conceptions of civil society and fail to address the importance of intellectual property for a national economic policy.

The wide-ranging New Deal disputes over intellectual property were notable because they mixed economic issues-both aggregate and allocative/distributive outcomes - with questions of the role of the public sphere in a participatory democracy. The core of the debate, however, was the relationship between monopoly and intellectual property. This tension animated discussions pertaining to all the major intellectual property regimes. A narrative arc connects Progressive Era hostility to the idea of intellectual property as a form of trust to the New Deal embrace of intellectual property as an engine of economic development. This shift was often uneven and ridden with anxieties for New Deal lawyers, even as these changes were taking place.

My account therefore provides historical traction for current normative debates about whether anti-competition law might be used to regulate the breadth of intellectual property protection. Moreover, different regimes experienced different historical trajectories in the course of the early to mid twentieth century. Progressive Era distrust of the monopoly aspects of trademark and copyright was to a large extent resolved as New Deal legal architects sought to harness intellectual property as a core component of its industrial policy. ${ }^{3}$ Trademark emerged as the cornerstone of a consumer-oriented economy, and copyright was identified with new media interests and industrial design. Patent law, however, continued to be disfavored. ${ }^{4}$ It retained its prior reputation as a bastion of monopoly. Patents raised significant anti-competition concerns for New Deal lawyers.

The doctrinal source of the tension between public concerns about monopoly and the vesting of private property rights in knowledge lay in the late nineteenth

2. Enclosure refers to removing uses of information from the public domain and placing them in an enclosed domain where they are subject to an owner's exclusive control. The image of enclosure draws heavily upon real property discussions, and has found its way into the scholarly intellectual property literature, see Yochai Benkler, Free as the Air to Common Use: First Amendment Constraints on Enclosure of the Public Domain, 74 N.Y.U. L. REV. 354 (1999). The literature criticizing the scope of intellectual property protection, especially copyright, is vast. See, e.g., LAWRENCE LESSIG, FREE Culture: How Big Media Uses Technology and the LaW to Lock Down Culture and CONTROL CREATIVITY (2004).

3. See infra Parts II and III.

4. See infra Part IV. 
century. Progressive Era jurisprudence faced a dilemma. Intellectual property's exclusive rights created what on its face was a monopoly, and nothing-or almost nothing-was more abhorrent to the Progressive legal mind than monopoly. ${ }^{5}$ The contradiction of establishing exclusive rights in intangibles, while at the same time seeking to curb anti-competitive behavior through antitrust and related doctrines, animated much of the late nineteenth and early twentieth-century approach to intellectual property. I will examine some of the anxieties, doctrinal dissonance, and tensions that emerged from this dilemma.

The New Deal period witnessed a marked shift in the attitude towards competition. A number of influential New Deal figures attacked the Progressive Era's hostility towards cartels. While New Deal jurisprudence certainly reflected a variety of stances towards intellectual property, it is fair to say that overall anxieties about the connection between monopoly and intangible mental products receded.

This Article is the first sustained discussion of this transformation, which might be described as something between a sea-change and a rupture in legal thinking, and which provided the groundwork for the post-war ascendancy of robust intellectual property rights. It identifies the untangling of intellectual property from the legal rhetoric of monopoly. Through a discussion of the political economy as basis for intellectual property doctrine in the 1930 s and 1940s, it is possible to unpack our current policy decisions. The New Deal undoubtedly gave rise to the post-war paradigm of intellectual property law, an ever-expanding galaxy of protections, which as a legal conceptual structure we still inhabit. Four major features mark the post-war paradigm.

First, intellectual property law grew to be seen as a national and international enterprise. Export of United States manufactured and cultural products set the stage for the expansion of domestic intellectual property law's geographic compass, an increasingly broad reach which we experience today. For copyright, this meant extending domestic protection beyond national borders. United States phonograph recordings and motion picture production found international markets. Most of the failed legislative proposals seeking to revise the Copyright Act of $1909^{6}$ provided for the adherence of the United States to the International Copyright Union, founded by the Berne Convention of $1886 .^{7}$ Most notably, the Vestal Bill (1931) ${ }^{8}$ and the Duffy Bill $(1935)^{9}$ would have authorized the United States to become a signatory to the revised Berne Convention. The fact that the Berne Convention vested copyright rights automatically upon creation, and the 1909 Copyright Act

5. See, e.g., Homer Cummings, The Unsolved Problem of Monopoly, 72 U.S. L. REV. 23, 23 (1938) (writing of monopoly concentration and echoing Progressive Era anti-monopoly sentiments: "[i]f this is what democracy comes to, we must amend our ways or confess judgment in the face of the world . . . unless we destroy monopoly, monopoly will find ways to destroy most of our reforms and, in the end, lower the standards of our common life").

6. Pub. L. No. 349, 35 Stat. 1075 (1909) (replaced by the Copyright Act of 1976).

7. Revised at Paris (1896), Berlin (1908), and Rome (1928). The United States would ultimately become a signatory to the Berne Convention over a hundred years later with the Berne Convention Implementation Act, Pub. L. No. 100-568, 102 Stat. 2853 (1988).

8. H.R. 12549, 71 st Cong. (1931).

9. S. 3047, 74th Cong. (1935) (substituted for S. 2465 which was withdrawn). 
conditioned rights upon formalities such as registration and notice, certainly created a barrier to compliance with new international norms. ${ }^{10}$ However, more significant were the difficulties of achieving any revision of the Copyright Act, since the various interest groups vested in the question of copyright revision were afraid to alter the status quo. ${ }^{11}$

While many New Deal copyright proposals promoted entering into an international framework, trademark was ushered into a newly established national system. Passed in 1946, the Lanham Act provided for substantive federal regulation of trademarks in a national market of goods and services. ${ }^{12}$ Registration of a trademark under the Lanham Act established constructive notice for trademarks throughout the United States, even in those places where a product had not yet been used in commerce or even advertised. ${ }^{13}$ This provision implicitly recognized the country as a single seamless commercial market linked by vast communication and transportation networks. The Lanham Act fostered a consumer republic founded upon a shared world of signs, symbols, and products. Promulgated under the umbrella of the federal government's broad powers in regulating interstate commerce, the Lanham Act is, I will argue, a quintessential New Deal statute.

Even patent law was affected by international concerns, since there was a keen awareness in the midst of wartime industrial production that many important patents remained in the hands of foreign combines. Foreign patents were frequently raised as an illustration of the concern with patent's monopoly power. ${ }^{14}$

Second, intellectual property was increasingly seen as property. I am not suggesting that property language did not animate pre-New Deal intellectual property law. However, earlier notions of exclusive rights as property were often framed in common law terms and limited by the stretch of common law analogues to inchoate forms of knowledge. ${ }^{15}$ Private property was articulated in more

10. See SAM RiCKETSON \& JANE C. GINSBURG, InTERNATIONAL COPYRIGHT AND NeIGHBourINg Rights: THE BERNe CONVENTION AND BEYOND 2-120 (2d ed. 2006); Barbara A. Ringer, The Role of the United States in International Copyright-Past, Present, and Future, 56 GEO. L.J. $1050,1052-53$ (1968).

11. See infra Part IV.A.

12. 15 U.S.C. $\S \S 1051-1127(2000)$.

13. Id.

14. E.g., Trading With the Enemy Act of 1917, 50. U.S.C. $\S 10$ (repealed 1946) (authorized the President to license to U.S. citizens enemy-owned patents where these were necessary for the successful prosecution of the war).

15. Take, for example, the legal conundrum of whether individuals should be able to receive compensation for ideas disclosed to third parties, who use those ideas for their own benefit, absent the existence of any sort of express contract. In a case where an individual disclosed to a department store owner a scheme for an employee-based prize contest in order to secure new customers, and was disappointed when he was not compensated for the use of his plan, the court likened ideas to ferae naturae. Under this view, ideas are analogues to wild creatures-they are property when within one's domain, but upon disclosure these ideas are no longer under dominion. William T. Birmingham, $A$ Critical Analysis of the Infringement of Ideas, 5 COPYRIGHT L. SYMP. (ASCAP) 107 (1954) (citing Edwin J. Brunner v. Stix, Baer, \& Fuller Co., 181 S.W.2d 643 (Mo. 1944)). See also Warwick v. De Mayo, 213 S.W.2d 392 (Mo. 1948) (denying recovery where the plaintiff sought to recover damages for the misappropriation of an invention, a vending machine for the dispensing of soft drinks, which he 
absolute terms and, as the guarantor of individual liberty, insulated from wholesale government intervention. In contrast to nineteenth-century jurists, New Deal thinkers brought an entire regulatory apparatus to bear upon intellectual property law. Influenced by legal realists such as Robert L. Hale, the architects of New Deal intellectual property law recognized the relationship between property and power. ${ }^{16}$

The fact that legal doctrine provided private entities with coercive leverage over other parties had special significance in intellectual property law, where property rules were less intuitive and less settled. In the area of trademark law, for example, Felix Cohen called for a limit to extending protection to marks where there was no clear public interest. ${ }^{17}$ As we shall see, this led other New Deal lawyers to strongly theorize alternative notions of public benefit. Indeed, conceiving of intellectual property qua property allowed the debate to proceed simultaneously in two directions. While justifying a larger bundle of rights, propertized notions of intellectual property also established the basis for limiting rights in much the same way as traditional property rights were restricted in the 1930s and 1940s for competing private rights or for public purposes. This was the source of robust redefinitions of what might be considered the public stake in the products of knowledge. ${ }^{18}$ Propertization, a concept commonly applied to contemporary intellectual property law as if it has an immutable meaning, must be situated within the particular period's understanding of property law. ${ }^{19}$

Third, the New Deal witnessed the precipitous decline of Progressive Era anxieties about monopolistic aspects of intellectual property. New Deal lawyers accepted anti-competitive forms of legal governance as a way of dealing with the downward spiraling of wages and prices and with general deflationary pressure. With diminishing concern about the effects of the control of intellectual property assets, however, came a post-war acceptance of the contribution of various interest groups in asserting market power. ${ }^{20}$ New Deal policy makers envisioned

disclosed to the defendant, because the court took the view that property in ideas is analogous to a negotiable instrument, whereby title passes by delivery - or, in the case of an idea, with disclosure). For a general late nineteenth-century claim that intellectual property is a direct analogue to real property, see N.S. Shaler, ThOUghts ON THE NATURE OF INTELlectual PROPERTY AND ITS IMPORTANCE to THE STATE (1878).

16. See Robert L. Hale, Coercion and Distribution in a Supposedly Non-coercive State, 38 PoL. SCI. Q. 470, $471-77$ (1923); Ilana Waxman, Hale's Legacy: Why Private Property is Not a Synonym for Liberty, 57 HASTINGS L.J. 1009, 1009-19 (2006); see also GREGORY S. ALEXANDER, COMMODITY \& PROPRIETY: COMPETING VISIONS OF PROPERTY IN AMERICAN LEGAL THOUGHT 1776-1970 335-51 (1997).

17. Felix Cohen, Transcendental Nonsense and the Functional Approach, 35 Colum. L. ReV. 809, 814-15 (1935) (discussed at length infra Part III).

18. See Cass R. Sunstein, The Beard Thesis and Franklin Roosevelt, 56 GEO. WASH. L. REV. 114, 120-21 (1987).

19. See generally Justin Hughes, Copyright and Incomplete Historiographies: Of Piracy, Propertization, and Thomas Jefferson, 79 S. CAL. L. REV. 993 (2006). For a description of an important exception to the conventional non-historical approach to propertized intellectual property, see generally Keith Aoki, (Intellectual) Property and Sovereignty: Notes Toward a Cultural Geography of Authorship, 48 STAN. L. REV. 1293 (1996) (relating definitions of intellectual property to changing notions of sovereignty).

20. See, e.g., Jamesbury Corp. v. Litton Indus. Prods., Inc., 756 F.2d 1556, 1559 (Fed. Cir. 1985) 
intellectual property law as the negotiated outcome of competing interest groups.

Granting parties exclusive rights was nevertheless seen as troubling under patent law, which followed a very different doctrinal evolution than trademark or copyright law. As shall be discussed below, the lingering identification of patent law with the evils of monopoly — even as copyright and trademark doctrine largely shed the concern with anti-competitive behavior-continued to result in patent cases being decided against defendants in federal courts. This persistent distrust of patents remained decades after the end of the New Deal Era. Only with the 1982 creation of a specialized appellate court for patent cases, the Federal Circuit, was a more sympathetic venue available for plaintiffs in patent infringement claims. ${ }^{21}$

Fourth, with the New Deal came an acceptance of the role played by intellectual property exclusive rights as a motor driving the economy as a whole. Patent rights would contribute to the development of a technical infrastructure for a modern industrial economy. Copyright might be used for protection of America's cultural industries, such as radio and cinema (which would become a major export product), and for the protection of industrial design. Trademark law would stimulate consumer appetite for mass produced goods. The focus on consumption was part of a vision of a pax keynesiana, whereby domestic industrial peace depended upon mass production with rising levels of productivity capable of meeting consumer demand. With trademarks differentiating among a wide array of consumer products, this consumer-driven economy would tirelessly stimulate purchasers' desires for new durable goods.

Recently, a well-developed historical literature has emerged on advertising and consumption in the early twentieth century. ${ }^{22}$ This Article situates intellectual

("the characterization of a patent [to a jury] as a 'monopoly' is misdirected," since a patent is a property right).

21. Federal Courts Improvement Act, Pub. L. No. 97-164, 96 Stat. 25 (1982).

22. See generally JACKSON LEARS, FABLES OF ABUNDANCE: A CULTURAL HiSTORY OF ADVERTISING IN AMERICA (1994); ROLAND MARCHAND, ADVERTISING THE AMERICAN DREAM: MAKING WAY FOR MODERNITY, 1920-1940 (1985) [hereinafter MARCHAND, ADVERTISING THE AMERICAN DREAM]; STEPHEN FOX, THE MIRROR MAKERS: A History OF AMERICAN ADVERTISING AND ITS CREATORS (Univ. of Ill. Press 1997) (1984); STUART EwEN, CAPTAINS OF CONSCIOUSNESS: ADVERTISING AND THE SOCIAL ROOTS OF THE CONSUMER CULTURE (Basic Books 2001) (1976); GARY CROSS, AN ALl-CONSUMING CENTURY: WHY COMMERCIALISM WON IN MODERN AMERICA (2002); Daniel HoROWITZ, THE MORALity OF SPENDING: ATTITUdES TOWARD THE CONSUMER SOCIETY IN AMERICA 1875-1940 (I.R. Dee 1992) (1985) [hereinafter HoRowITZ, THE MORALITY OF SPENDING]; DANIEl HoRowitz, THE ANXIETIES OF AFFLUENCE: CRITIQUES OF AMERICAN CONSUMER CULTURE 1939-1979 (2004) [hereinafter HoROWITZ, THE ANXIETIES OF AFFLUENCE]; MEG JACOBS, POCKETBOoK PoliticS: ECONOMIC Citizenship IN TWENTIETH-CENTURY AMERICA (2005); THE SEX OF THINGS: GENDER AND CONSUMPTION IN Historical PERSPECTIVE (Victoria de Grazia and Ellen Furlough, eds., 1996); CONSUMER SOCIETY IN AMERICAN HISTORY: A READER (Lawrence B. Glickman, ed., 1991); Susan Strasser, Satisfaction Guaranteed: The Making of the American Mass Market

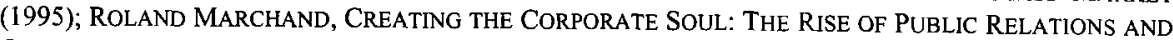
CORPORATE IMAGERY IN AMERICAN BIg Business (1998) [hereinafter MARCHAND, CREATING THE Corporate Soul]; James livingston, Pragmatism and the Political Economy of Cultural Revolution, 1850-1940 (1994); Susan Benson, COUNTER Cultures: SAleswomen, MaNAGERS, AND CUSTOMERS IN AMERICAN DEPARTMENT STORES 1890-1940 (1986); WILLIAM LEACH, LAND OF DESIRE: MERCHANTS, POWER, AND THE RISE OF A NEW AMERICAN Culture (1993) [hereinafter LEACH, LAND OF DESIRE]; William Leach, Transformations in a Culture of Consumption: Women and 
property within the broader trajectory of the rise of a consumer culture, including the expansion of advertising and productive capacities in the twentieth century. More importantly, it addresses the subtle, interactive relationship of intellectual property, legal norms, and political economy. During the 1920s and 1930s, Americans became acutely aware of their new collective role as consumers. This new role emerged from changing vistas within the American social landscape in the early part of the century: new technologies, urbanization and industrialization, greater social mobility, and a robust national market economy. ${ }^{23}$ It prompted the demand for legal rules vesting intellectual property with more protections qua property.

These new rules, in turn constitutive of this property, grounded a new kind of citizenship founded upon intangible property. New Deal citizens operated within a remarkably lively, untrammeled world of radio, film, and visual arts; consumer goods were increasingly differentiated, and thus, might be appropriated to establish different personal and collective identities. Diverse ethnic and racial groups leveraged increasingly differentiated psychological and material landscapes to carve out robust public spheres of their own. New technologies empowered individuals, freeing them from dependency upon earlier labor structures. The wasteland of copyrighted media, the materialism of a country awash in advertising and consumer goods, and the soulless quality of technology have all been the subject of sustained social criticism. ${ }^{24}$ But, as I will suggest, the New Deal linking of intellectual property and political economy predicated a new form of citizenship which, no matter how unsettling, was astonishingly vibrant. The ability to buy and spend as never before, "the democratization of desire," allowed the material world of goods and the expressive world of media to become the sinews of personal and collective utopias for many who were previously politically marginalized. ${ }^{25}$ Intellectual property served to create the legal infrastructure for what historian Lizabeth Cohen has called a "consumer's republic."26

But if historical investigation shows that our post-war paradigm emerged as a set of self-conscious decisions shaped by the political economy of the New Deal, it should also prod us to ask normative questions. The idea of intellectual property as an economic motor has had significant influence upon the shaping of intellectual property policy for both legislatures and courts. At the legislative level, for

Department Stores, 1890-1925, 71 J. AM. HIST. 319-42 (1984) [hereinafter Leach, Transformations]; Lawrence A. Glickman, Inventing the "American Standard of Living": Gender, Race, and WorkingClass Identity 1880-1925, 34 LABOR HIST. 221 (1993). None of these works discusses the relationship between intellectual property law and the emergence of consumer culture. See generally PETER N. STEARNS, CONSUMERISM IN WORLD HISTORY: THE GLOBAL TRANSFORMATION OF DESIRE (Routledge 2006) (2001).

23. Richard Wightman Fox, Epitaph for Middletown: Robert S. Lynd and the Analysis of Consumer Culture, in THE CULTURE OF CONSUMPTION: CRITICAL ESSAYS IN AMERICAN HISTORY 18801980 101-141 (Richard Wightman Fox and T.J. Jackson Lears eds. 1983).

24. See Horowitz, THE ANXIETIES OF AFFLUENCE, supra note 22, at 20-47 (describing how cultural critics developed a sustained anti-consumer discourse from the Great Depression onwards).

25. See LEACH, LAND OF DESIRE, supra note 23, at 7-8.

26. Lizabeth CoHen, A Consumers' Republic: The Politics of Mass Consumption in AMERICA (2003) [hereinafter COHEN, A CONSUMERS' REPUBLIC]. 
example, Congress recently was willing to expand the usual term of copyright for individual authors to life plus seventy years as a mechanism to allow further exploitation of American intellectual property assets abroad. ${ }^{27}$ However, the use of efficiency arguments to promote intellectual property protection as good for the economy as a whole often ignores whose interest might benefit from an expansion of exclusive rights. As twentieth-century economic historian Charles Maier has suggested, "Cui bono? is not the only question a historian should pose, but it is a useful one to start with."28 The focus on aggregate growth, I would argue, has obscured the question of gains and losses for various parties.

Part I introduces the problem of anti-competition and traces its evolution from the Progressive Era through the New Deal. It surveys encounters between anticompetition law and intellectual property. Drawing upon the history of consumption, Part II traces the emergence of new ways of thinking about trademark law. Much of the narrative in this section is constructed around the figure of Frank Schechter, a prolific practitioner with an academic bent who embodied the New Deal's growing interest in trademarks.

Part III focuses on copyright. It consists of two case studies showing how the New Deal negotiated competing interests in copyright involving sound recordings and industrial design within the fashion industry. The first case study explores the debates over the licensing of sound recordings and discusses how Congress was the fulcrum point for demands from competing interests. A parallel narrative about industrial design unpacks the mechanisms used to protect industrial design, especially in the field of apparel manufacturing. In the case of sound recordings, a policing mechanism existed in the form of a royalty collection society, but various interest groups contested its broad market power. By contrast, there was broad support for the protection of fashion designs. However, the different self-help mechanisms used for protection proved inadequate. Part IV tells the story of how patent was left behind as trademark and copyright shed their association with monopoly.

Finally, Part V highlights the historical and normative contributions of this Article. Examining the problems with the three major justifications for intellectual property-labor theory, personality theory, and utilitarian theory-this section advances the argument that historical analysis provides an understanding of the contingent nature of intellectual property rights. In contradistinction to the received narrative of intellectual property emerging in response to new technologies, I call for a robust history of intellectual property grounded on the idea of evolving notions of political economy.

The second, and concluding, section of Part $\mathrm{V}$ underscores the normative significance of understanding the history of twentieth-century regulation of knowledge. It describes how, through the expansion of intellectual property rights

27. Sonny Bono Copyright Term Extension Act, Pub. L. No. 105-298, 112 Stat. 2827 (1998); see Eldred v. Ashcroft, 537 U.S. 186 (2003) (holding that the Copyright Term Extension Act's lengthening of existing copyright terms did not exceed Congress' power under Article I, Section 8).

28. Charles Maier, In SEarch of Stability: Explorations IN Historical POlitical ECONOMY 7 (1987). 
as industrial policy and the linking of intellectual property protection and trade, we continue to inhabit an intellectual property landscape defined by the New Deal. However, this section also suggests a forgotten aspect of intellectual property inherited from the New Deal Era-its role in establishing the contours of citizenship. By passing the Lanham Act, Congress created a robust federal trademark law resting upon the authority of the Commerce Clause as a cornerstone of the consumer republic. Identities and affinities were shaped by psychological identification with particular modes of consumption. The social meaning of consumer products, preferences and distinctions served as the foundation for a differentiated social structure. ${ }^{29}$ Copyright set the contours of the emerging media of radio and film, a new public sphere for an age of mechanical reproduction. In the case of industrial design copyright, there were experiments with bringing the model of Industrial pluralism to intellectual property. Patent law was deeply implicated in the shifting relationship between corporation and citizen.

New Deal debates about intellectual property reflected emerging notions of citizenship. Citizens were consumers of packaged goods and big-studio Hollywood films, participants in a remarkably diverse landscape of intellectual property production. Moreover, if intellectual property had a significant role in forging a new knowledge-based economy, all citizens had a vested stake in its production. The New Deal sought to create an intellectual property framework for a modern industrial society. Political interventions, such as the role of Congress as the umpire among competing copyright interests, and legal interventions, such as antitrust actions, were seen as mechanisms for sustaining the subtle nexus between economics and citizenship. More was at stake than merely setting incentives for innovation.

While our contention over the scope of intellectual property rights often divides neatly into two separate conversations - of law and economics and of civil society, with little connection between them-the New Deal debate mixed both issues under a philosophically and socially robust definition of economic citizenship. Struggles, especially in the 1930s, over standards of living, prices, and the availability and quality of goods sold placed consumption at the center of public discourse. During this period, the American people "came to equate the consumer with the citizen, a consumer standard of living with democracy, and the full participation in such an economy of spending and accumulation with being an American." ${ }^{30}$ Surprisingly, the historical debates over the political economy of citizenship and the legal debates over the scope of intellectual property have been treated as distinct and hermetic.

Perhaps we can learn something from the rich, intertwined debates of the New Deal as we probe their contemporary normative implications. Although the idea of

29. Pierre Bourdieu, Distinction: A SOCIAL CRITIQUE Of THE JUdGMENT OF TASTE 7 (1984) (cultural consumption is "predisposed, consciously and deliberately or not, to [fulfill] a social function of legitimating social differences").

30. Charles McGovern, Consumption and Citizenship in the United States, 1900-1940, in GeTting AND SPENDING: EUROPEAN AND AMERICAN CONSUMER SOCIETIES IN THE TWENTIETH CENTURY 37, 37 (Susan Strasser et. al eds., 1998). 
intellectual property as an economic engine in national and international markets, as a valuable form of intangible property, and as a vehicle for social and political discourse has been important in our own time, we have been less successful at bridging economic and cultural imperatives.

\section{INTELLECTUAL PROPERTY AND THE PROBLEM OF MONOPOLY}

From the 1890s to the beginning of World War I, the United States experienced prodigious economic growth. The emergence of mature industrial capitalism brought with it a sharpening of social conflict and demands for limitations on property rights. During the course of the Progressive Era, there were several responses to this change-moral anxieties; paternalistic legislation for workers, children, and women; the rough foundations of public welfare administration; the search for a more rational social order guided by experts; and the promulgation of antitrust legislation. A loose coalition of southern and midwestern farming interests, nascent labor organizations, small businessmen, and urban reformers emerged - all of whom saw government regulation as a counter-balance to the increasing concentration of industrial power. By 1904, 318 trusts with capital of more than $\$ 7$ billion controlled $40 \%$ of American manufacturing. Numerous trusts were created through mergers. From 1895 to 1904,157 holding companies absorbed more than 1,800 firms. Consolidation especially affected capital goods combines such as coal, iron, steel, and oil. Beginning with the transportation revolution precipitated by the railroad, new mass markets emerged and new technologies of manufacture flourished in economies of scale.

\section{A. Progressive Era Legacies}

By the turn of the century, the vast majority of American states had responded to this concentration of wealth by adopting some form of antitrust legislation and had asserted regulatory authority over specific corporate forms such as railroads. The Interstate Commerce Act (1887) and the Sherman Anti-Trust Act (1890) established federal regulatory authority aimed at limiting the power of cartels. ${ }^{31}$ More than simply violating the natural laws of the market, industrial cartels threatened the autonomous role of the citizen by precluding his ability to act as an independent producer, instead treating him as a creature of powerful industrial combinations.

With rapid industrialization from the 1880s onwards, more Americans lost control of their productive lives and became dependent upon those who controlled the means of production for wages and the conditions of their workplaces. Progressives recognized that industrial liberty meant both freedom from oppressive government regulation and freedom from the mastery of private entities within markets. The definition of market power was not always rigorously parsed. It was often identified with the negative effects of the rise of an industrial economy of

31. Robert Bork, Legislative Intent and the Policy of the Sherman Act, 9 J.L. \& ECON. 7, 11 (1966). 
scale, including the emergence of impersonal corporate relationships, the decline of a self-employed quasi-autonomous middle class, and the willingness of corporate entities to exercise power without regard to personal or social costs.

Progressive Era jurists saw intellectual property through the optic of antitrust. As one court stated, "Patents, copyrights, and trade-marks excite two deeply seated feelings. One is the feeling of anyone who has originated anything of his right to claim an exclusive property in it and to the trade growing out of it. The other is a hatred of monopoly."32 With great difficulty, late nineteenth and early twentiethcentury courts balanced the competing demands of anti-competition law with intellectual property's exclusive rights. Patent law set the boundary between permissible and impermissible uses according to the extent to which market power was extended beyond the patent itself. In Motion Picture Patents Co. v. Universal Film Mfg. Co., for example, the Court struck down a restriction as part of the license on a film projector that went beyond the scope of the patent. ${ }^{33}$ Raising the specter of monopoly, the Court stated that an additional restriction "would give to the plaintiff such a potential power for evil over an industry which must be recognized as an important element in the amusement life of the nation."34 The public interest, the Court concluded, "is more a favorite of the law than is the promotion of private fortunes." ${ }^{35}$ As we shall see, similar Progressive Era attitudes about antitrust animated copyright and trademark law.

\section{B. New Deal Ambivalence}

When Franklin Roosevelt took office in 1933, the economy was in shambles. Virtually every economic sector was hobbled, and early his first term, major crises struck the agricultural and banking sectors. Industrial output was the source of particular concern. From the stock market crash of 1929 to the trough of the Depression in 1932, wages nose-dived by over 60 percent. ${ }^{36}$ Under-production meant the loss of jobs while the unemployment rate hovered around a quarter of the working population in $1933{ }^{37}$ The steel industry was running at 11 percent of capacity. ${ }^{38}$ This economic malaise fueled social unrest-exemplified by marches, rent strikes, taxpayer revolts, and farm holidays. Some pockets of the economy, defined by either industry or geography, were especially desperate. Rural and

32. Loughran v. Quaker City Chocolate \& Confectionary Co., 286 F. 694, 697 (3d Cir. 1924). While the relationship between antitrust and intellectual property law was drawn largely during the Progressive Era, it has been suggested that the Constitutional provision granting rights for patent and copyright was created with the idea of limiting monopolies, see Tyler T. Ochoa and Mark Rose, The Anti-Monopoly Origins of the Patent and Copyright Clause, 84 J. PAT. \& TRADEMARK OFF. SOC'Y 909 (2002).

33. 243 U.S. 502 (1917).

34. Id. at 519 .

35. Id.

36. Colin Gordon, New Deals: Business, Labor AND Politics In AMERICA 1920-1935160 (1994).

37. Id.

38. Louis H. Keyserling, The New Deal and its Current Significance in Re National Economic and Social Policy, 59 WASH. L. REV. 795, 797 (1984). 
urban despair led to a drifting population of over two million by 1933, a vast migrant swell of agricultural and industrial workers and their families, all in search of economic security. ${ }^{39}$

New Deal policy makers identified excessive competition as the most pressing economic problem. Cutthroat competition fueled a deflationary spiral. Companies with high fixed costs and excess capacity dumped goods on the market and further drove down prices. Lower prices led to a vicious cycle whereby businesses downsized their number of employees and lowered salaries. Increased unemployment itself depressed wages. Less money in consumer pockets, of course, dampened purchasing of durable goods which, in turn, fueled the deflationary cycle. Both businesses and ordinary citizens needed security and less competition. ${ }^{40}$

The Progressive fixation on antitrust seemed misplaced. Equally troubling was the idea that small economic units-once seen as the grounding for participatory democracy - could be harnessed efficiently to meet the economic crisis. Various alternative approaches were proposed. In 1932, William Kay Wallace, a retired diplomat, wrote Our Obsolete Constitution, arguing that a pre-industrial, eighteenth-century Constitution could not keep pace with the country's new needs for a constitution written around economic values. He suggested the government should deal with economic forces as corporate groups and embark on a new system of scientific capitalism in order to create a planned and more efficient national industrial economy. The only likely alternative, he warned, would be armed revolution. ${ }^{41}$ A year later, Rexford Tugwell's Industrial Discipline and the Governmental Art went one step further and, as a canonical work for the Roosevelt brain trust, tried to free the new administration from Justice Brandeis's curse of bigness. Arguing against "a constant disharmony of purpose," he proposed that the government should not just regulate particular economic sectors, but should also establish an over-arching plan for economic development. ${ }^{42}$

The New Deal had an ambivalent approach to antitrust. For some, the comeuppance of big business in the Great Depression suggested that governments should use this moment of vulnerability to penalize large combinations and breakup trusts with renewed vigor. For others, who believed that the old gospel of antitrust was an anachronism, the traditional Progressive critique of monopoly power lost some of its allure. In this alternative vision, the appearance of concentrated economic power was seen as the inevitable result of industrial mass production. These two conflicting viewpoints led to contradictions in New Deal policy. Justice Robert Jackson, a Roosevelt insider, best summed up the ambiguities of the President's own position on antitrust when he said Roosevelt "knew that there were

39. GORDON, supra note 36, at 160; MARK H. LEFF, THE LIMITS OF SYMBOLIC REFORM: THE NEW DEAL AND TAXATION 1933-1939 2-8 (1984).

40. Theda Skocpol and Kenneth Finegold, State Capacity and Economic Intervention in the Early New Deal, 97 PoL SCI. Q. 255 (1982) (describing the New Deal shift away from the competitive ideal).

41. William Kay Wallace, OUR OBSOLETE CONSTITUTION 115-154 (1932).

42. REXFORD G. TUGWELL, THE INDUSTRIAL DISCIPLINE AND THE GOVERNMENTAL ARTS 3-7, 189-219(1933). 
evils in the suppression of competition and that there were evils in competition itself, and where the greater evils were he never fully decided." ${ }^{43}$ Almost everyone could agree, however, that society needed stricter regulation of corporations - selfgovernance tempered with systematic federal guidelines-which would curb the worst of corporate abuses. ${ }^{44}$

Much of the New Deal's legislation in the first hundred days of the Roosevelt administration entailed displacing the Progressive Era idea of competitive markets policed through antitrust with government-sponsored cooperation between business and labor. The early New Deal sought to restrain untrammeled competition, not to foster more competition. In the National Recovery Administration, as will be discussed below, the New Deal promoted industry-wide cartels. However, the Roosevelt recession of 1937-1938 convinced some members of the New Deal brain trust that large business combines were intentionally pushing the economy downward by laying off workers and limiting the extension of capital. Roosevelt himself ordered an FBI investigation into what he called a "capital strike."45 Again, monopolies were at the center of political debate. Justice Louis Brandeis's approach to antitrust, which had never completely lost support, resurfaced. Roosevelt's acceptance of some old Progressive arguments led to his April 29, 1938 message to Congress in which he proposed the Temporary National Economic Committee (TNEC), which was intended to make recommendations to Congress on the regulation of competitiveness. TNEC soon became a bastion of antitrust sentiment. ${ }^{46}$

Intellectual property, as we shall see, had a special place in the New Deal economic constellation. Copyright was identified with successful new mass media industries-radio and motion pictures - which might prod the economy as a whole. By the mid-1930s, the large film studios established their dominance in the industry. Courts were reluctant to enforce antitrust laws that might loosen the grip of the studios over distribution. ${ }^{47}$ Trademarks, which were said to stimulate consumer purchases, also had a privileged place in the New Deal economy. "In an era when the consumer is beleaguered by a host of commodities of whose production he can know nothing," trademarks were viewed as providing the roadmap for a consumer economy. ${ }^{48}$ New Deal intellectual property policy reaffirmed what historian David Potter has called "American faith in plenty." 49

43. ROBERT H. JACKSON, THAT MAN: AN INSIDER'S PORTRAIT OF FRANKLIN D. ROOSEVELT 124 (2003).

44. Ellis W. Hawley, The New Deal and the Problem of Monopoly: A Study in ECONOMIC AMBIVALENCE 9-15 (1966).

45. David M. Kennedy, Freedom From Fear: The American People in Depression and WAR, 1929-1945 350-54 (1999).

46. William H. Page, Legal Realism and the Shaping of Modern Antitrust, 44 EMORY L.J. 1, 1819 (1995); KENNEDY, supra note 45, at 359-60.

47. Morton Kellner, Regulating a new Economy: Public Policy and economic CHANGE IN AMERICA, 1900-1933 76-85 (1990).

48. Sigmund Timberg, Trade-Marks, Monopoly, and the Restraint of Competition, 14 LAW \& CONTEMP. PROBS. 323, 323 (1949).

49. David M. Potter, People of Plenty: ECONOMic ABUndance and the AMerican CHARACTER 120 (1954). 


\section{TRADEMARKS, CONSUMER PSYCHOLOGY, AND THE PAX KEYNESIANA}

Trademark law was originally based on a fairly narrow common law action of palming off. As the New Deal approached, a major theoretical retooling of trademark law was required to establish a framework for a complex national market of mass produced consumer goods. This section describes the shift away from Progressive era trademarks with its requirement for a showing of fraudulent unfair competition and its traditional focus upon direct competition within the same market. Trademark law emerged from the New Deal as a much more robust area of legal doctrine, not simply because of the passage of the Lanham Act and the creation of a more consequential federal regime, but also because the very nature of trademark doctrine was transformed.

Nowhere could this be seen more clearly than in the Felix Cohen's 1935 canonical legal realist essay, Transcendental Nonsense and the Functional Approach. Cohen offered trademark law as an example of doctrine rapidly in flux, "trapezing around in cycles and epicycles without coming to rest on the floor of verifiable fact." According to Cohen, trademark doctrine was once predicated upon attempts to protect consumers against fraud. Increasingly, he argued, courts had departed from this grounding and embarked upon the transformation of trademarks into a form of property. Cohen described this doctrinal shift - which we shall see was promoted by Frank Schechter-as circular. It protects as property only property which indeed would not exist if it was not created by law: "One who by the ingenuity of his advertising or the quality of his product has induced consumer responsiveness to a particular name, symbol, form of packaging, etc., has thereby created a thing of value; a thing of value is property; the creator of property is entitled to protection against third parties who seek to deprive him of his property." 50

For Cohen, the idea that trademark was undergoing "thingification" was significant because it showed that even in his own day legal fictions divorced from "questions of social fact and ethical value" were being created. ${ }^{51}$ Although Cohen accurately noted the remarkable transformation of trademark doctrine, he wrongly identified the emergence of the concept of good will as unencumbered by social reality. Indeed, as I will show, the expansion of trademark law was part of New Deal economic and social policy intended to create a robust consumer market where products were differentiated through advertising. New Deal trademark law

50. Cohen, supra note 17 , at 814 . This article is one of only four sources published prior to 1940 on Fred Shapiro's list of most-cited law review articles. Fred R. Shapiro, The Most-Cited Law Review Articles, 73 Cal. L. Rev. 1540 (1985). See also Dalia TsuK MitCHell, ARCHITECT Of Justice: FeliX S. Cohen ANd the Founding of American Legal Pluralism 117-129 (2009) (describing legal realist debates shaping the article).

51. Cohen, supra note 17, at 809, 814-15; see also Zechariah Chafee, Jr., Unfair Competition, 53 HARV. L. REV. 1289, 1303 (1940) (questioning expansion of unfair competition so "all competition is prima facie tortuous [sic]"); Robert G. Bone, Hunting Goodwill: A History of the Concept of Goodwill in Trademark Law, B.U. L. REV. 547, 585-92 (2006) (describing legal realist attacks against emerging protections of business reputation). 
was not "simply economic prejudice masquerading in the cloak of legal logic." To the contrary, it was firmly rooted in political economy, using the legal mechanisms of market regulation to reflect psychological attachment to goods and to construct markets where goods were neatly distinguished from one another. There was a strong sense that the economic well-being of the country depended upon establishing a better-developed form of trademark law.

Nevertheless, within the realm of economic policy, trademark law faced its own contradictions. Trademarks garnered suspicion because product differentiation might create leverage for anti-competitive market behavior. With the advent of the New Deal, however, trademarks were valorized as powerful instruments of economic stimulation which might boost a slumping economy. Escaping the territorial conception of individual markets, New Deal lawyers saw trademarks as residing in the minds of consumers. This conceptual focus on the psychological and social uses of marks, which as we shall see was promoted by Frank Schechter, turned the attention of trademark doctrine away from unfair competition and into the realm of marketing.

This section describes the transformation of trademark law from tort to property rights in market reputation. While trademark was originally a mechanism to prevent palming off, by the 1920 s it was increasingly seen as the repository of goodwill, an investment in business reputation protected against misappropriation through legal recognition of proprietary interests. ${ }^{52}$ Influenced by behavioral psychology and anthropology, New Deal legal thinkers focused on the symbolic meanings of trademarks. Marks became instruments of persuasion, giving a broader public purpose. Concerns with the anti-competitive aspects of product differentiation were shunted aside.

The New Deal embraced trademark as a form of persuasion, which might stimulate consumer spending and provide badly needed prodding for the economy as a whole. Branding, moreover, allowed for the creation of a consumers' republic with the growing power of trademark identification. By the time of the New Deal, the country was awash in trade symbols. Advertising, consumer goods packaging, chain stores, and new forms of credit were all part of what I call the pax keynesiana. A nascent political economy, with promises of social peace, was predicated upon the expansion of consumer markets. Product identity was itself commodified. Property, psychology, and political economy formed the triptych upon which the New Deal's Lanham Act rested.

\section{A. Product Differentiation and Monopoly}

Perhaps nothing suggested how the specter of monopoly haunted early twentieth-century trademark law more than the repeated denial of this fact. For instance, in 1918 Justice Mahlon Pitney stated: "In truth, a trade-mark confers no

52. Bone, supra note 51, at 547. Goodwill was part of a larger shift to reputational concerns for U.S. corporations as the corporation, in the wake of Santa Clara County v. S. Pac. R. Co., 118 U.S. 394 (1886), increasingly saw itself as a distinct entity. See generally MARCHAND, CREATING THE CORPORATE SOUL, supra note 22. 
monopoly whatever in a proper sense, but is merely a convenient means for facilitating the protection of one's good-will in trade by placing a distinguishing mark or symbol-a commercial signature-upon the merchandise or the package in which it is sold." 53 Furthermore, he wrote, "There is no such thing as property in a trade-mark except as a right appurtenant to an established business or trade in connection with which the mark is employed." property in gross. They were boundary stones that marked the existence of goodwill. Goodwill, the traditional term for the inclination to go back where one has been well treated, was simply trumpeted by the mark itself. ${ }^{55}$

However, as Judge Learned Hand wrote, " [a] trademark is indeed often spoken of as a monopoly." 56 The fear was that a symbolic monopoly might lead to a monopoly of manufacture. ${ }^{57}$ Among intellectual property regimes, this identification of trademark with monopoly was especially troubling. Trademark lacked the Constitutional imprimatur of the Copyright and Patent clause that formed the basis for the limited monopolies of those regimes. Indeed, the Supreme Court in the Trade-Mark Cases explicitly denied the identification of trademarks with intellectual property regimes such as copyright and patent, which protected inventions and discoveries in the sciences, and with the writings of authors. ${ }^{58}$ The exclusive right to a mark seemed a form of exclusivity as real as those of patent law - but without the claim to inventiveness that warrants the granting of such a patent monopoly. A trademark was simply a creature of commerce.

While copyright might have benefited from the political advantages of being identified with the interests of struggling authors in their literary grub street or aspiring artists in attic ateliers, and patent valorized the tireless lone inventor, trademark was a benefit conferred upon businesses. Trademarks appeal not to those who appreciate science, literature, and the useful arts, but to the acquisitive instincts of consumers. Trademarks, it was said, threatened to establish ownership in language-and the English language was the common inheritance of all its speakers. ${ }^{59}$ Despite all these reasons why trademarks might be disfavored as a monopoly, trademarks are not limited in term, but are perpetual insofar as they are continually used in commerce.

Edward Chamberlin's The Theory of Monopolistic Competition (1935) pursued the argument that exclusive trademark rights should be seen as a form of

53. United Drug Co. v. Theodore Rectanus Co., 248 U.S. 90,98 (1918).

54. Id. at 97 .

55. Cruttwell v. Lye, 34 Eng. Rep. 129, 134 (1810) ("goodwill is nothing more than the probability, that the old customers will resort to the old place").

56. Artype, Inc. v. Zappulla, 228 F.2d 695, 696 (2d Cir. 1956).

57. Timburg, supra note 48, at 327; Ralph Brown, Advertising and the Public Interest: Legal Protection of Trade Symbols, 57 YALE L.J. 1165 (1948); Daniel M. McClure, Trademarks and Unfair Competition: A Critical History of Legal Thought, 69 TRADEMARK REP. 305 (1979).

58. 100 U.S. 82 (1879).

59. Milton Handler \& Charles Pickett, Trade-Marks and Trade Names-An Analysis and Synthesis, 30 COLUM. L. REV. 168, 178-80 (1930) (showing how limited the trademark monopoly is over language). See also Philco Corp. v. F. \& B. Mfg. Co., 170 F.2d 958 (7th Cir. 1948) (establishing right of defendant with similar name to radio-manufacturer Philco to use name in automotive repair since use of a personal name constitutes a property right). 
monopoly. ${ }^{60}$ A core function of trademarks was to isolate a product bearing a particular mark from a class of goods, which allowed the public to be convinced-a gullible public, no doubt-that other like products were not nearly as good. It is irrelevant whether this differentiation was based on real differences in quality among consumer goods or whether it was merely fanciful. In any event, trademark-based differentiation prevents imitation, and imitation is beneficial insofar as it eliminates monopoly elements. A perfect competitive market would exist where all goods were standardized, and there would be no basis for discrimination. Trademark creates an overlay on the goods themselves-and allows the use of selling methods that play upon the buyer's vulnerabilities. ${ }^{61}$

Trademark law was traditionally seen as a form of market regulation. Within the ambit of its common law origins, trademark had a limited function - to protect the maker of goods against diversion by means of deceit at the hands of competitors. The very idea that there are competitors implies that these are competitors within a single market. ${ }^{62}$ Accordingly, the 1905 Trademark Act restricted recovery in infringement cases to the sale of those goods which were "substantially of the same descriptive properties" as the registered mark bounded by a common market. ${ }^{63}$

\section{B. TERRITORIES OF THE MIND}

Territoriality established the extent of trademark legal protection. The Supreme Court examined the relationship of trademarks and markets in a 1915 case, Hanover Star Milling Company v. Metcalf. ${ }^{64}$ An Illinois company, Hanover Star Milling sold flour in Alabama and other southern states under the name "Tea Rose," establishing a reputation in those states. Metcalf served as an agent for another flour company which also marketed in good faith its flour under the "Tea Rose" mark, but was a more recent entrant into the southeastern American market. Neither company filed for state or federal registration of the trademarks, yet each asserted trademark infringement by their rival. The standard rule for granting trademark rights is to favor the first-in-time holder of the mark. But in this case, since the companies originally operated within wholly separate markets before one expanded into the other's market, the Court deemed the question of prior appropriation legally irrelevant and denied injunctive relief..$^{65}$

How do we define the term market? The Supreme Court in Hanover Star Milling struggled with this question. According to the Court, trademark owners held exclusive rights to their marks in order to protect the goodwill accrued. Trademark law did not grant property rights in signs or symbols, but instead

60. EDWARD CHAMBERLIN, THE THEORY OF MONOPOLISTIC COMPETITION 58 (1933).

61. Id. at 56-70.

62. EDWARD S. ROGERS, GOODWILl, TRADEMARKS, AND UNFAIR TRADING 50-52 (1914).

63. Trade-Mark Act of 1905 , ch. 592, \& 16, 33 Stat. 724 (1905).

64. 240 U.S. 403 (1916); see also generally Thomas F. Cotter, Owning What Doesn't Exist, Where it Doesn't Exist: Rethinking Two Doctrines from the Common Law of Trademarks, 1995 U. ILL. L. REV. 487 (1995).

65. Hanover Star Milling, 240 U.S. at 415. 
recognized relational rights within specific markets where consumers identified products through their reputations. These markets were not fixed, but dynamic. Any theory of trademark doctrine recognizing the right of trademark holders to employ a mark within a given local market must be aware that markets might expand and that ultimately companies with identical or nearly identical marks would likely find themselves in direct competition. As seen in Hanover Star Milling's most important immediate successor case, Sweet Sixteen Co. v. Sweet "16" Shop, Inc., the senior user's probable course of geographic expansion is relevant in determining competing rights of trademark owners in remote markets. ${ }^{66}$

Hanover Star Milling reflects the shift to larger markets. Prior to the $1880 \mathrm{~s}$, the United States was a largely agrarian economy, and most markets were regional. But by 1895 , major railroad lines were completed, and goods were traveling much further than before. Trademarks developed by good faith parties in local markets would have no legal remedy when encountering similar marks in a distant market. The Tea Rose doctrine, as the Hanover Star Milling holding came to be known, was soon enlarged to protect marks within a natural zone of expansion, under which advertising, sales, and reputation would determine the nature of this amorphous market. Justice Holmes was troubled by the uncertainty of protecting trademarks through drawing fluid and ill-defined market boundaries, and in his concurrence in Hanover Star Milling, argued that each state's official borders encompassed a single market. ${ }^{67}$

The Tea Rose doctrine failed to provide fixed boundaries demarcating one market from another. The legal concept of the market itself was becoming increasingly amorphous, allowing for expansion to places where advertising and the search for more business would naturally lead. But it was also evident that even this flexibility was not enough. As Hanover Star Milling showed, businesses would inevitably press beyond the legal definition of market and collide with competitors. Justice Holmes' attempt to draw a sharp boundary at state lines provided more certitude, yet also, unsurprisingly, constituted an even more artificial demarcation of markets.

Before World War I, trademark doctrine held that the marks for two or more products had to be identical in order for there to be infringement. The Trademark Act of 1905, for example, required "merchandise of substantially the same descriptive properties," as the basis for an infringement suit. ${ }^{68}$ Moreover, as the Tea Rose doctrine suggests, these products had to share a market. Increasingly, however, courts began to realize that the problem was not the collision of marks in abstract markets, but in the very minds of consumers-where two similar marks might create confusion. In Aunt Jemima Mills Co. v. Rigney \& Co., the plaintiff used the mark AUNT JEMIMA on flour, while the defendant used it on syrup. ${ }^{69}$ Although these were arguably separate markets, there existed a likelihood that consumers might mistakenly believe both came from the same source, and

\footnotetext{
66. 15 F.2d 920 (8th Cir. 1926).

67. Hanover Star Milling, 240 U.S. at 424-26 (Holmes, J., concurring).

68. Trade-mark Act of 1905, ch. 592, 16, 33 Stat. 724, 728 (1905).

69. 247 F. 407 (2d Cir. 1917), cert. denied, 245 U.S. 672 (1918).
} 
therefore the Second Circuit enjoined the use of the defendant's mark. This case is significant for establishing what has been called the Aunt Jemina Doctrine, otherwise known as the unrelated goods doctrine, which established interests for the trademark holder when (1) the owner's reputation may be damaged in the mind of his customers and (2) the owner may at some time in the future wish to extend his business into the market which the second user has begun to exploit.

It does appear that the idea of expanding trademark beyond the absolute limits of the market which it currently inhabits was a controversial idea. ${ }^{70}$ Extension into another market, even a closely related market, raised the specter of legal protection for monopoly, a kind of reaching beyond the immediacy of the mark. Clearly, in order to side-step the idea of control of a market, the unit for a trademark had to shift from the market, narrowly defined, to the mind of the consumer.

The shift from a market-a locus of exchange where identification is situated within the realm of geography - to the mind suggests a new-found awareness of the psychological power of trademarks. This fascination with the psychology of trademarks most clearly occurs in the work of Frank Schechter, the brilliant and iconoclastic trademark attorney who, though he died at age forty-seven, serves as the éminence grise behind so many of the New Deal changes in trademark law. His two major works, the path breaking 1926 article The Rational Basis of Trade-Mark Protection and a 1925 book entitled Historical Foundations of Trade-Mark Law, redefined the terrain of trademarks, and might be said to have shaped the intellectual underpinnings of the Lanham Act. ${ }^{71}$

Little biographical examination hitherto has been made of Schechter's role. But it is important to note that he envisioned trademark and unfair competition as key components in establishing norms of commercial morality, whereby even outsiders to traditional territorial markets would be obligated to treat competitors and consumers fairly. ${ }^{72}$ Schechter was an idealist. To his great disappointment, after returning from World War I military service as an intelligence officer in Germany, Schechter found widespread, unfair trade practices. ${ }^{73}$ This may have been a

70. See, e.g., Judge Leamed Hand's waming in a subsequent case against the injustice of permitting too broad a power of the owner to establish a "premonitory lien upon a future market." According to Judge Hand, this would constitute reaching "a choking hand into a market not its own." S.C. Johnson \& Son, Inc. v. Johnson, 175 F.2d 176, 180 (2d Cir. 1949).

71. Frank I. Schechter, The Rational Basis of Trade-Mark Protection, 40 HARV. L. REV. 813 (1927) [hereinafter Schechter, Rational Basis]. See also Edward S. Rogers, The Unwary Purchaser, 8 MICH. L. REV. 613, 622 (1910) (an earlier call to incorporate psychological insights into trademark litigation).

72. Schechter enlisted after the sinking of the Lusitania. His wartime experiences as a military officer during the occupation of Germany are recounted in a New York Times article which he authored, entitled Army of Occupation, Binsfeld: Commentaries of a Lieutenant, A.E.F., Who Ruled Twenty-One German Villages with an Armed Force of One Orderly, N.Y. TIMES, Aug. 31, 1919, at 65.

73. Schechter was embedded in a Jewish social network and involved with Jewish issues. As I argue throughout this section, such ethnic commitments significantly shaped his legal thinking in trademark law. He was a practicing attorney in the New York law firm of Stroock \& Stroock, which was identified with a notable German Jewish clientele. See the firm's own privately printed history, JETHRO K. LIEBERMAN, STROOCK \& STROOCK \& LAVAN: AN INFORMAL History OF THE EARLY YEARS 1876-1950, at 17 (1987). The links between the senior partner Sol M. Stroock, who wrote Schechter's obituary, and Schechter are not surprising. In 1930 Stroock, himself related to the 
particularly potent issue for Schechter because of sensitivities about how his coreligionists were perceived. Throughout the 1920 s, there were complaints that Jews were disproportionately represented in the area of white-collar crime. ${ }^{74}$ Perhaps in order to mask the particularly ethnic dimension of his concerns, Schechter phrased the problem as how the business culture might be shaped on the ground by legal culture. Quoting Harold Laski, he brusquely asked, "[c]an business be civilized?"75

In a revealing essay on primitive law, another one of his interests, Schechter suggested that economic rationality must be seen as a collective enterprise. ${ }^{76}$ The essay, which was intended to be part of a larger projected work on the history of trade morals and control, argued that a line could be drawn from Bronislaw Malinowski's system of reciprocity of gift exchange or potlatch to contemporary legal models for fair trade. Market exchange evokes depth-psychology as "the collision between self and others.".77

The self-proclaimed purpose of The Rational Basis of Trademark Protection was to push trademark law beyond its roots in the tort of palming off. Prior to the late 1830 s, trademark infringement actions were truly actions at law for deceit, and therefore fraudulent intent was a required element of proof. ${ }^{78}$ The rationale of fraud continued to animate trademark law through the beginning of the twentieth century. However, the Supreme Court, in the 1923 case A. Bourjois and Company, Inc. v. Katzel, shifted the terrain of trademark law from the tort of fraud to a property right. ${ }^{79}$ A French manufacturer of face powder had sold its United States portion of the business, including the registered trademark, to the plaintiffs. The plaintiffs continued the business, importing face powder from France and marketing the import with the same packaging as had been used previously. Finding that the rate of exchange was particularly favorable, the defendant, a French company returned to the United States market and sold face powder in similar boxes. While the label on the French face powder box read "Poudre de Riz

distinguished Hebrew scholar Abraham Berliner, was appointed chairman of the board of the Jewish Theological Seminary. Id. at 25. Schechter's indignation at unfair trade practices courses through the notes of his article, Trade Morals and Regulation: The American Scene, 6 FORDHAM L. REV. 190 (1937).

74. Henry L. Feingold, The Jewish People in America, a Time for Searching: Entering THE MAINSTREAM 48-53 (1992) (describing attempts by the Jewish community to address negative perceptions and their creation); see also ARTHUR A. GOREN, NEW YORK JEWS AND THE QUEST FOR COMMUNITY: THE KEHILLAH EXPERIMENT 1908-1922 59-60 (1970) (discussing the 1912 creation of the Bureau of Social Morals by the Jewish community in New York City).

75. Frank I. Schechter, A Study in Comparative Trade Morals and Control: Part I, 19 VA. L. REV. 794, 795 (1932-33).

76. Frank I. Schechter, The Law and Morals of Primitive Trade, in LEGAL ESSAYS IN TRIBUTE TO ORRIN KIP MCMURRAY 565, 565-622 (Max Radin \& A.M. Kidd eds., 1930).

77. Schechter's sustained interest in primitive and comparative law might also be seen in his review of Paul Vinogradoff's Collected Papers, Paul Vinogradoff-"The Pontiff of Comparative Jurisprudence", 24 ILL. L. REV. 528 (1929-30).

78. McClure, supra note 57, at 313; see also Millington v. Fox, 3 Myl \& Cr 338 (1838) (where an English court first did not require a showing of fraudulent intent in order to be granted an injunction for trademark infringement).

79. 260 U.S. 689 (1923). 
de Java," the United States product label read "Poudre Java." Both labels described the origins of the powder from Java. The French company was not seeking to palm off its goods as those of the United States importer. But the Court found that the French company infringed the American company's trademark. Upon selling its trademark, the French company also had transferred its goodwill to the American successor company. The Court's decision was based upon the idea that the property right in a trademark was not the mark itself, but the goodwill or business reputation embodied in the mark. ${ }^{80}$

The true function of the trademark therefore is "to identify a product as satisfactory and thereby to stimulate further purchases by the consuming public." ${ }^{.81}$ Trademarks do not merely serve as a symbolic marker for goodwill, but create goodwill, and therefore act as an engine to spur the economy. The trademark is a "creative 'silent salesman' through which direct contact between the owner of the mark and the consumer is obtained and maintained. ${ }^{82}$ Schechter wrote of the power of trademarks to "reach over the shoulder of the retailer" and speak directly to the consumer. ${ }^{83}$ There is, in Schechter's words, "a psychological hold on the public." 84

Schechter's analysis alleviated some of the anxieties over trademark's relationship to monopoly. While markets may be subject to monopoly, according to Schechter, the minds of individuals were not. Marks were meant as communicative instruments-elements of persuasion, not anti-competitive elements of coercion. In the words of another New Deal trademark scholar, "trademarks, indeed, are the essence of competition because they make possible a choice between competing articles by enabling the buyer to distinguish one from the other. ${ }^{.85}$ The commercial marketplace became a cerebral marketplace of psychological impressions.

\section{TRADEMARK AND THE BIRTH OF THE CONSUMER REPUBLIC}

The psychological thrust of Schechter's work stood firmly within the emerging social sciences at the beginning of the twentieth century, which envisioned consumption as a response to psychological and social pulls. Thorston Veblen's The Theory of the Leisure Class famously describes habits of conspicuous consumption-which, he argues, exist to establish an individual's place in society. ${ }^{86}$

80. Schechter saw this decision as a turning point in establishing a property right in goodwill. See Frank I. Schechter, Trade Morals and Regulation: The American Scene, 6 FORDHAM L. REV. 190 (1937). Schechter had argued for this analysis, finding a property right in trademarks in an earlier case, Jantzen Knitting Mills v. A. Balmuth, Inc., 257 N.Y.S. 611 (N.Y. App. Div. 1931).

81. Schechter, Rational Basis, supra note 71, at 818.

82. Frank I. Schechter, Fog and Fiction in Trade-Mark Protection, 36 CoLUM. L. REv. 60, 65 (1936) [hereinafter Schechter, Fog and Fiction].

83. Schechter, Rational Basis, supra note 71, at 818; 22 TRADEMARK BULL. 139 (1927), reprinted in 60 TRADEMARK REP. 334 (1970).

84. Schechter, Rational Basis, supra note 71, at 831.

85. Edward S. Rogers, The Lanham Act and the Social Function of Trade-Marks, 14 LAW \& CONTEMP. PROBS. 173, 182 (1949).

86. THORSTEN Veblen, THE THEORY OF the Leisure Class: AN ECONOMIC STUdy of INSTITUTIONS 35-9 (1899). 
A throwback to a predatory past, this thirst to acquire consumer goods paralleled the acquisitive underpinnings of barbarian warfare. Veblen's fin-de-siècle book, bitingly satiric and darkly pessimistic about contemporary American society, portrayed advertising as purely parasitic. But Schechter deftly turned this notion on its head: advertising was stimulation, not manipulation. The amount of information from marketing might be endless-and there was virtually no limit on the real estate of mental images of products.

Both Schechter's rational theory of trademark and the Lanham Act itself fit neatly within a new definition of democracy that was emerging around the turn of the century and came to fruition with the New Deal. Self-fulfillment was privileged over a broader understanding of civic life within what has been called "the consumers' republic" or the "democratization of desire." 87 American modes of consumption fostered a culture where much of the psychological life of individuals was lived through the choice of goods. A fair amount of social criticism has been leveled at the increasingly consumer-driven aspirations of early twentieth-century Americans. However, it is important to keep in mind that trademarks provided not simply a focus on consumer goods, but a sophisticated language of cultural identity. Trademarks fit neatly into the modernist enterprise of simultaneously allowing the construction of a more unified culture and allowing the splintering of this culture into a myriad of separate, self-fashioned identities.

Consumer goods fashioned the creation of a new social order. Certain employers, such as Henry Ford, saw mass consumption as integrating workers within a framework of middle-class culture, and even promoted the idea of increasing workers' purchasing power and leisure time. The link between scientific management with its increased productivity and mass consumption was the cornerstone of the business lobby called the Twentieth Century Fund, which included Henry Dennison and Edward Filene. For this group of reformers, business should foster mass consumption through high wages and low prices as a form of redistribution of wealth. Filene thought of mass consumption as the United States version of mass socialism. ${ }^{88}$ Consumption would establish ties of loyalty towards both the employer and society as a whole. The hope, too, was that ordinary people would become more refined. Working people, in short, were encouraged to buy into the middle class. ${ }^{89}$ By the turn of the century, a vastly enlarged postal service, the spread of chain stores, a credit revolution that allowed payment for durables by installment plan, and the rise of a sophisticated advertising industry all signaled the birth of the consumer republic.

The United States Postal Service underwent a massive expansion after 1900. Although after 1861, urban residents enjoyed mail delivery to dwellings, rural citizens had to pick up their mail in town. Moreover, parcels were delivered by six

87. LEACH, LAND OF DESIRE, supra note 22, at 8.

88. JACOBS, POCKETBOOK POLITICS, supra note 22, at 49-51.

89. STEVEN FRAZER, LABOR WILl RULE: SidNEY HILLMAN AND THE RISE OF AMERICAN LABOR

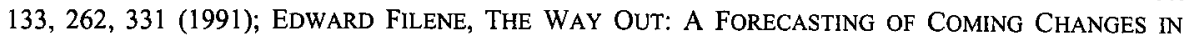
BUSINESS AND INDUSTRY (1924); LIZABETH COHEN, MAKING A NEW DEAL: INDUSTRIAL WORKERS IN CHICAGo 1919-1939 100 (1990) [hereinafter COHEN, MAKING A NEW DEAL]. 
large express companies, which commanded high rates, and, again, did not provide adequate service to the countryside. Between 1898 and 1920, however, the Federal government expanded its role to rural delivery and parcel delivery. Department Store magnate John Wanamaker, clearly vested in a more efficient means of delivering consumer goods, served as Postmaster General from 1889-1893, and was a critical figure in this expansion. Not everyone welcomed the expansion of the Postal Service. While the Grange and large stores pushed for more service, small-town shopkeepers and parcel companies feared change would destroy their businesses.

With the support of Sears, Roebuck and Montgomery Ward, as well as prominent department stores such as Macy's and B. Altman, backers of expansion in 1902 organized to form the Postal Progress League. In 1897, there were only 82 postal routes in the country. In 1905, however, Congress provided for routes at requests delivered through Congressmen, and more than 32,000 routes were opened that year alone. Less than a decade later, in 1912, Congress created the national parcel post system. Mail order business grew exponentially. In 1908 there was $\$ 40$ million in profits. By 1920 , this figure had risen to $\$ 250$ million in profits. ${ }^{90}$

Mail order companies and large department stores depended upon the burgeoning Postal Service. By the 1920s, however, chain stores, such as the Great Atlantic and Pacific Tea Company, more commonly known as A \& P, brought mass selling directly to small towns across the United States. The 1920 s was a decade of remarkable growth for chain stores. They increased their share of national retail sales from $4 \%$ to $20 \%$. Chain stores engaged in all sorts of retail merchandising, including the sale of household appliances, clothing, and restaurants. A strong stock market provided the financing for chain store expansion. Led by A \& P, chain stores comprised $40 \%$ of the total national grocery sales. ${ }^{91}$ Smaller dry goods or grocery stores had often sold bulk, unmarked, or local groceries and goods. At the turn of the century, most Americans still bought various basic commodities, such as sugar, molasses, flour, rice, and nails, out of barrels or tins. ${ }^{92}$ Personal interactions - face-to-face encounters between local sellers and local purchasers-established the quality of goods.

Chain stores, however, relied upon packaged products marked with clearly identified labels, which were provided by a network of middlemen, wholesalers and distributors operating across regions. Packaged products established a direct relationship between the producers-the source of the goods in trademark termsand consumers. The technology to create cardboard boxes and tin cans with stamped labels had already emerged by the $1880 \mathrm{~s}^{93}$ Concerned about competition to its mail-order business, Sears, Roebuck entered the chain store arena in 1925 . In less than five years, it would open over three hundred stores. Montgomery Ward's, its major mail-order competitor, was forced to counter Sears in the retail business

90. LEACH, LAND OF DESIRE, supra note 22, at 176-85.

91. Richard C. Schragger, The Anti-Chain Store Movement: Localist Ideology and the Remnants of the Progressive Constitution 1920-1940, 90 IOWA L. REV. 1011 (2005).

92. STRASSER, supra note 22, at 29-30.

93. Id. at 32 . 
as well..$^{94}$

Mass selling required mass production. Chain stores, which offered standardized brands, depended upon centralized management and economies of scale whereby purchases were made directly from manufactures and middlemen were sidestepped. Rapid turnover allowed chain stores to charge lower prices. These stores appreciated national branding and marketing which would stimulate consumer desire and, presumably, move goods off the shelves. By 1929, chain stores sold one-fifth of all retail goods and forty percent of all groceries. ${ }^{95}$ Concerned that these stores were undermining the viability of main street America, a number of states introduced special taxes aimed at chain stores during the late 1920 s and early 1930s.

New retail outlets led to greater reliance upon trademarks to provide a corporate personality, which, in the words of one leading designer of business logos, Raymond Lowey, must be "instantaneous" and "potent." Innovative economic thinking also led to different attitudes about consumer spending. Already in the late 1920s, Edwin Seligman turned upside down the old moralizing language against consumers purchasing on credit by suggesting that installment credit might be advantageous from both a personal and social point of view. It was not reckless or improvident to purchase even luxury goods using consumer credit. Instead, Seligman argued, it made sense that durable goods that were consumed over time should also be paid for over time. Moreover, the economy as a whole benefited from consumer activity that wards off the threat of over-production. ${ }^{97}$

Buying consumer durables on installment became the norm. Department stores created "installment clubs" in order to sell various durables, including phonographs, pianos, and sewing machines. ${ }^{98}$ By 1924, almost three-quarters of automobiles were brought on credit plans. In $1925,70 \%$ of furniture and $75 \%$ of radios were purchased on time. ${ }^{99}$ Increasingly, economists in the 1920 s became aware of the link between installment purchasing and labor discipline. ${ }^{100}$ The model worker would raise production in an attempt to boost wages and sustain a higher level of consumer purchases. Moreover, installment consumption made the specter of unemployment more risky. The threat of repossession, and the loss of the capital invested in consumer durables, meant that failure to sustain installment payments might have devastating affects on the working class family.

94. COHEN, MAKING A NEW DEAL, supra note 89, at 104-110.

95. Michael J. SANdel, Democracy's Discontent: America In SEARCh of a Public PHILOSOPHY 227 (1996).

96. Raymond Loewy, NeVER Leave Well ENough Alone 37 (1951)

97. LENDOL CALDER, FINANCING THE AMERICAN DREAM: A CULTURAL History OF CONSUMER CREdit 237-61 (1999); EdWIN R. A. SEligman, THE ECONOMICS OF INSTALlmENT SELling: A STUDY IN CONSUMER's CREDIT (1927). On Seligman, see Ajay K. Mehorta, Edwin R.A. Seligman and the Beginnings of the U.S. Income Tax, available at http://ssm.com/abstract $=925011$ (describing Seligman's commitment to German conceptions of scientific political economy).

98. LEACH, LAND OF DESIRE, supra note 22, at 127.

99. CROSS, supra note 22, at 29.

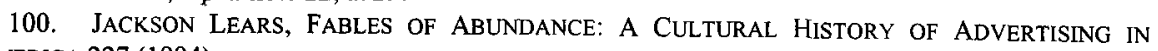
AMERICA 227 (1994). 
Evidence suggests that workers were wary of purchasing consumer goods on credit, and still often preferred to pay cash. When they did purchase through installment plans, workers chose less expensive products. ${ }^{101}$ The rush towards consumer credit in the $1920 \mathrm{~s}$ was largely a middle-class phenomenon. Nevertheless, the emergence of installment purchasing held out the vision of an ownership society where a wide range of consumer goods might be within the reach of ordinary people.

Whatever consumer goods were produced through new technologies and mass production, and whatever new modes of delivering goods existed-postal services, department and chain stores, and the credit instrument of installment plans-there was still the fundamental need for marketing to stimulate desires. Already by the early twentieth century, a revolution had taken place in marketing, which introduced both color and striking visual statements. Artemis Ward, an early guru of advertising urged companies to use colorful iconographic elements since such images created "imprints on the buying memory."102 Throughout the 1920s, advertising served up a broad array of consumer goods in a plethora of new forms. Cultivating desire was indeed a sign of cultivation. One member of the advertising business referred to the number of new products as an "index of civilization."103 More goods required ever more advertising to distinguish between them. If, as is so often argued, trademark serves to lower information costs, product differentiation through trademarks also contributed to creating the bewildering array of choices that required ever-larger amounts of consumer guidance.

With the end of the 1930s, however, advertising had lost much of its luster and itself badly needed better public relations. It was identified with extravagance and deception. Consumer advocates denounced the failure of advertising to provide fundamental information to consumers. The modern consumer movement emerged in the 1920s. In 1927, Frederick J. Schlink and Stuart Chase launched Your Money's Worth, which would later form the basis for the Consumers Union and Consumer Reports. ${ }^{104}$ Consumer advocates; social critics, such as José Ortega y Gassett, who published The Revolt of the Masses in 1930; intellectual elitists, such as H.L. Mencken and T.S. Eliot, who routinely tossed sharp barbs at the masses; and observers of emergent fascist societies grew increasingly uncomfortable with any manipulation of mass psychology. ${ }^{105}$ But these cultural critics, truly moral critics, of consumption, who identified advertising and packaging as instruments of arousal creating envy among working-class and emerging middle-class citizens, were increasingly marginalized as the century progressed. ${ }^{106}$

In the 1930s, advertising underwent rehabilitation. Consumer culture was identified with choice and democracy, as opposed to fascist and communist

101. COHEN, MAKING A NEW DEAL, supra note 89, at 106.

102. Artemas Ward, copy of the contract with the Interborough Rapid Transit Company (December 27, 1913), quoted in LEACH, LAND OF DESIRE, supra note 22, at 38-49.

103. MARCHAND, supra note 22, at 342.

104. LEARS, supra note 100 , at $240-41$.

105. Id. at 230-32; see also generally HOROWITZ, THE ANXIETIES OF INFLUENCE, supra note 22.

106. JACOBS, supra note 22, at 29. 
totalitarian regimes. It was a way of cabining class strife between workers and industrialists, as both shared a stake in the production of a broad array of consumer goods. ${ }^{107}$ Citizen-consumers would be stakeholders in society and foster social peace. Finally, as would be argued by New Deal economists, the consumer economy would help lift the United States out of its economic doldrums, promoting a more vigorous economy. The United States would therefore have the economic resources to confront the political dangers that loomed abroad.

Consumption was the key to the new economy. John Maynard Keynes sought to repeal one of the classic laws of market economics in the early twentieth century, Say's Law, which stated that supply and demand were ceaselessly in balance, and relied upon markets as self-correcting. Instead, Keynes argued that consumer spending was necessary to fuel a stagnant economy. Consumer spending might be prodded through changes in progressive tax policies that countered the concentration of wealth, programs of public works, investment in infrastructure or more available credit. Roosevelt adopted some of these approaches, establishing the Civilian Conservation Corps (CCC) and the Works Projects Administration (WPA) as work relief programs. In April 1938, the New Deal made Roosevelt's administration the first in American history to deliberately embark upon deficit spending for the purpose of economic stimulus.

Edward Filene, the Boston department store magnate, spoke of unleashing "long pent-up human impulses." He urged the shift from institutional advertising of goods to the idea of selling a vision of lifestyle - which might become the basis of a citizenry living at peace. ${ }^{108}$ Advertising had its gurus in the form of figures like Filene, Walter Pitkin, professor of marketing at the Columbia School of Journalism, and Edward Bernays, a nephew of Sigmund Freud and a founder of modern public relations. ${ }^{109}$ Bernays believed that it was possible to alter behavior through completely changing the norms of what was acceptable. Individuals believe that they are making autonomous purchasing decisions while unaware that "in actual fact his judgment is a mélange of impressions stamped on his mind by outside influences which unconsciously control his thought."110 Bernays used subliminal symbolic clues - as in the case of his campaign linking desirable slim figures to smoking in order to entice women to purchase cigarettes. The mix of psychology and marketing was dizzying. "The time to advertise is all the time,"

107. Of course, consumer goods which map social relations and serve to distinguish class have often, instead, become the locus of social struggle. See generally MARY DOUGLAS \& BARON ISHERWOOD, THE WORLD OF GOODS (1979); BOURDIEU, supra note 29.

108. EWEN, supra note 22, at 54-6.

109. LaRry TyE, THE Father of SpIN: EdWARD L. Bernays \& THE Birth of PubliC RELATIONS 8 (1998) (Bernays was twice-over related to Freud since his mother was Freud's sister and his father's sister was Freud's wife).

110. EDWARD L. BERnAYS, PROPAGANDA 49 (1928). Bernays' interest in human psychology was typical of a post-World War I interest in the mass psychology of manipulation as part of a larger project of explaining the outbreak of war. See, e.g., W. TROTTER, INSTINCTS OF THE HERD IN PEACE AND WAR (1916); EdWARd L. Bernays, CRystallizing PUblic Opinion (1923). For a discussion of New Deal tax policy and propaganda, see Carolyn C. Jones, Class Tax to Mass Tax: The Role of Propaganda in the Expansion of the Income Tax During World War II, 37 BUFF. L. REV. 685 (1989). 
stated John Wanamaker. ${ }^{111}$

Advertising was not merely a means for selling goods. Rather, it shaped the dominant aspirations of individuals-their desires and their affiliations. In a certain way, the shift to a consumer society represented a shift in ethnic politics as well. The New Deal was inclusive of ethnic Catholics from Southern and Eastern Europe and Jews. Ever expanding mass consumption promised access to economic equality without having to undertake the risk of redistributing existing wealth. ${ }^{12}$ The Protestant ethic of self-control and delayed gratification was supplanted by one reflecting the immediacy of plenitude. Most importantly, the consumer republic promised social peace. Already during the $1920 \mathrm{~s}$, concerned businessmen argued that consumption-oriented workers might demonstrate political loyalty towards the market economy. ${ }^{113}$ There was a lingering awareness of the social unrest of the end of the nineteenth century-the negative response to the austere workplace of factory production. Helen Woodward, the leading female advertising copywriter of the $1920 \mathrm{~s}$, spoke of consumer culture as the sublimation of more dangerous urges. ${ }^{114}$ With the New Deal, of course, this idea of a quid pro quo, whereby labor discipline was exchanged for higher wages and a broad array of consumer goods, would reach its climax.

Various strategies, such as public ownership of utilities and railroads, the building of subsidized housing for workers and a shift in currency policy, might have helped push the United States out of its economic slump. ${ }^{115}$ But government investment in infrastructure was limited by political considerations. In his wellcirculated open letter to Roosevelt, Keynes stated that individuals must "be induced to spend more out of their existing incomes." urged consumers in the midst of depression not to save-but to shop, and create, in his terms, the hydraulic for the economy. In the fall of 1933, General Hugh Johnson, the chief administrator for the NRA, launched a "Buy Now" campaign. ${ }^{17}$

Schechter's contribution to the pax keynesiana was to tell consumers to be ready for a firm tap on the shoulder from trademark's silent salesman. But this shift towards stimulating restless desire, of course, preceded both Schechter and the New Deal. Increasingly, packaged goods, with their silent salesmen, came to dominate American markets in the first three decades of the twentieth century. By 1907, A \& $P$ food stores only offered packaged goods. Advertising revenues increased thirteen-fold from $\$ 200$ million in 1900 to $\$ 2.6$ billion in $1930 .{ }^{118}$ New venues for

111. The Advertising World 22 (1917), quoted in LEACH, LAND OF DESIRE, supra note 22, at 43.

112. COHEN, CONSUMER'S REPUBLIC, supra note 26, at 127.

113. EWEN, supra note 22, at 57.

114. Id. at 85 .

115. David M. Kennedy, Freedom from Fear: The American People in Depression and WAR 1929-1945 357-60 (1999).

116. John Maynard Keynes, From Keynes to Roosevelt: Our Recovery Plan Assayed: the British Economist Writes an Open Letter to the President Finding Reasons, in Our Policies, for Both Hopes and Fears, N.Y. TIMES, Dec. 31, 1933, at XX2. See also Alan Sweezy, The Keynesians and Government Policy 1933-1939, 62 AM. ECON. REV., Mar.-May 1972, at 116-24 (Papers and Proceedings).

117. HAWLEY, supra note 44 , at 68 .

118. EWEN, supra note 22, at 62 . For a slightly different estimate, see CROSS, supra note 22, at 32. 
marketing appeared, such as billboards, subscription magazines, consumer catalogs, and radio. By 1905, there were nearly 10,000 registered trademarks. ${ }^{119}$

As a means of stimulating desire, advertising was bolstered by the emergence of behavioral psychology in the early decades of the twentieth century. John B. Watson, perhaps the most influential of the applied psychologists, argued that all human reactions-feelings, sensations, and thoughts-might be characterized within the paradigm of stimulus and response. Behavioral psychologists approached matters differently than earlier investigators into the workings of the mind by relying upon scientific methods. Often operating out of laboratories, they tested both human and animal subjects, and rigorously sought to purge themselves of moral categories. Some of these psychologists had worked with the Army during World War I as part of a larger project to sort new recruits into different categories according to their capabilities and to foster their adjustment to military life.

As I have argued, Schechter's rational theory of trademarks (an odd name for the belief that the mind should be constantly subject to a plethora of demands to consumers made by irrational desires, as well as rational choices) shifted trademark thinking away from the market to the mind, and therefore away from the problem of monopoly. If, as Schechter and other architects of New Deal trademark doctrine assumed, there was no problem with monopoly, then there was no problem with granting a larger bundle of trademark proprietary rights.

Schechter's second major contribution was his historical analysis, which became the basis for a call for greater property rights in trademarks. Justice Harlan Fiske Stone, then at Columbia Law School, had persuaded Schechter to take a leave from his practice, which Oliver Wendell Holmes, an admirer of Schechter's historical work, called "one of the great acts of [Stone's] life."120 Schechter's work on the historical origins of trademark emerged from his 1925 thesis on "The Historical Foundations of the Law Relating to Trade-Marks," which was written for completion of his Doctor of Jurisprudence degree, the first such degree granted by Columbia. ${ }^{121}$

Two important methodological innovations marked Schechter's historical work. First, he dug deeper in the past, finding much earlier development of trademarks. Schechter demonstrated how trademarks originated in their usage by medieval and early modern guilds, and not-as had been suggested - in the development of nineteenth-century unfair competition doctrine. This bolstered the notion of trademark as embodying the norms of commercial morality, and not simply

119. LEACH, LAND OF DESIRE, supra note 22, at 45-46.

120. Keith M. Stole, How Early did Anglo-American Trademark Law Begin? An Answer to Schechter's Conundrum, 88 TRADEMARK REP. 564, 565-566 n.8 (1998).

121. Frank Schechter, Lawyer, Dies at 47, N.Y. TIMES, Sept. 27, 1937, at 21; JULIUS GOEBEL, JR., FOUNDATION FOR RESEARCH IN LEGAL HISTORY, A HISTORY OF THE SCHOOL OF LAW COLUMBIA UNIVERSITY 296 (1955). On Schechter's career, see Sol M. Stroock, Memorial of Frank Isaac Schechter, 1938 Y.B. Ass'N OF THE B. OF THE CITY OF N.Y. 416-18. For historical works, see WILLIAM H. Browne, A Treatise on the LAw of Trademarks and ANalogous SuBJects1-14 (1885); Edward S. Rogers, Some Historical Matter Concerning Trade-Marks, 9 MICH. L. REV. 29 (1910); Abraham S. Greenberg, The Ancient Lineage of Trade-Marks, 33 J. PAT. \& TRADEMARK OFF. SOC'Y 876 (1951); Benjamin G. Paster, Trademarks-Their Early History, 59 TRADEMARK REP. 551 (1969). 
protecting against consumer fraud. Schechter, secondly, used sources very different than those employed by traditional legal scholars. He drew upon the records of guilds and merchants themselves. Some of the examples of his extraofficial documentation were notable. Schechter, for example, quoted Piers the Ploughman, a fourteenth-century polemic against the friars, as readily as he tackled descriptions of early modern legal cases.

Schechter's use of history as a normative tool should come as no surprise. His father, Solomon Schechter, was one of the most distinguished Jewish historians of the late nineteenth century. He taught at Cambridge University and later served as President of the Jewish Theological Seminary in New York. Born in Rumania, the elder Schechter studied in Vienna and later at the Hochschule für die Wissenschaft des Judentums, which at that time was the center for revising traditional conceptions of the past with scholarly historical methods. Solomon Schechter's greatest contribution was no doubt his recovery during an expedition to Egypt in the years 1896-7 of a medieval Jewish archive, the Cairo Genizah, whose 140,000 items he brought to Cambridge. This remarkable collection of documents allowed for the reconstruction of a medieval Jewish community. ${ }^{122}$

Solomon Schechter was an activist scholar. In the tradition of the Wissenschaft, the senior Schechter recovered the past in order to alter the present. Older versions of Jewish life, grounded in rabbinic texts or medieval communities, were drawn upon for the different optic they provided. However, the norm of practice was to follow current community standards, which themselves were to be rationalized. It is not a far leap to suggest that Frank Schechter, who edited posthumously a work of his father's, was influenced by this approach. ${ }^{123}$ In his history of trademark law, he engaged in mining the past for alternative doctrinal moves; but, ultimately, he sought to institute trademark rules that embraced the reality of how marks function within psychological and economic realms, and to establish a rational alternative to what Felix Cohen called "transcendental nonsense."

Equally important, Schechter was at Columbia during the highwater mark for

122. Stefan C. Reif, A Jewish archive From Old Cairo: The History of Cambridge UNIVERSITY'S GENIZAH COLLECTION 47-53 (2000); NORMAN BENTWICH, SOLOMON SCHECHTER: A BIOGRAPHY 133, 158 (1940). Solomon Schechter's own interest in legal history may have been stimulated by his friendship with the preeminent Roman legal historian W.D. Buckland, who was Regius Professor of Law, when Schechter was at Cambridge University, see CYRuS ADLER, SOLOMON SCHECHTER, A BIOGRAPHICAL SKETCH 12-13 (1917).

123. Frank Schechter's role in editing his father's posthumous book, Studies in Judaism (third series) is described in a letter to the Jewish Publication Society, see Letter from Frank Schechter to the Jewish Publication Society (Jan. 23, 1923) (on file with the Jewish Theological Seminary Archives). For information regarding his involvement in other scholarly projects regarding his father, see also Letter from Frank Schechter to Sir James G. Fraser (Nov. 25, 1921) (on file with the Jewish Theological Seminary Archives) (discussing his role in collecting his father's correspondences and organizing the writing of his biography) and Letter from Frank Schechter to Norman Bentwich (Sep. 10, 1923) (on file with the Jewish Theological Seminary Archives) (also discussing his father's biography). In addition, Frank Schechter wrote a work on medieval English Jewry in which he attempted to use legal documents to reconstruct the emotional state of a Jewish community, which had hitherto only been "mere shadows." The influences of Maitland and Vinogradoff are evident throughout the essay. Frank I. Schechter, The Rightlessness of Medieval English Jewry, 4 JEWISH QUARTERLY REVIEW 121, 122 (1913-1914). 
legal realism. Between 1926 and 1928, ten members of the faculty attempted to reorder the curriculum along functional lines. The committee suggested that instead of the traditional doctrinal curriculum the focus should be on the functioning of law with subject areas such as risk allocation or the operation of business units. With some of the country's leading realists then at Columbiaincluding Herman Oliphant, William O. Douglas, and Underhill Moorefunctionalism was all the rage. The Historical and Comparative Jurisprudence Committee broadened the idea of legal history to include legal philosophy; the medieval and early modern law so close to Schechter's interests; and the normative remaking of legal institutions within their sociological and economic milieu. ${ }^{124}$ The Jewish Theological Seminary under the influence of Solomon Schechter's "realist" and historicist approaches shared with Columbia Law School more than simply the common territory of Morningside Heights.

Frank Schechter called for a radical departure for American trademarks. Trademark law, he believed, was "hampered by obsolete conceptions" that a trademark simply indicates the origins of goods, and had fraud at its core. Trademark doctrine must move beyond the traditional tort of palming off, whereby consumers were protected from confusion as to the source of the goods. Instead, Schechter argued, trademarks should be considered property since so much is invested in terms of advertising good will. He called for preserving trademarks held and used over time against any attempt to erode their distinctiveness even absent any sort of confusion. A mark should be protected against the gradual "whittling away or dispersion of the identity and hold upon the public mind of mark."125

Although this doctrine, known as trademark dilution, did not become federal law until it was eventually codified as the Federal Trademark Dilution Act of 1995 and incorporated into the Lanham Act, it became influential fairly quickly and was adopted by a number of states. ${ }^{126}$ Schechter is best remembered as the father of dilution doctrine. ${ }^{127}$ Under a dilution cause of action, trademarks would be protected even when the marks inhabit wholly separate markets or are applied to

124. Laura Kalman, Legal Realism at Yale 1927-1960 67-72 (1986); JUlius Goebel, JR., FOUNDATION FOR RESEARCH IN LEGAL HISTORY, A HISTORY OF THE SCHOOL OF LAW OF COLUMBIA UNIVERSITY (1955).

125. Schechter, Rational Basis, supra note 71 , at 825 .

126. Federal Trademark Dilution Act of 1995,15 U.S.C. $\S 1125$ (2000), amended by Trademark Dilution Revision Act of 2006, Pub. L. 109-312, 120 Stat. 1730 (to be codified at 15 U.S.C. $\S 1051$ (2006)). State adoptions are described below. Robert Bone, Schechter's Ideas in Historical Context and Dilution's Rocky Road (manuscript in possession of the author) states that Edward S. Rogers, who drafted the bill that eventually became the Lanham Act, was a leading proponent of the goodwill-asproperty theory, and therefore did not include dilution in the federal trademark statute. Bone further suggests that Rudolf Callman, a leading treatise writer, promoted dilution after Schechter's death, which allowed for the passage of state anti-dilution statutes. RUDOLF CALLMAN, THE LAW OF UNFAIR COMPETITION AND TRADE-MARKS $\S \S 80.3,84.2$ (a) (2d ed. 1950).

127. See, e.g., Trademark Dilution Revision Act of 2005: Hearing Before the Subcomm. on Courts, the Internet, and Intellectual Property of the H. Comm. on the Judiciary, 109th Cong. 27 (2005) (testimony of William G. Barber, American Intellectual Property Law Association) ("the genesis of the dilution doctrine in this country is commonly traced back to an article by Professor Frank I. Schechter"). 
wholly different classes of goods. If the mark lessened in value simply through being used over time by a non-competitor such that the original mark became less distinct in the minds of consumers or, alternatively, it was tarnished through disparagement of the mark, then the original mark would lose its psychological power. With dilution, Schechter's focus on psychology came full circle. Schechter's dilution doctrine indeed meant that the concern was not simply consumer deception— but the complex array of mental images conjured by a mark.

Schechter imported the concept of dilution from German law. No doubt he was influenced by his own exposure to German scholarship under the tutelage of his father and through his experiences as a military officer during the occupation of Germany in World War I. The most important precedent was the landmark German Odol case. ${ }^{128}$ A registered mark, Odol was widely known as a tooth cleansing preparation and mouthwash. Nevertheless, a steel manufacturer registered this trademark for its own products. The mouthwash manufacturer filed for cancellation of the steel manufacturer's mark. Finding in favor of the plaintiff's cancellation claim, the court held that the mark would lose in selling power if anyone, even non-competitors, used it for the designation of goods. ${ }^{129}$

In 1932, Congress considered legislation, drafted in part by Schechter, which would have enacted dilution doctrine under federal trademark law. ${ }^{130}$ However, dilution protection was not adopted at that time or even later when the final version of the Lanham Act was passed. As one contemporary commentator noted, courts were moved to expand findings of infringement where there was likelihood of confusion in cases which would have been better analyzed through dilution doctrine. ${ }^{131}$ Dilution doctrine was pertinent in at least one well-known case, Tiffany \& Co. v. Tiffany Productions, in which the defendant, a motion picture producer was enjoined from using the name, "Tiffany," in any manner connected with his business. ${ }^{132}$

Dilution doctrine did take root at the state level. Massachusetts passed the first trademark dilution statute in 1947..$^{133}$ Illinois, Georgia, and New York quickly followed suit. ${ }^{134}$ Eventually, with the passage of the Federal Trademark Dilution Act in 1995, codified as section 43(c) of the Lanham Act, Congress belatedly

128. Thomas R. Lee, Demystifying Dilution, 34 B.U. L. REV. 859, 868 (2004); Walter J. Derenberg, The Problem of Trademark Dilution and the Antidilution Statues, 44 CAL. L. REV. 439, 44849 (1956).

129. Schechter, Rational Basis, supra note 71, at $831-32$ (quoting a 1924 German court decision, Landesgerich at Elberfeld).

130. H.R. 11592, 72nd Cong. (1932).

131. Rudolf Callman, Unfair Competition without Competition? The Importance of the Property Concept in the Law of Trade-Marks, 95 U. PA. L. REV. 443, 448-449 (1947).

132. 264 N.Y.S. 459 (N.Y. Sup. Ct. 1932), aff'd, 260 N.Y.S. 821 (App. Div. 1932). See also John Forsythe Co., Inc. v. Forsythe Shoe Corp., 254 N.Y.S. 584, 586, 587-588 (App. Div. 1932) (men's haberdashery sues to enjoin use by women's clothing store where the court stated that there was a possibility of confusion, but disregarded showing of actual confusion).

133. Act of May 2, 1947, ch. 307, 1947 Mass. Acts 300.

134. Act of June 24, 1953, S.B. No. 292, 1953 Ill. Laws 455; Act of March 4, 1955, No. 240, 1955 Ga. Laws 453; Act of April 18, 1955, ch. 453 § 1, 1955 N.Y. Laws 1127. 
promulgated federal protection against dilution. ${ }^{135}$ Dilution doctrine represented a shift from a tort model to a proprietary model of trademark. ${ }^{136}$ Trademarks had been transformed into a distinct form of property with uncanny psychological power.

\section{From Symbol to ACT}

As early as 1920, the American Bar Association Patent, Trademark, and Copyright Section sought to draft a revision of the then-existing trademark laws, including the frequently amended 1905 Trademark Act. ${ }^{137}$ Schechter urged the passage of a bill which would have made federal trademark registration not merely procedural but substantive as well. ${ }^{138}$ This was also an opportunity to expand trademark beyond the territorial limitations of local markets. As proposed in a draft of a bill circulating in the House Committee on Patents, and formulated by Schechter, registration would have been refused where it was likely to cause harm to the good will of another mark even in a remote or non-competing market. ${ }^{139}$

In 1938, Texas Congressman Fritz G. Lanham introduced the federal trademark act which bears his name. While Congressional preoccupation with World War II delayed its passage until 1946, the bill was debated throughout this period. To a certain extent, the Lanham Act was a federal codification of pre-Lanham Act trademark law. In this regard, the Lanham Act was intended to order a tangled web of common law, state statutes, and limited federal regulation, and to promote national uniformity in trademark law. ${ }^{140}$ The goals of the legislation included preventing diversion of trade through commercial misrepresentation, protection of

135. 15 U.S.C.A. $\$ 1125$ (c) (2000).

136. See 15 U.S.C. $\S 1065$ (2000); 15 U.S.C. $\S 1115(b)$ (2000). See also 15 U.S.C. $\S 1125(\mathrm{c})$ (2000).

137. Trade-Mark Act of 1905, ch. 592, 33 Stat. 724. The Act was amended sixteen times between 1905 and 1938. Act of May 4, 1906, ch. 2081, §§ 1-3, 34 Stat. 168, 169; Act of March 2, 1907, ch. 2573, $\S \S 1,2$, 34 Stat. 1251, 1252; Act of February 18, 1909, ch. 144, 35 Stat. 627, 628; Act of February 18, 1911, ch. 113, 36 Stat. 918; Act of March 3, 1911, ch. 231, \& 291, 36 Stat. 1167; Act of August 24, 1912, ch. 370, § 5, 37 Stat 498; Act of January 8, 1913, ch. 7, 37 Stat. 649; Act of March 19, 1920, ch. 104, $\S \S 1-9,41$ Stat. 533; Act of June 7, 1924, ch. 341, 43 Stat. 647; Act of March 4, 1925, ch. 535, $\S \S$ 1, 3, 43 Stat. 1268; Act of March 2, 1929, ch. 488, § 2(b), 45 Stat. 1476; Act of April 11, 1930, ch. 132, $\S 4,46$ Stat. 155; Act of June 7, 1934, ch. 426, 48 Stat. 926; Act of June 20, 1936, ch. 617, 49 Stat. 1539; Act of June 25, 1936, ch. 804, 49 Stat. 1921; Act of June 10, 1938, ch. 332, $\S \S 1-3,5,52$ Stat. 638, 639. See Beverly W. Pattishall, The Lanham Trademark Act-Its Impact over Four Decades, 76 TRADEMARK REP. 194, 195 n. 16(1986).

138. The Trade-Mark Act of 1905, ch. 592, 33 Stat. 724 was the first national trademark statute passed after the Supreme Court's decision in the Trade-Mark Cases. The Act provided a procedural mechanism for national registration, but created no new substantive rights. Indeed, Section 23 of the Act expressly stated that common law rights were unchanged by the Act.

139. Schechter, Fog and Fiction, supra note 82, at 84-5.

140. A renewed interest in trademark registration was taking place at the state level in the 1930s, and numerous states considered legislation that would have established registration as the "sole determinant of ownership." The cost of multiple state registrations, and the significant possibility that registration might be seen as a means of raising revenue, was a source of concern to businessmen and members of the bar. Sylvester J. Liddy, Has Congress the Constitutional Power to Legislate on the Substantive Law of Trade-Marks?, 6 FORDHAM L. REV. 408, 409 (1937). 
the public against exposure to similar trademarks, and establishment of a registration system to provide fair notice of existing marks. When reporting the Lanham draft legislation, the Senate Committee on Patents stated that "the purpose of this bill is to place all matters relating to trademarks in one statute and to eliminate judicial obscurity ... to make procedure simple, and relief against infringement prompt and effective." 141

Section 43(a), which established the standard for trademark infringement, was originally restricted to palming off, defined as the conduct of selling goods as to mislead the public as to the actual source of the goods. ${ }^{142}$ However, a far-reaching revision of existing trademark law extended it further. The new standard of likelihood of confusion went beyond the idea of a market with directly competing goods, establishing a remedy where there existed a use "likely to cause confusion or mistake or to describe the purchasers as to the source of origin of such goods or services." 143

The Justice Department censured the Act for its potential role in protecting monopoly. Shortly before passage, the Lanham Act was amended to provide the Federal Trade Commission the power to bring cancellation actions, ${ }^{144}$ nullifying incontestability for those marks used in violation of antitrust law, ${ }^{145}$ and otherwise limiting incontestability. ${ }^{146}$ These were new innovations that embraced a role for the FTC regulation and brought the threat of antitrust action to the doorstep of trademark regulation. ${ }^{147}$ Clearly, some lingering concerns over monopoly power remained. ${ }^{148}$

The bill was a marvelous example of New Deal thinking. Like so many New Deal initiatives, it extended the reach of federal regulation on the grounds of an expansive reading of the Commerce clause. While even Casper Ooms, the United States Commissioner of Patents and a supporter of the Lanham Act, had to admit that it stretched the Commerce clause to regulate trademarks for local businesses as well as those engaged in interstate commerce, he argued that increasingly the

141. S. REP. No. 79-1333, at 3 (1946).

142. Ethan Horwitz \& Benjamin Levi, The Lanham Act Turns Fifty: Fifty Years of the Lanham Act: A Retrospective of Section 43(a), 7 FORDHAM INTELL. PROP. MEDIA \& ENT. L.J. 59, 61-62 (1996).

143. 15 U.S.C. $\$ 1114(2000)$.

144. Lanham Act, $\S 14,15$ U.S.C. $\S 1064$ (2000).

145. Lanham Act § 33(b)(7), 15 U.S.C. § 1115(b)(7) (2000).

146. Lanham Act $\S 15$, 15 U.S.C. $\$ 1065$ (2000).

147. Herbert Koshetz, Revisions Sought in Trade-Mark Act, N.Y. TIMES, Dec. 12, 1948, at F6; Alfred R. Zipser, Jr., Sees Lanham Act Dooming Piracy, N.Y. TIMES, Oct. 1, 1947, at 31; Trade-Mark Posed as World Problem, N.Y. TIMES, Apr. 24, 1948, at 22.

148. Even in the wake of the Lanham Act, however, courts remained inhospitable to the extension of what were perceived as monopoly trademark rights. In California Fruit Growers Exchange v. Sunkist Baking Co., 166 F.2d 971 (7th Cir. 1947), which was decided almost immediately after the passing of the Lanham Act, the Seventh Circuit overruled the trial court decision in favor of fruit growers who claimed that the use by bakers of their registered trademark, "Sunkist," constituted infringement. The Appellate court called the trademark action "the unconscionable efforts of the plaintiffs to monopolize the food market by the monopoly of the word 'Sunkist' on all manner of goods sold in the usual food stores." Id. at 974. See Rudolf Callmann, The "Sunkist" Decision: Trade-Marks at the Crossroads, 38 TRADEMARK REP. 304 (1948) (criticizing the court for asserting that use of a trademark alone allows for the exercise of monopoly power over a market). 
Commerce clause was used elastically to bring all sorts of commercial regulation under the ambit of Congressional regulations. ${ }^{149}$ Trademark law was simply another example of the regulation of unfair competition. It was an important next step after Erie because it helped create a firmer federal framework for business law, and established a substantive federal trademark law distinct from the common law of the states. ${ }^{150}$

As the first substantive federal trademark statute, the Lanham Act both reflected and constituted a national market. Individual desire had created a consumer republic that was recognized for its unbounded territories. Acquisition of goods was a soliloquy - a relationship of a single prudent consumer (to use trademark terms) with an object. It was also a form of address of individuals with one another as they signaled social status and affiliations. Consumer goods constituted a dynamic, often turbulent commercial world of symbols. ${ }^{151}$

Rather than have expensive lawsuits emerge between marks in an increasingly dynamic economy, Ooms claimed, trademark registration would determine the manner or place of the trademark use. ${ }^{152}$ The Lanham Act would create the informational infrastructure for the pax keynesiana, assuring product differentiation. An incontestability provision and federal registration quieted title, reassuring manufacturers that they could freely invest in advertising and in the maintenance of their good will. It was policed by other actors in the marketplacethose who held other trademarks - and might challenge the registration of a mark. In the New Deal's regulatory model, an administrative agency would ensure that there would be scrutiny of marks. Such a bill also had the hallmarks of Lanham's own thinking. He supported the idea of spurring the economy through strengthening markets. On one hand, he opposed the restrictive inter-war tariff policies of the Republicans, on the other hand, he objected to Roosevelt's reliance on a cumbersome administrative apparatus as a tool of economic development. Lanham preferred the extension of credit rather than direct subsidies. ${ }^{153}$ In much the same way, the Lanham Act was a limited federal intervention in the marketplace.

Especially worrisome to business were two sections added late in the process to the Lanham Act in a joint Senate-House conference. ${ }^{154}$ Section 14, which provided the FTC with jurisdiction to apply for cancellation at any if the mark becomes a common descriptive name of an article on which the patent has expired and for

149. Casper W. Ooms, How the Lanham Act Affects Trade-Marks, 37 TRADEMARK REP. 383, 386 (1947).

150. S.C. Johnson \& Son, Inc. v. Johnson, 175 F.2d 176, 178 (2d Cir. 1949).

151. For the soliloquy approach, see generally COLIN CAMPBELL, THE ROMANTIC ETHIC AND THE SPIRIT OF MODERN CONSUMERISM (1987); DOUGLAS \& ISHERWOOD, supra note 107. See also JeanChristopher Agnew, Coming up for Air: Consumer Culture in Historical Perspective, in CONSUMPTION AND THE WORLD OF Goods 19, 25 (John Brewer \& Roy Porter eds. 1993).

152. Alfred R. Zipser, New Ana Chairman Sees Lanham Act Dooming Piracy, N.Y. TIMES, Oct. 1, 1946 , at 31 .

153. Nancy Beck Young, Entry on Fritz Lanham, in 13 AMERICAN NATIONAL BIOGRAPHY 168, 168 (John A. Garraty \& Mark C. Carnes eds., 1999).

154. Herbert Koshetz, Revisions Sought in Trade-Mark Act, N.Y. TIMES, Dec. 12, 1948, at F6. 
certain other reasons. This permitted the FTC to be involved in those cases, like the famous case of Kellogg Co. v. National Biscuit Co., where the United States Supreme Court decided that Shredded Wheat had lost its protection as a trademark because it described the nature of the cereal after a patent had expired, rather than the identity of its producer. ${ }^{155}$ Businesses were troubled by this provision because courts might strip away protection from a mark, and all the goodwill accrued over time would be suddenly dissipated. Section $33(B)(7)$ makes violation of the antitrust laws an affirmative defense in a suit of trademark infringement and a defect to the incontestable exclusive right in the mark.

But was Schechter right? Did the mind create a space where anti-competition issues were less relevant? In a classic law review article which marked an early use of law and economics in the field of intellectual property, Ralph Brown, who during his long tenure at Yale Law School taught one of the first classes on copyright in the country, pointed out that advertising works in a variety of economic ways to benefit the consumer. ${ }^{156}$ Advertising lowers information costs. As more consumers purchase the product, the unit cost declines. There are intangible benefits from advertising as well-consumers are assured of reliability, and it can provide the illusion of luxury, security, or romance. Yet most advertising is not meant to inform, but to persuade.

Persuasive advertisement consumes resources that might otherwise be used to produce more goods and services. All this persuasion, Brown reminded the reader, is meant to differentiate a product so that it stands alone, apart from competitors. Brown suggested that courts should differentiate between the socially useful informational function of advertising from the socially less useful persuasive aspect. However, Brown also recognized that these two are inextricably intertwined. His article echoed Veblen: If we leave the market, and speak of the mind-ultimately persuasion in the mind is meant to direct, if not manipulate, purchases in the market. A trademark, in the words of Justice Frankfurter, is a species of "commercial magnetism." 157

\section{COPYRIGHT AND THE POLITICS OF INTELLECTUAL PROPERTY'S INDUSTRIAL PLURALISM}

Like trademark, copyright was identified with monopoly. In his classic 1945 article, Reflections on the Law of Copyright, Zechariah Chafee, Jr. underscored the fact that copyright was a monopoly, and urged a weighing of the burdens whenever it was evoked. ${ }^{158}$ The well-known Hand Abstraction Test for copyright infringement, too, is an example of the limitations which might be set on a

155. 305 U.S. 111 (1938).

156. Ralph Brown, Advertising and the Public Interest: Legal Protection of Trade Symbols, 57 YALE L.J. 1165 (1948), reprinted in 108 YALE L.J. 1619 (1999).

157. Mishawaka Rubber \& Woolen Mfg. Co. v. S.S. Kresge Co., 316 U.S. 203, 205 (1942).

158. Zechariah Chafee, Jr., Reflections on the Law of Copyright: I, 45 CoLUM. L. REV. 503, 506 (1945). 
monopoly. ${ }^{159}$ Exclusive ownership is limited to the expression. "Themes, ideas, and plots in books or plays are a common fund from which every author may draw the basic materials of his work without restriction. They are not subject to exclusive ownership." 160

However, copyright also raised issues of collective action. Powerful media forces-such as phonograph, radio, and film studios-dominated copyright in a way that no single handful of manufacturers could have controlled the commercial world of trademark. ${ }^{161}$ Groups of authors or industrial designers took to collective action. This shift to cartels suggested that New Deal intellectual property law would have to balance opposing political interests.

This section describes how intellectual property became an arena of policy debates between competing interest groups, a phenomenon which continues to the present day. ${ }^{162}$ Two narratives concerning the emergence of intellectual property industrial pluralism in the New Deal will be examined. The first narrative details the increasing dominance of the recorded music industry by a limited number of economic actors, and the strengthening of infringement policing power through the creation of a royalty collection society. This prompted a response by competing constituencies. Fearing what they considered monopolistic combination, groups of copyright users banded together to demand legal limits be imposed on these societies. The struggle between these competing interest groups took place in courts, state legislatures, and in the public sphere. Ultimately, Congress was called upon to step into the breach and negotiate a settlement. Recognizing copyright's economic importance, and especially the significance of new media technologies such as radio, Congress assumed the role of umpire in intellectual property policy debates.

The second narrative describes the problem of industrial design. With the emergence of mass production, certain designs for clothing and other industrial goods became subject to rapid and inexpensive copying by competitors. Companies had little time to exploit the economic value of original designs, which fell outside the ambit of design patent protection. Businesses sought relief from free-riding competitors in a number of ways, such as calling for new legislation and judicial interventions. Especially intriguing was the creation of self-help mechanisms through trade associations and through New Deal sponsored National Recovery Act Codes. The New Deal focus on industrial design reflected notions of balancing the competing needs of producers and consumers, those who create original designs and of those companies who come later and utilize those designs to

159. See Nichols v. Universal Pictures Corp., 45 F.2d 119 (2d Cir. 1930).

160. Golding v. R.K.O. Pictures, 221 P.2d 95, 102 (Cal. 1950) (Traynor, J., dissenting).

161. See, e.g., Interstate Circuit, Inc. v. United States, 306 U.S. 208, 226-27 (1939) (copyright is a monopoly providing exclusive rights for the holder, but which cannot be combined through contracts with others to create a restraint of trade).

162. Jessica LitMAn, Digital COPYRIGHT 35-63 (2001); Jessica Litman, Copyright, Compromise, and Legislative History, 72 CORNELL L. REV. 857 (1987) (detailing how special interest groups shaped copyright law); Dan L. Burk \& Mark A. Lemley, Policy Levers in Patent Law, 89 VA. L. REV. 1575 (2003) (describing the overwhelming effect of competing interest groups in shaping the Patent Act). 
create mass consumer goods for ordinary citizens. If New Deal trademark policies announced the birth of the consumer republic, the era's copyright policies reflected a polity where interest politics reigned.

\section{A. Copyright in an Age of Mechanical Reproduction}

Much had changed between the passage of the 1909 Copyright Act's protection of traditional literary property and the beginning of the New Deal. New technologies-such as radio and motion pictures-played an increasingly important role. American cultural and artistic productions were exported abroad. A particularly notable change was the emergence of a major copyright royalty collection society and its opponents. The presence of a new interest group based politics of copyright stalled attempts at statutory revision.

One of the most perplexing issues in early twentieth-century intellectual property law was the protection of sound recordings. Written musical notation had received statutory protection in the United States since $1831 .{ }^{163}$ In the beginning of the twentieth century, however, Americans had their first brush with what might be the monopoly power of a corporation that controlled vast numbers of music licenses. Aeolian Company, the world's leading piano roll producer, sought to establish a monopoly on a significant portion of well-known music through patent. When this failed, the company then sought to secure exclusive recording rights. ${ }^{164}$ The 1909 Copyright Act was passed in the wake of this controversial attempt to corner the music market.

The Act introduced a statutory license provision. Whenever the owner of a musical copyright permitted the use of copyrighted work on instruments "serving to reproduce mechanically the musical work," a compulsory license would issue upon the payment of a two cents royalty. ${ }^{165}$ This provision was intended to prevent monopolies, and therefore acted for much the same purposes as anti-trust. It reflected the fear that one powerful record company, such as RCA-Victor, might acquire the monopoly over most recorded music. ${ }^{166}$

Observers often attributed the unusual ferocity of the debates over sound recordings to the organization of conflicting interests. ${ }^{167}$ "The history of American copyright law has been one of surging conflict between opposing economic groups," began the author of a 1938 law review note. ${ }^{168}$ Creators, motion picture distributors, tavern owners and radio broadcasters all expressed competing interests. Indeed, the struggle over the issue would hold up legislative attempts at copyright revision for years. From 1926-1931, despite numerous calls for reforming the increasingly out-of-step 1909 Copyright Act, only a single copyright

163. Act of Feb. 3, 1831, ch. 16, 4 Stat. 436.

164. See White-Smith Music Publishing Co. v. Apollo Co., 209 U.S. 1 (1908).

165. 35 Stat. 1076 (1909), 17 U.S.C. \& 1(e) (1926).

166. Milton Diamond \& Jerome Adler, Proposed Copyright Revision and Phonograph Records, 11 AIR L. REV. 29, 39 (1940).

167. Chafee, Jr., supra note 158 , at 516-17.

168. Note, Copyright Law and Its Sanctions, 7 BrooK. L. REV. 523 (1938). 
act was passed-one that increased fees. ${ }^{169}$. The Committee on Patents of the House of Representatives considered bills each year, but these failed on the floor.

Much of the blame was leveled at American Society of Composers, Authors, and Publishers (ASCAP), an organization founded by a group of composers, lyricists, and music publishers in 1914 for the purpose of preventing literary piracy. Composers would assign rights to ASCAP, which would issue blanket licenses at fixed fees for all their protected work. To be a member of ASCAP, a member must have had five successful popular songs and assign such rights for a period of five years. ${ }^{170}$ Different blanket fees would be charged different industries. Moving picture theaters, for example, were charged at a per seat rate. ${ }^{171}$ ASCAP investigators vigilantly pursued possible copyright violations in restaurants, hotels, theaters, and bars. ${ }^{172}$ These investigators were paid on a commission basis and therefore tended to pursue a large number of violators. ${ }^{173}$

Federal courts declared radio transmissions public performances for profit. ${ }^{174}$ As such, composers and publishers were legally permitted to charge fees, though they found it difficult to enforce their copyrights. From 1938 to 1948 , the number of stations on the air tripled, and it appeared that either radio station owners or the producers of music would be the beneficiaries of this remarkable growth. ${ }^{175}$ Perhaps nothing could be easier for a radio station anxious to fill air time than to play phonograph records. Profits rose steeply as advertisers, active participants in the consumer republic, competed for the attention of listeners. By 1934, approximately one-third of network time was sold as sponsored programming. ${ }^{176}$

As early as 1922, ASCAP began to demand radio stations pay annual fees in return for the right to use recorded music whose copyright was held by members. ${ }^{177}$ At first, ASCAP charged nominal fees to the fledgling broadcasting industry; but as radio became a commercial success, ASCAP increasingly sought a share of profits, and often demanded, and received, a fixed fee plus percentage of the radio station's commercial income. ${ }^{178}$ Some recordings, such as those of Bing Crosby and Fred

169. 45 Stat. 713 (1928), 17 U.S.C. $\$ \S 57,61$ (Supp. 1929).

170. Eileen C. O'Connor, Anti-ASCAP Legislation and Its Judicial Interpretation, 9 GEO. WASH. L. REV. 713, 714 (1940-41). On ASCAP in general, see PAUL GOLDSTEIN, COPYRIGHT'S HIGHWAY: FROM GUTENBERG TO THE CELESTIAL JUKEBOX 69-76 (1994).

171. ALFRED M. SHAFTER, MUSICAL COPYRIGHT 314-15 (1939).

172. Id. at 316 .

173. See Revision of Copyright Laws: Hearings Before the H. Comm. on Patents, 74th Cong., 2d Sess. 44 (1936).

174. See, e.g., Herbert v. Shanley Co., 242 U.S. 591, 594-95 (1917) (holding that public performances, even where no admissions fees are charged, constitute for-profit performance, and so can amount to copyright infringement); Jerome H. Remick \& Co. v. Am. Auto. Accessories, 5 F.2d 411 (6th Cir. 1925) (determining that radio broadcast of music constitutes public performance under the 1909 Copyright Act); M. Whitmark \& Sons v. L. Bamberger \& Co., 291 F. 776, 779-80 (D.N.J. 1923) (finding sponsor of radio broadcast infringed musical copyright).

175. William C. Ackerman, U.S. Radio: Record of a Decade, 12 PuB. OPINION Q. 440, 441 (1948).

176. ERIK BaRNOUW, THE GOLDEN WEB: A HISTORY OF BROADCASTING IN THE UNITED STATES 1933-1953 16-17 (1968).

177. William Barlow, Black Music on Radio During the Jazz Age, 29 AFr. AM. Rev.325, 325 (1995).

178. Note, ASCAP and the Antitrust Laws: The Story of a Reasonable Compromise, 2 DUKE 
Waring, placed warnings on their labels that the music was not licensed for radio broadcast. ${ }^{179}$ Critics argued that ASCAP fees exceeded those commonly retrieved under fair licensing. ASCAP countered that it was nothing more than a policing mechanism through collective action against copyright infringement.

ASCAP's market power relied upon its success in signing composers and publishers. By $1939,70 \%$ to $90 \%$ of contemporary successful popular music titles were covered by its agreements. ${ }^{180}$ Hotel and tavern owners became major targets, and therefore opponents, of ASCAP. Since it was difficult to know if a song was licensed or not, hotels purchased a blanket license from ASCAP. Justice Oliver Wendell Holmes' 1917 decision in Herbert v. Shanley, which provided for copyright infringement lawsuits in cases of both indirect and direct commercial use, opened up the door to a broad array of infringement litigation. ${ }^{181}$ Few legal defenses were available for defendants in infringement suits as courts over the ensuing two decades struck down one possible defense after another. ${ }^{182}$

With the courts strongly supporting the rights of copyright owners, Congress had little choice but to address the contentious issue of music collection societies. A major attempt to revise the 1909 Copyright Act, the Vestal Bill, was introduced May 22, 1930. It passed the House in 1931, but failed to pass the Senate the same year due to a filibuster. ${ }^{183}$ The Vestal Bill's purpose was to provide for (1) automatic copyright, whereby protection is conferred upon the author upon creation of his work; (2) divisible copyright, which permits the assignee, grantee, or licensee to protect and enforce any right which he acquires from an author; and (3) international copyright, which enables American authors, merely by complying with the provisions of this act, to secure copyright throughout various countries without further formalities. ${ }^{184}$ The bill would have altered the copyright term from 28 years, renewable to life plus 50 years after the death of the author. It also would have abolished the compulsory licensing provisions for music ( $2 \%$ royalty) with regard to mechanical reproductions of music.

Clearly, the Vestal Bill was meant to rework the copyright statute to permit the United States to join the International Union for the Protection of Literary and Artistic Works - generally known as the Berne Convention-for the first time since its formation in 1886. Other countries had automatic copyright provisions, and the United States needed to jettison its reliance upon registration and formalities in order to be compliant. With America's rapidly growing number of cultural exports,

L.J..258, 258-63 (1959).

179. BARNOUW, supra note 176 at 217.

180. SHAFTER, supra note 171, at 311-12.

181. 242 U.S. 591 (1917) (performance of copyrighted musical composition in restaurant without admission charge infringes on exclusive right of copyright owner to fees for public performance for profit).

182. Dreamland Ballroom v. Shapiro, Bernstein \& Co., 36 F.2d 354 (C.C.A. 1929) (lack of authority over orchestra); M. Witmark \& Sons v. Calloway, 22 F.2d 412 (Tenn. 1927) (lack of intent to infringe); Hubbell v. Royal Pastime Amusement Co., 242 Fed. 1002 (S.D.N.Y. 1917) (alleged lack of composer's intent to write music for purpose of public performance for profit).

183. H.R. 549, 71 st Cong. (1931).

184. Id. 
such as music and film, it was considered critical for American companies to have stronger copyright protection abroad. ${ }^{185}$ Much as the Lanham Act created a national intellectual property market for trademarks, copyright revision was meant to establish an international market for American cultural products. Moreover, the provision for a divisible copyright followed the move towards creating additional proprietary rights.

The issue of sound recordings remained troublesome, as the Vestal Bill provided for a broad definition of infringement in various media. This was especially notable in light of the automatic copyright provided in the bill absent preliminary formalities, which would have shifted the burden to the broadcaster to avoid infringement. The bill also provided mitigation for innocent infringement. ${ }^{186}$ In the course of heated debate, several amendments were added, such as one providing that the bill should not apply in places of entertainment playing radio music unless a specific admission fee was charged. ${ }^{187}$ Another amendment provided that reproduction of a musical composition on a coin-operated machine, such as a nickelodeon, would not be deemed a public performance for profit. ${ }^{188}$

These amendments reflected the interests of small shopkeepers, barbers, tavern keepers, and various retailers who marshaled forces against the Vestal Bill. The compulsory licensing provisions were declared an insufficient bulwark against the monopoly power of ASCAP. It was thought unfair that there was no combination of consumers to balance the combination of producers, and the compulsory license was seen as the sole protection against the music cartel. One of the major Congressional opponents of the Vestal Bill, Representative Busby of Mississippi, proposed various amendments with a strong anti-monopoly flavor, including rendering unlawful the combining of copyright owners to fix royalty rates for mechanical reproduction of music. ${ }^{189}$

ASCAP, on the other hand, claimed that they were forced to license music at a rate far below market prices. Indeed, ASCAP portrayed an endangered industry; it claimed that playing music on the radio posed a real risk by showing a precipitous drop in sheet music, phonograph record and player piano roll sales. The sale of phonograph records, for example, dropped from industry receipts of more than $\$ 47,000,000$ in 1921 to less than $\$ 4,000,000$ in $1935 .{ }^{190}$ The news for ASCAP was even worse at the state level. In Texas, a confiscatory bill was proposed, which

185. Catherine Seville, The Internationalisation of COPYright LaW: Books BuCCANeERS AND THE BLACK FlaG IN THE NineteENTH CENTURY 146-152 (2006) (describing America's aloof nineteenth-century response to the Berne Convention).

186. Sec. 15(d).

187. 72 CONG. REC. 157 12428, et. seq. (1930).

188. Id.

189. Id. The Vestal Bill was opposed by the National Association of Broadcasters, the Radio Manufacturers' Association, and the Radio Protective Association, see Radio Men See a Peril in the Copyright Bill, N.Y. TrMES, Feb. 8, 1931, at 121.

190. Walter L. Pforzheimer, Copyright Protection for the Performing Artist in his Interpretive Rendition, 1 COPYRIGHT L. SYMP. 14 (1939). This is based upon figures from the United States BiAnnual Census of Manufacturers, 1936, Department of Commerce. 
would have established a $25 \%$ tax on all ASCAP fees collected. ${ }^{191}$ Clearly, 1930 was an annus mirablis for ASCAP. In response, it published two pamphlets in the wake of the Vestal Bill battle, a 1932-33 pamphlet, the "Murder of Music," and "How the Public Gets its New Music." ASCAP insisted that it was not a cartel. Indeed, their pamphlet, The Story of ASCAP: An American Institution, begins with a section entitled "What ASCAP is Not." It was not-so it claimed-a trade union, a corporation, or a trade association. ${ }^{192}$

ASCAP portrayed its role as simply providing a mechanism for enforcing existing copyright law. Countering the idea of the organization as a trust, ASCAP stated that its purpose was to ensure that "no man or woman in the United States who writes successful music, or anyone dependent upon him, shall ever want.", 193 However, it did not simply portray itself a beneficial organization for independent composers. ASCAP also asserted that it played a critical role in the struggle between tyranny and freedom. On one side, there was "mechanized culture," where a man was not free to "express himself as 'I'; the last chance of freedom;" on the other side - in the United States - there was a "vital organistic living culture" which had to be protected. Copyright was said to safeguard freedom, ensuring the survival of the lone artist or composer, who like ASCAP, formed the lifeblood of the creative enterprise. ${ }^{194}$

As ASCAP claimed that it was an agent for collecting just compensation that rightfully belonged to hard-working Tin Pan Alley composers and lyricists, its opponents drew unstintingly upon monopoly rhetoric. In Congressional hearings over copyright revision, ASCAP called was called a band of "racketeers." 195 When the Vestal Bill was introduced, one member of Congress offered an amendmentwhich was rejected - that "a combination to fix royalty rates for use of any copyrighted work ... shall be unlawful." 196

The Justice Department also entered the fray. In a case brought on August 30, 1934 at the behest of hotel and tavern owners and other licensees, the Federal Government sued ASCAP under the Sherman Act as a combination in restraint of trade. ${ }^{197}$ ASCAP, it was claimed, was a self-perpetuating body which controlled the

191. Paul Gitlin, Radio Infringement of Music Copyright, 1 COPYRIGHT L. SYMP. 61,80 (1938).

192. THE STORY OF ASCAP: AN AMERICAN INSTITUTION 4.

193. Id. at 8 .

194. Id. at 11-15.

195. Revision of Copyright Laws: Hearings before the Committee on Patents concerning Copyright Revision H.R. 74th Cong. 2, 54-56 (2d Sess. 1936); 79 CONG. REC. 12253 (1935) (Sen. Wagner reads into the record the names of authors and artists members of ASCAP to dispel claim that they are "racketeers"); 79 CONG. REC. 12562 (1935) (Sen. Duffy states it is not members who are racketeers, but an organization which is currently being prosecuted under anti-trust law). Some of this anti-ASCAP language may have had anti-Semitic overtones since some $60 \%$ of Tin Pan Alley composers were Jewish, and these wrote about $70 \%$ of the successful songs. Edward Pessen, The Great Songwriters of Tin Pan Alley's Golden Age: A Social, Occupational, and Aesthetic Inquiry, 3 AMER. MUSIC. (1985) 180, 184.

196. Gitlin, supra note 191, at 68 .

197. Music Composers Sued as Monopoly, N.Y. TIMES, Aug. 31, 1934, at 15. VARIETY, Nov. 6, 1934 has extensive discussion of ASCAP brief. 
copyright of $75 \%$ of the country's popular music. ${ }^{198}$ It was identified as an example of copyright pooling; much like the patent pooling which, as we will see, was vigorously prosecuted. The suit was ultimately dropped. ${ }^{199}$ This antitrust action, nevertheless, seemed to have shaken ASCAP. But the news from Congress was even worse. In 1935, the Duffy Bill was proposed with the support of ASCAP's opponents; broadcasters, movie exhibitors, hotel owners, and other licensee groups. ${ }^{200}$

The Duffy Bill provided for the elimination of the entire statutory damage clause by substituting a provision for actual or proven damages and profits. It read in pertinent part: "such damages, not exceeding $\$ 20,000$ for all infringements ... as shall in the opinion of the court be sufficient to prevent their operation as a license to infringe ...." The bill would have removed the $\$ 250$ minimum damage clause and also the right to get an injunction against the radio broadcast of copyrighted works. ${ }^{201}$ Most importantly, the proposed statute provided that reception by radio did not constitute copyright infringement "except where admission of fees other than for ordinary occupation by a guest of a hotel ... are charged to the place of operation or in case of restaurants, cover charges distinct from charges for food and other minimum charges are made." ${ }^{202}$ Clearly, this bill was a strong nod towards the licensees.

ASCAP argued that removing the $\$ 250$ minimum would eliminate a needed incentive for songwriters and create uncertainty as to the damages, since proof of actual damages is difficult. Those lobbying for its removal claimed that a statutory minimum would be used as a club against them in contract negotiations. ASCAP feared that the use of actual damages might mean that the copyright act would simply function as a free compulsory license for any group whose payment would be too low to be worth litigation. ${ }^{203}$ ASCAP abandoned its pose of invulnerability, instead insisting that Congress should take into account the difficulty of ASCAP policing and understand the need for tough statutory damages as a punitive measure. $^{204}$

The rhetoric surrounding the sound recording debate was ferocious, but within the 1935 Congressional debates over the Duffy Bill, Senators spoke of the need to

198. Id. at 15 .

199. Revision of Copyright Laws: Hearing Before the Committee on Patents, 74th Cong. 13, 15, 16 (2d Sess. 1936); Note, supra note 158, at 524-25 (1937-38). A 1941 consent decree between ASCAP and the federal government established a rate scale to insure against any discrimination or favoritism. See THE STORY OF ASCAP 6. Other antitrust suits would be filed against ASCAP with some success, see Note, ASCAP Monopoly Violates Sherman Act: Copyrights, Monopolies, ASCAP's Blanket Licensing of Performance Rights Enjoined in Suit by Movie Exhibitors, 1 STAN. L. REV. 538-46 (1949); Sigmund Timberg, The Antitrust Aspects of Merchandising Modern Music: The ASCAP Consent Judgment of 1950, 19 LAW \& CONTEMP. PROBS. 294-322 (1954).

200. S.7 H.R. 2695, H.R. 3004, 75th Cong. (1937). The Bill also provided for entrance into the Berne Convention.

201. S. 3047, 74th Cong. (1935).

202. Duffy Bill, S. 3047, 74th Cong. (1935) (Sec. 17(b) amending Sec. 25 of Copyright Act of 1909).

203. 79 CONG. REC. 12,189-90 (1935).

204. Note, supra note 158, at 533-34. 
balance the various interests of consumers (who were concerned about innocent infringement) and publishers and authors (who faced an infringement policing problem) ${ }^{205}$ A new model of intellectual property pluralism emerged as an important feature of copyright law. It was clear that Copyright must reflect all interests: writers and composers, publishers and broadcasting companies, small licensees, and consumers. While it was possible to place the sound recordings debate-indeed, any copyright debate-within the framework of business versus consumer or large versus small, it was apparent that a broad array of competing interests needed to be taken into account.

State legislatures were less measured in their response to the sound recordings issue. In 1937, Nebraska passed the first anti-ASCAP legislation, "An Act Relating to Monopolies," making it unlawful for authors, composers and owners of copyrighted musical compositions to form an association when the members constitute a substantial number of persons within the United States who own or control these copyrights, identifying these as combinations in restraint of trade. ${ }^{206}$ All contracts made in violation of the Act were declared void and compositions could be performed in the state without regard to the copyright rights vested in the violators of the Act. Other state statutes, such as those of Washington and Tennessee, prohibited the fixing of blanket fees and permitted only collections of royalties when the rights were for compositions offered for single sale. ${ }^{207}$ By 1939 , anti-ASCAP legislation had been introduced in thirty-four states and had been enacted in seven of them. ${ }^{208}$

Florida's statute, for example, made it unlawful for owners of copyrighted musical compositions to combine in any association to fix license fees, declaring such a combination to be an unlawful monopoly and price fixing in restraint of trade unless this combination obtained a state license. ${ }^{209}$ Georgia and Louisiana imposed a substantial occupational tax upon those persons in the state collecting license fees. ${ }^{210}$ In Watson v. Buck, the Supreme Court decided the constitutionality of certain state statutes that regulated the music publication industry, determining price-fixing combinations of authors, publishers, and copyright owners to be illegal and in restraint of trade. These state statutes were upheld, and found not to be preempted by copyright. ${ }^{211}$

205. 79 CONG. REC. 12,189 (1935).

206. 1937 Neb. Laws ch. 138. See also Note, Musical Monopolies and Legislative Control, 53 HARV. L. REV. 458 (1940) (listing state anti-ASCAP legislation).

207. 1937 Tenn. Pub. Acts ch. 212; 1937 Wash. Sess. Laws ch. 218; 1937 Mont. Laws ch. 90; $1937 \mathrm{Neb}$. Laws ch. 138. Other states chose to regulate copyright in response to ASCAP. See 1939 Kan. Sess. Laws ch. 306; Wis. Stat. $§ 177.01$ (1939); 1939 N.D. Laws ch. 115; 1939 Vt. Acts \& Resolves 32, as well as one territory, 1939 Alaska Sess. Laws ch. 13; Wis. Stat. $§ 177.01(1939) ; 1939$ N.D. Laws ch. 115; 1939 Vt. Acts \& Resolves 32, as well as one territory, 1939 Alaska Sess. Laws ch. 13.

208. John Ryan, The Production of Culture In the Music Industry: The ASCAP-BMI CONTROVERSY 81 (1985).

209. Fla. Stat. ch. 17807 (1937).

210. Ga. Code Ann. § 92-512 (1936); La. Gen. Stat. Ann. § 8674.1 (1939).

211. Watson v. Buck, 313 U.S. 387 (1941). In Gibbs v. Buck, the Court granted an injunction to restrain the enforcement of the Florida Statute, 307 U.S. 66 (1939). 
ASCAP was severely wounded by these political attacks. By 1939, anti-ASCAP radio broadcasting interests determined that the time was ripe to challenge its control over sound recordings. They founded Broadcast Music Incorporated (BMI) as an alternative to ASCAP. However, BMI found it difficult to purchase music since so much had already been contracted to ASCAP. It began to sign up unusual, previously ignored music, including Latin American music and works of ethnic Italian and Jewish composers. It also signed African-American musical compositions, such as those performed by Duke Ellington. ${ }^{212}$ Jazz became an important part of BMI's catalogue. Quite suddenly, music which had not previously been heard on the airwaves became commonplace. While ASCAP would reassert its market power through the 1940s, an increasingly diverse public culture emerged as a result of this controversy. ${ }^{213}$

Congress, of course, had its own sense of the ASCAP debate. It ultimately saw that it had the responsibility to balance competing interests, not to add to the arsenal of antitrust tools. In the wake of the New Deal, economist John Kenneth Galbraith would argue that one of its legacies was the idea of "countervailing power," the pitting of one interest against another with the government serving as a mediator. ${ }^{214}$ In the case of the 1976 Copyright Act, such a mix of compulsory licensing, sanctions, exclusive rights and fair use would be its centerpiece.

\section{B. Private Ordering and Industrial Design}

If the battle raged within Congress to unravel the conundrum of ASCAP's monopoly power, there was much more sympathy for attempts to create trade association guidelines to enforce standards of competition, excluding or disciplining marginal competitors. ${ }^{215}$ During the New Deal era, the associational ideal - the idea that a more ordered economy might be established through cooperation between competitors or, perhaps, even including labor-increasingly took hold. As historians have shown, support for the associational ideal did not necessarily mean a sharp break with Progressive Era politics. After all, Progressive Era reformers sought economic order through planning and scientific management, and fostered associations as an instrument of economic mobilization during World War I. ${ }^{216}$ Such mechanisms nonetheless raised issues about restraint of trade and, more importantly, often foundered upon enforcement issues. As one trade official remarked, "we have a code of ethics ... something like the Ten Commandments, a

212. Louis Barfe, Where Have All The Good Times Gone? The Rise And Fall Of The RECORD INDUSTRY 145-6 (1988); JOHN STORM ROBERTS, THE LATIN TINGE: THE IMPACT OF LATIN AMERICAN MUSIC ON THE UNITED STATES 111 (2d ed. 1999).

213. John Ryan, The Production of CUlture In the Music Industry: THe ASCAP-BMI CONTROVERSY 83-5, 109-12 (1985).

214. John Kenneth Galbraith, American Capitalism: The Concept of Countervalling POWER (1952).

215. COLIN Gordon, NeW DeAls: Business, LABOR, AND Politics IN AMERICA 1920-1935 134 (1994).

216. Alan Brinkley, Prosperity, Depression, and War 1920-1945 in THE NEW AMERICAN HISTORY 127 (Eric Foner, ed., 1990). 
nice thing to refer to but something which we do very little about."217

To foster the production of mass-produced clothing better protection needed to be afforded to industrial design. America, proponents of industrial design protection argued, should not be dependent upon Paris. ${ }^{218}$ By World War I, the apparel industry was the United States' third largest trade after steel and oil. ${ }^{219}$ In New York, for example, over fifteen thousand firms produced clothing. ${ }^{220}$ Partly in response to a growing problem of overproduction, the fashion industry, with its focus on new designs, created a mechanism for planned obsolescence of clothing.

Style creation was a costly process. It entailed the gathering of information from far away design centers such as Paris, the cost of creating multiple patternsof which only a few might become popular with the public - and the additional investment required to market a novel design. Recognizing the substantial costs involved in originating designs, competitors often seized upon piracy to achieve a competitive footing. Mass-production of clothing allowed competitors to make lower priced knock-offs with the under-utilized industrial manufacturing capacity that existed in the 1930s. Designers responded to this competitive pressure by fostering product differentiation in the form of new styles-leading to a shorter style life for the clothing to the detriment of consumers.

Yet information about style circulated readily, and competitors-as well as potential consumers-became aware of innovations in design almost as soon as they were released. Accordingly, designers were allowed little time to enjoy the fruits of their labor before nearly identical competing items appeared on the market. This economic dynamic was familiar to New Deal observers. As producers sought to establish monopoly advantages by making clothing with unique styles, cut-throat competition created downward pressure for prices. There was a real concern that design piracy was injurious not just for designers, but for the entire textile industry.

Beyond the fashion industry, the late 1930s and early 1940s was the golden age of industrial design. Major figures such as Raymond Loewy, Walter Dorwin Teague, Norman bel Geddes, and Henry Dreyfuss combined aesthetics and mechanical engineering to transform everyday material objects. ${ }^{221}$ These designers promised a new, streamlined America, which might capture the imagination of consumers. Despite its growing importance, industrial design existed in an interstitial space between intellectual property regimes. ${ }^{222}$ Design patent was a poor choice for protection since it embodied the higher standards of patent

217. GORDON, supra note 215 , at 137.

218. Designers Seek Aid in Copyright Laws, N.Y. TrMES, Mar. 23, 1941, at F7.

219. LEACH, LAND OF DESIRE, supra note 22, at 93.

220. Id. at 94 .

221. See generally RAYMOND LoEWy, Industrial DEsign (1979); JeFFrey L. MEIKLE, TWENTIETH CENTURY Limited: INDUSTRIAL DESIGN IN AMERICA, 1925-1939, (2d ed. 2001); DAVID A. HANKS AND ANNE HOY, AMERICAN STREAMLINED DESIGN: THE WORLD OF TOMORROW (2005); J. STEWARt JOHNSON, AMERICAN MOdern 1925-1940: DESIGN FOR A NEW AGE (2000); GLENN PORTER, RAYMOND LOEWY: DESIGNS FOR A CONSUMER CULTURE 11-18 (2002).

222. The problem of industrial design's awkward place between regimes still exists. For a proposed solution, see J.H. Reichman, Legal Hybrids Between the Patent and Copyright Paradigms, 94 COLUM. L. REV. 2432 (1994). 
protection. Often industrial designs were less innovative, and could not meet patent law's invention and novelty requirements. They often included unprotectable functional elements. ${ }^{223}$ It was estimated that $90 \%$ of patent applications for industrial design were refused. ${ }^{224}$ Moreover, patent was a slow, cumbersome, and expensive process. Around 1940, it required almost four months to secure a design patent. ${ }^{225}$ In the period between application for a design patent and issuance, a design might be pirated.

Trademark or unfair competition protection was unavailable unless competitors sought to deceitfully palm off their goods as those of the original designer. ${ }^{226}$ Copyright was the most promising doctrine for protection, but the 1909 Copyright Act provided for registration of designs only insofar as they were used as a "design for works of art," which meant a painting, drawing, or sculpture. ${ }^{227}$ While the Supreme Court in Bleistein v. Donaldson Lithographing Co. decided not to distinguish between works of higher art and commercial drawings, it was also true that drawings, as a category, were privileged with protection. ${ }^{228}$ Other applied arts fell outside the ambit of the copyright statute. ${ }^{229}$

In the 1929 case of Cheney Bros. v. Doris Silk Co., Judge Learned Hand recognized the harm done to the manufacturer of originally designed clothing by a competitor who copied his design, but failed to provide relief. ${ }^{230}$ Judge Hand cabined the precedent created by International News Service v. Associated Press. ${ }^{231}$ That decision, the Court held, applied to a specific set of facts, and did not lay down a general principle of finding misappropriation through a theory of unfair competition whenever an injury is done to an individual who has invested labor in a mental product. Judge Hand stated that it was impossible to decide to extend protection when even the most rudimentary rules governing intellectual property, such as the duration of the rights, were not spelled out by a statute. Cheney Bros. seemed to beg for statutory intervention.

It is not surprising, then, that Congress took up the issue of protecting industrial design. But competing interests paralyzed Congressional action. ${ }^{232}$ Between 1914 and 1939, Congress considered some twenty-one bills on design protection. ${ }^{233}$

223. Sylvan Gotschal \& Alfred Lief, The Pirates Will Get You: A Story of the Fight FOR DESIGN PROTECTION (1945).

224. C.F. Hughes, The Merchant's Point of View, N.Y. TIMES, Apr. 12, 1936, at F9.

225. Designers Seek Aid in Copyright Laws, N.Y. TIMES, Mar. 23, 1941, at F7.

226. See, e.g., Kemp \& Beatley v. Hirsch, 34 F.2d 291 (E.D.N.Y. 1929) (declining to obtain unfair competition protection for dress design).

227. 35 Stat. 1077 (1909), 127 U.S.C. § 5(g) (1926).

228. 188 U.S. 239 (1903).

229. Protecting industrial design under existing copyright law remains a problem. Recently, a law to protect fashion designs was introduced in Congress, H.R. 5055, 109th Cong. (2006) to amend Title 17 , section 1301, providing for a three year term of protection and a lower threshold of originality for fashion designs.

230. 35 F.2d 279 (2d Cir. 1929), cert. denied, 281 U.S. 728 (1930).

231. 248 U.S. 215 (1918).

232. CONG. REC. 10,419 (1930) describes the pressing need for protection of industrial design after the handing down of Cheney Bros. v. Doris Silk Co.

233. Note, Self-Protection of Design Creation in the Millinery Industry, 49 YALE L.J. 1290, 1293 
None passed. Two of these legislative initiatives were particularly significant. The Hebert Design Protection Bill provided for the registration in the Copyright Office of a design that had originality and novelty, though lacking in invention. A certificate of registration was to be issued within seven days of application. Nevertheless, it failed due to significant opposition on the grounds that it fostered monopoly. ${ }^{234}$

The most notable Congressional statutory initiative was the Vestal Design Copyright Bill, which passed the House in July $1930 .^{235}$ It provided protection for industrial patterns, shapes and forms. Those who copied these elements for commercial purposes or dealt in unauthorized copies would be subject to various sanctions, such as injunction, suit for accounting, and action for treble damages. ${ }^{236}$ An exemption was provided for private dressmakers, although this provision was later removed. ${ }^{237}$ To obtain protection, the designer would have had to show: (1) actual embodiment in a manufactured product; (2) affixation of the mark "Design Copyright" or "D.Copr."; (3) that the design was used in commerce; and (4) an application for registration within six months of sale. The bill provided for an initial two year term of protection with an extension to eighteen years upon payment of a fee.

The Vestal Design Bill was the result of significant lobbying by various trade associations. ${ }^{238}$ It was drafted so as to take into account competing interests. Important members of the drafting committee included Sylvan Gotshal, the representative of the Design Piracy Committee of the Silk Association of America, a representative of the Merchants Association of New York, and a representative of the American Bar Association. ${ }^{239}$ Backers of the bill insisted that they were asking for no more than the same sort of relief granted to inventors of mechanical inventions. ${ }^{240}$ Arguing for the necessity of the bill, the committee claimed that the response of the courts after Doris Silk and the absence of FTC intervention, had left numerous industries vulnerable to piracy. ${ }^{241}$ Yet after heated debate, the bill

\section{n.20(1939-1940).}

234. See, e.g., Design Protection: Hearings Held Before the H. Comm. on Patents, 72nd Cong. $62-$ 63 (1932) (memorandum submitted by the Committee on Copyrights of the Association of the Bar of the City of New York); S. REP. No. 1627, pt. 2, at 2-3 (1931).

235. H.R. 11852, passed July 2, 1930. Vestal had sought to introduce bills to shift design protection from patent to copyright, introducing bills on December 5, 1924 (H.R. 10351, 68th Cong. (2d Sess. 1924)); on December 21, 1925 (H.R. 6249, 69th Cong. (1st Sess. 1925)); and a revised bill on June 28, 1926 (H.R. 13117, 69th Cong. (1st Sess. 1926)). However, the Vestal Design Copyright Bill would warrant significant debate beginning in the 1930s.

236. Id. at $\$ 10$.

237. Id. at $\S 9(\mathrm{~b})$.

238. Most notable among the organizations promoting the protection of industrial designs was the Design Copyright League; but trade association supporters included the Silk Association of America, the Lace Manufacturers of America, and the Fashion Originators' Guild. See To Request Report on Design Measure, N.Y. TImES, Dec. 18, 1932, at N6; see also Fight Shoe Style Piracy, N.Y. TIMES, Dec. 11, 1932, at N6 (on support of shoe industry).

239. The Vestal Bill in a Nutshell (1930), pamphlet found in the Albert H. Vestal Papers, Box \#4, State of Indiana Library.

240. Id.

241. Id. 
ultimately failed to pass the Senate. Retailers, who believed that they would shoulder the burden of determining whether an article of clothing infringed, strongly opposed the Vestal Bill. ${ }^{242}$ There was concern over its scope because it covered every sort of manufacture. ${ }^{243}$ Certain industries, such as the automotive industry and glass container manufacturing, had specifically asked to be exempt from its regulation. ${ }^{244}$

Even a more circumscribed version of the Vestal Design Bill, which might apply only to textiles, lighting, and a limited number of other forms of manufacture, could not claim to be anything other than a Congressional extension of monopoly for particular industries. The requirement that there be "embodiment in a manufactured product" presumed the existence of a manufacturer. Unlike copyright's lone author or patent's lone inventor, no image of the lone designer could be conjured up by the bill's backers. Ultimately, Senate critics contended, "the consuming public will be compelled to pay for these monopolies and all the numerous suits. $" 245$

The absence of Congressional protection led to alternative schemes for industrial design protection. Various National Recovery Administration (NRA) codes contained design piracy provisions. The NRA was established as part of the massive National Industrial Recovery Act (NIRA), passed on June 16, 1933, which was meant to jump-start the stagnant United States economy. ${ }^{246}$ It included federal regulation of employee hours and wages; the creation of the NRA; and the foundation of the Public Works Administration to embark upon an ambitious program of public construction. The NRA was the most controversial component because it brought government-sponsored cartels into being. Through the NIRA's Title I, statutory authority was granted to the President to approve codes of fair competition submitted by industry trade groups. The codes were meant to establish commercial morality, to promote competition and to avoid rent-seeking monopoly. While little guidance was given in terms of the specific provisions of the codes, they generally provided for industry-specific price-fixing, wage, and production

242. Legislation-The Vestal Bill for the Copyright Registration of Designs, 31 COLuM. L. REV. 477, 489-90 (1931). See Committee Reports of the Section of Patent, Trade Mark and Copyright Law of the American Bar Association (Aug. 1933), 15 J. PAT. OFF. SOC'Y 796, 807-08 (1933) (describing the objections of the Retail Dry Goods Association); Dry Goods Men Aid Stabilization Plan, N.Y. TIMES, Feb. 8, 1930, at 30; The Merchant's Point of View, N.Y. Times, Jan. 4, 1931, at N19.

243. Ultimately, there was a move to limit it to five classes of industrial products: textiles, lace, and embroideries; furniture; lamps and lighting fixtures; footwear; and jewelry and articles made of precious metals. Applied Art, N.Y. TiMES, Oct. 30, 1932, at X10.

244. GOTSHAL \& LIEF, supra note 223 , at 40 . In requesting the exemption, the automotive manufacturers claimed that there was little theft of designs in the automotive industry. See Design Copyrights Fought as 'Unjust', N.Y. TIMES, Jan. 9, 1931, at 26.

245. GOTSHAL \& LIEF, supra note 223, at 40-41.

246. On the history of the NRA, see HAWLEY, supra note 44; COLIN GORDON, NEW DEALS: Business, LABOR, AND POLITICS IN AMERICA 1920-1935 (1994); BERNARd BELLUSH, THE FAILURE OF THE NRA (1975); DONALD BRAND, CORPORATISM AND THE RULE OF LAW: A STUDY OF THE NATIONAL RECOVERY AdMINISTRATION (1988); DANIEL Fusfeld, THE ECONOMIC THOUGHT OF FrANKLIN D. ROOSEVELT AND THE ORIGINS OF THE NEW DEAL (1956); ROBERT HIMMELBERG, THE ORIGINS OF THE

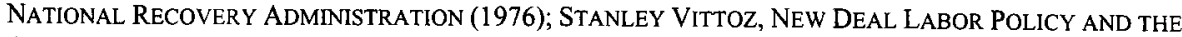
AMERICAN INDUSTRIAL ECONOMY (1987). 
controls. Fair practice standards were supposed to halt the deflationary spiral. If an industry failed to promulgate a code, the President was authorized to do so. The NIRA reflected a political economy of industrial self-government, which was corporativist in nature. It enlisted labor, industry, and consumer representatives in code making.

In what seemed like a mirror of the traditional Constitutional tripartite separation of powers, each of these three interest groups-labor, business, and consumer - were to bring something different to the negotiating table. Labor would contribute a disciplined workforce in exchange for opportunities in collective bargaining. Business would balance over-competition and monopoly capitalism. Consumers were assured of greater purchasing power in a setting of industrial peace. In the words of Rexford Tugwell, the NIRA embodied the idea that "cooperation and not conflict" was preferred. ${ }^{247}$ The implications of the NRA for intellectual property law were important. By creating a government-sponsored cartel, it set aside the traditional limitations on the restraint of trade, and, indeed, it called for an industry-wide combination.

While Congress and the courts were still struggling with anti-monopoly rhetoric, New Deal lawyers inserted design anti-piracy provisions into NRA codes. Take, for example, the code of the China Ware and Porcelain Manufacturing Industry, which barred the "copying of prints, or decalcomania or hand painted patterns or shapes, of any American pottery of China manufacturers which is a new and original design and not an adaptation of a foreign or domestic design." 248 Other design protections were provided for the upholstery and drapery industries, the handkerchief industry, and tool and die industry, among others. ${ }^{249}$ The silk industry's existing design trade regulation was granted a fuller legal status within the NRA Silk Textile Industry code, promulgated in October 1933. According to the code's section on competitive practices, "no employer shall take orders for, or print, or jacquard weave any design not registered with the Textile Design Registration Bureau of the Silk Association of America."250

However, the opportunity for industrial design regulation under the umbrella of the NRA would be limited. ${ }^{251}$ The NIRA had come under attack from various groups, from old Progressives who chaffed at the sponsorship of cartels to labor organizers who remained skeptical about the presumed shared interest of labor and capital to conservatives who saw the specter of socialism haunting America. The NIRA was both chaotic in its administration and ineffective. Consumer prices increased while wages remained low. Outside the Roosevelt administration, few mourned the NRA when the Supreme Court struck down the NIRA in May 1935 on

247. HAWLEY, supra note 44 , at 28 .

248. Silk Textile Industry Code, in LEWIS MAYER, A HANDBOOK OF NRA 782-88 (2nd ed. 1934).

249. Karl Fenning, N.R.A. Codes, 16 J. PAT. OFF. SOC'Y 189, 199-202 (1934).

250. Silk Textile Industry Code, supra note 248 , at 782-88.

251. Nevertheless, the American Bar Association Committee on Protection of Designs found the results, especially in the silk industry, "highly satisfactory." Committee Reports of the Section of Patent and Trade Mark and Copyright Law of the American Bar Association (August 1935), 17 J. PAT. OFF. SOC'Y 645, 663-64 (1935). 
Constitutional grounds. ${ }^{252}$ In the words of Justice Benjamin Cardozo, the NIRA represented "delegation run riot." 253

Absent legislative regulation of industrial design, various industries sought to create their own self-help mechanisms. The first of these was established in 1928. The Silk Association of America, a trade association of fabric manufacturers, sought to protect designs in fabric prints commonly used in clothing. A copy was made of each design and placed in a central clearing house. Each design was registered for two years but later reduced to one year and, ultimately to six months (a term considered the equivalent of the fashion industry's season). New designs would be compared to those previously filed. A decision concerning the originality of the new design would be made within forty-eight hours of filing. The standard for infringement was whether the two designs were seen as similar from the viewpoint of the ordinary observer. Silk printers agreed to manufacture only those designs registered with the Association. But enforcement was far from perfect. Without some kind of court-enforced sanction, and with increasing pressure on the industry, the system really could not work. ${ }^{254}$

The millenary industry also turned to self-help regulation. A substantial majority of the manufacturers of originally-styled ladies hats combined to form the Millinery Creators' Guild. The Guild provided for registration of original hat designs. Once registration was certified by the Guild, with originality determined by a Guild committee, unauthorized copies were deemed to be pirated. Originality was not a terribly high threshold, and even minor alterations might still be considered original. Members agreed not to copy registered designs, nor would they sell their hats to retailers who had not signed a Guild pledge of cooperation, which included a promise not to sell pirated hats and to "recognize the Guild members' property rights in original designs." Over 1,600 major retailers signed the pledge of cooperation. ${ }^{255}$

Suit was brought against the Guild by the Federal Trade Commission for engaging in unfair competition in violation of $\S 5$ of the Federal Trade Commission Act. ${ }^{256}$ The Court found that the Guild did violate antitrust laws by confining competition in questions of price, quality, or service. Interestingly, the fact that the Guild through concerted action established such restrictions was not itself illegal, since beneficial combinations were lawful. But the Court was troubled by the granting of an extra-official monopoly to a creator whose idea was unworthy of a patent. Congress had established the standards for intellectual property protection, and only those ideas sufficiently original would receive exclusive rights. Using a self-help mechanism, the Guild sidestepped this quid pro quo. The Court

252. A.L.A. Schechter Poultry Corp. v. United States, 295 U.S. 495 (1935).

253. Barry Cushman, Rethinking tHe New Deal COURT: THE Structure of a Constitutional Revolution 34-38 (1998); G. EdWARd White, The Constitution and the New DEAL 108-14 (2000).

254. GotshaL \& LIEF, supra note 223 , at $47-59$.

255. Millinery Creators' Guild, Inc. v. Federal Trade Comm'n., 109 F.2d 175, 176 (2d Cir. 1940). See also Note, Self-Protection of Design Creation in the Millinery Industry, 49 YALE L.J. 1290, 1293-94 n.27 (1939-1940).

256. 15 U.S.C. $\S 45(2000)$. 
recognized the costs of style piracy, but the Guild's actions still did not constitute a "socially desirable" goal. ${ }^{257}$

If, as with sound recordings, Congress could not yet strike the balance for intellectual property industrial pluralism, neither could extra-official cartels fill the void in the case of the milliners. Nevertheless, both cases show the way Congress was ready to use cartels in an increasingly complex fashion as a fulcrum point for balancing the concerns of competing interest groups. Intellectual property was very much on the agenda of economic policy makers.

By the end of the New Deal period, much had changed. Trademark had been transformed from a common law bar to palming off into a proprietary right on its own terms. Congress had designed a national system for the protection of marks, which would be policed through infringement suits, and which might be used as part of a broader Keynesian economic policy to stimulate the economy as a whole. Copyright had shifted its terrain from the romantic image of authorship to the regulation of competing interests in mass media and industrial design. Rights granted to sound recordings and fashion design were part of a broader political economy. Copyright's new-found purpose was to promote the aggregate economic interests of an emerging industrial economy. In addition, its legal mechanisms had changed a great deal from copyright's nineteenth-century antecedents rooted in literary property to an array of twentieth-century provisions, such as those relying upon compulsory licensing, pooling of copyrights, extra-official trade organizations, and government mediation of competing interests.

Perhaps New Deal lawyers simply wished to prod a sluggish economy or to establish intellectual property systems which were better ordered than the ones they inherited. An unintended consequence of these trademark and copyright interventions, however, was to create a much more robust public sphere and a new definition of citizenship. The founding document of the New Deal consumer republic was the Lanham Act. In the age of mechanical reproduction where mass media was crucial in shaping everyday habits, copyright served to establish an ever more varied public sphere with a vast array of music and fashion designs. This new public sphere was characterized by unheard of cultural diversity. ${ }^{258}$

257. Millinery Creators' Guild, 109 F.2d at 177-78. But see Wm. Filene's Sons Co. v. Fashion Originators' Guild of Am., Inc., 90 F.2d 556 (1st Cir. 1937) (decided differently even though the case was based upon nearly identical set of facts as those of Millinery Creators' Guild).

258. I am drawing here upon Jürgen Habermas' idea of the public sphere (THE STRUCTURAL TRANSFormation OF THE PUBlic SPHERE (1989)), upon which French historians have been drawn extensively; see, e.g., KeITH MichaEl BAKER, INVENTING THE FRENCH REVOlUtion (1990). If we consider, as Bruce Ackerman has in elite Constitutional terms, United States legal history as being defined by three constitutional moments, then each of these has its own relationship to the public sphere. The American Revolutionary and Constitutional period of the late eighteenth century established a public sphere of the coffee house and extra-official street actions. As Elizabeth Clark, David Brion Davis, and others have shown, the mid-nineteenth century reform movements - the women's rights movement and abolitionism, through print culture including prints and novels-promoted an empathic relationship towards a subordinate social group. New Deal citizenship marked the beginning of a citizenship grounded upon appropriation of the symbols and technologies of a trans-national public sphere, often pre-existing commercial symbols, in order to shape individual and collective identities. 


\section{PATENTS AS CORPORATE PROPERTY}

Anti-monopolistic rhetoric did not completely disappear as the New Deal recast intellectual property law; it shifted meaning differently in various regimes. Within the arena of trademark law, as we have seen, a new rational theory of trademark was able to dislodge the idea that trademark infringement required a showing of fraud within a shared market. The Lanham Act recognized proprietary rights in the trademark itself. Although monopoly remained a lingering trademark issue, it quietly receded from the focus of intellectual property policy debates. In the 1930s and 1940s, courts sought to balance economic costs and benefits in order to justify the monopoly in the symbolic property of trademarks. The benefits were identified with a Keynesian posture of stimulating the appetite for consumer goods in order to sustain the economy as a whole. Over time, however, these property rights became seen as normative.

Similarly, copyright's battle over sound recordings quieted to a low hum. Following the New Deal approach of fostering industrial pluralism, the issues were to be resolved in a way that would take into account the many competing interests involved in this issue-artists and musicians, music publishers and the recording industry, hotel and restaurant owners, and ordinary consumers. Copyright legislation ultimately reflected a negotiated settlement intended to foster expanding domestic and international media markets. Recognizing the monopoly character of copyright protection, the legislative outcome would create exceptions to this exclusivity by allowing innocent infringement and establishing compulsory licensing schemes, while allowing proprietary owners to exploit copyrighted material for their-and presumably the public's - benefit.

By the same token, the New Deal should have recognized the particular importance of patents to a broad economic recovery. Patents would have fit neatly into the overall Roosevelt industrial policy since new technological discoveries might have resulted in new consumer goods. Moreover, since in the early years of the New Deal, the National Recovery Act established uniform pricing, the avenue for competition became the character of the goods-and patented improvements, like trademarks, might have served to distinguish one product from another. ${ }^{259}$ Nevertheless, New Deal courts continued the Progressive Era courts' tradition of hostility to patents, often invalidating them on such grounds as prior anticipation, lack of invention, or failure to comply with various formal statutory requirements. ${ }^{260}$ Patents were seen as a form of corporate property granted as monopoly. Patent pools and patent tying mechanisms raised concerns as potential violations of antitrust law. Courts spoke of "a tension between a strong public policy against monopoly and a desire to encourage inventions which will benefit the public."261

However, beyond court decisions, the Roosevelt administration found itself

259. See generally Fenning, supra note 249.

260. Robert P. Merges, Commercial Success and Patent Standards: Economic Perspectives on Innovation, 76 CAL. L. REV. 805, 818 (1988).

261. Ashcroft v. Paper Mate Mfg. Co., 434 F.2d 910, 912-13 (9th Cir. 1970). 
searching for ways to radically alter the patent system and curb the protections granted to patent holders. Among its many proposed reforms was the establishment of open patent pools, compulsory licensing, and regulatory supervision of patent use by the FTC. Ultimately, while there was little Congressional legislation, the FTC did aggressively pursue anti-competitive use of patents.

\section{A. Challenging the Market Power of Patents}

At the core of the Constitutional provision authorizing Congress to enact patent law is the idea of securing for inventors "exclusive right to their ... discoveries," which restrains others from making, using or vending an invention. ${ }^{262}$ Patent grants provide for the right of exclusion absent the permission of the patentee. ${ }^{263}$ In other words, the "language of complete monopoly is employed."264

But how complete was this monopoly? In the aftermath of the passage of the 1890 Sherman Act, patent was said to have its own inherent limitations, such as scope and term, to its monopoly power. Indeed, there was originally a presumption that patent owners were exempt from related antitrust actions, and for two decades after the passage of the Sherman Act, no patent cases were brought under the statute. By the early $1920 \mathrm{~s}$, however, courts began to distinguish between the monopoly in the right to exploit an invention and the use of patent to engage in monopolistic or anti-competitive behavior in markets. ${ }^{265}$

This shift might be seen in a series of court cases which served as the battleground for the difficult question of whether the Sherman Act might be used to bar price-fixing through the mechanism of patent pools. Corporations were accused of wrongfully leveraging patents for economic power through the crosslicensing mechanism of the patent pool, whereby a number of entities enter into a mutual agreement to cross-license all patents. The participants in patent pools might vary. Sometimes these pools were organized for the sake of only a select few dominant firms in a given market, and sometimes the agreement was more inclusive. Such cross-licensing schemes were intended to make industrial knowledge common property for a limited number of economic actors. ${ }^{266}$ Patent pools thereby could be used to restrain trade in a number of ways, such as restricting conditions for use, suppressing new patents, and limiting competition

262. U.S. CONST. art. I, $\S 8$.

263. Bloomer v. McQuewan, 55 U.S. 539, 549 (1853).

264. Continental Paper Bag Co. v. Eastern Paper Bag Co., 210 U.S. 405,424 (1908).

265. Willard K. Tom \& Joshua Newberg, Antitrust and Intellectual Property: From Separate Sphere to Unified Field, 66 ANTITRUST L.J. 167, 168 (1997) (identifying early period from 1890 to almost 1920 when courts viewed patent as granting exemption from anti-monopoly prosecution). The distinction between monopoly rights in the invention and the exercise of market power remains contested legal terrain. See Illinois Tool Works, Inc. v. Indep. Ink, Inc., 547 U.S. 28 (2006) (holding that there is no presumption that patent rights confer market power).

266. Hamilton, PATENTS AND FREE ENTERPRISE: InVESTIGation OF CONCENTRATION OF ECONOMIC POWER, TEMPORARY NATIONAL ECONOMIC COMMITTEE, MONOGRAPH 3177 (1941). 
through barricading the market against new entrants. ${ }^{267}$

The Supreme Court first fully addressed the issue of whether patent pools violated antitrust law in the 1902 case E. Bement \& Sons v. National Harrow Co. ${ }^{268}$ A number of different firms created a patent pool consisting of eighty-five patents dealing with harrows, agricultural devices designed to spread material on fields. The pool grew to comprise twenty-two firms and represented over ninety-percent of all manufacturing and sales for harrows. Those firms entering into the pool were charged fixed prices for licensed products, agreed to stipulations obligating licensees not to challenge the patents within the pool, and required licensees to sell only the licensed products. The Court decided these restrictions were lawful since the object of patent law was monopoly, and patent owners had the right to specify the prices for their inventions. ${ }^{269}$ Like patents, patent pools were exempt from antitrust actions. Indeed, the Court found a positive justification for patent pools since patent pools provided a mechanism for competitors to curb infringement, and thus limit costly litigation. . $^{270}$

National Harrow was seen as a debacle by those seeking to limit the market power of patents. Critics argued that the Court failed to distinguish between the legal monopoly of patents and the "monopoly of monopolies"-the patent pool. ${ }^{271}$ Just a decade after National Harrow, the Supreme Court reversed its position. In 1912, in Standard Sanitary Manufacturing Co. v. United States, a pooling arrangement was found to violate antitrust laws. ${ }^{272}$ In this case and its progeny, the patent pool was found to be not per se objectionable. However, patent pools were characterized as instruments used to fix prices and to limit industrial output. ${ }^{273}$ Courts increasingly found that the use of patents might be subject to an anticompetition limitation. ${ }^{274}$

Even earlier, in a 1908 case, Continental Paper Bag Co. v. Eastern Bag Co., the Supreme Court addressed the issue of whether there might be equitable limits on patents pursuant to the Constitutional requirement "to promote science and the useful arts."275 In the case, an infringing user of a paper bag-manufacturing machine claimed that patent's exclusive rights pertained only to the right of restraint for a competing use. Since the patent owner denied hitherto using the patent, he claimed that there should be an equitable defense to the infringement suit. The Court rejected this argument, stating that the right to suppress the use of

267. Irving I. Schachtel, Patent Pools and the Federal Anti-trust Laws, 5 LINCOLN L. REV. 7 (1931-32).

268. 186 U.S. $70(1902)$.

269. Id. at $755-56$.

270. Id. at 756 .

271. See, e.g., Irving I. Schachtel, Patent Pools and the Federal Anti-trust Laws, 5 LINCOLN L. REv. 7, 7 (1931-1932); Patent Pools and the Sherman Act, 40 YALE L.J. 1297, 1297-1303 (1931).

272. 226 U.S. 20 (1912).

273. Id. at $48-51$.

274. Richard J. Gilbert, Antitrust for Patent Pools: A Century of Policy Evolution, 3 STAN. Tech.

L. REV. 3 (2004).

275. 210 U.S. 405 (1908). 
other private parties was "the very essence of the right conferred by the patent."276

Nonetheless, the Court also determined that there might be an instance where "the rights of the public were involved," such as diminished supply or increased prices. $^{277}$ The Court in Continental Paper Bag preserved an opportunity for intervention in order to follow the constitutional mandate to promote the progress of science and the useful arts. Earlier Supreme Court decisions uneasily sought to balance the right of licensing under patent with concerns about anti-competitive actions on the part of patent owners. Prosecution for anti-competitive actions would take place if the violation was egregious enough. ${ }^{278}$

A valid patent did not immunize patent holders from antitrust actions. According to a string of Supreme Court decisions following Continental Paper $B a g$, a patent granted the patentee the right to exclude others, but did not establish any per se right for the patentee to make, use, or sell his own invention. ${ }^{279}$ Such rights were granted under the common law, not arising under the federal patent laws, and the use of one's own invention was permitted only insofar as it did not violate valid federal or state regulations. ${ }^{280}$ According to Judge Learned Hand, who reiterated this legal rule in 1947, possession of patents did not provide "any immunity from $\S 1$ of the Sherman Act" for the freedom to make and sell goods was "derived from the common law, not from the patent law." 281

In the Gasoline Cracking case, the Supreme Court decided that the limited monopolies granted to patent owners did not establish an exemption to antitrust legislation when patent licensing agreements were entered into in order to limit the supply or fix the price of goods entering into interstate commerce. ${ }^{282}$ Under certain

276. Id. at 429 .

277. Id.

278. See generally Standard Sanitary Mfg., 226 U.S. at 20 (patent holders requiring as a condition for sale sanitary enamel ware companies' agreement to sell at fixed prices found to violate Sherman Act).

279. See Motion Picture Patents Co. v. Universal Film Mfg. Co., 243 U.S. 502, 517-518 (1917) (upholding Congressional statutory power to limit price fixing by patentees); U.S. v. United Shoe Machinery Co. of New Jersey, 247 U.S. 32, $57-58$ (1918) (patentee has the power of granting license selectively choosing persons and terms, but he cannot grant the title and retain the incidents of it); Long v. Rockwood, 277 U.S. 142, 147-148 (1928) (the power to exclude others, granted by the United States to the patentee, subserves a definite public purpose); Crown Die \& Tool Co. v. Nye Tool \& Machine Works, 261 U.S. 24, 34-36 (1923) (patentee is granted right to exclude others from making or using invention, not granted right to make or use invention himself); Special Equipment Co. v. Coe, 324 U.S. 370,379 (1945) (the monopoly of a patent affords no defense for violations of the Sherman Act); U. S. v. Line Material Co., 333 U.S. 287, 316-317 (1948) (patent is privilege conditioned by a public purpose and is subject to general legal limitations on contract).

280. Continental Paper Bag, 210 U.S. 405 (1908)

281. Pfotzer v. Aqua Sys., Inc., 162 F.2d 779, 784 (2d Cir. 1947); cf. United States v. E.I. Du Pont de Nemours \& Co., 118 F. Supp. 41 (D. Del. 1953), aff d, 351 U.S. 377 (1956) (mere possession of a validly issued patent may not be relied upon by plaintiff to establish violation of Sherman Act).

282. Standard Oil Co. (Indiana) v. United States, 283 U.S. 163, 169 (1931). But see Virtue v. Creamery Package Mfg Corp. \& Owatonna Corp., 227 U.S. 8 (1913) (simultaneous suits by two companies for patent infringement does not constitute conspiracy to restrain trade in violation of the Sherman Antitrust Act); United Shoe Machinery Corp. v. United States, 258 U.S. 451 (1922) (lease provisions preventing lessees from obtaining competitors' machinery without forfeiting license to use patent owner's machinery found to violate Clayton Act). 
circumstances, the Court determined, patent pooling arrangements and joint agreements with onerous licensing fees, and with potential impact upon consumer prices, might lead to the restraint of trade.

Patent pooling was practiced in a number of industries, especially pharmaceuticals. However, the most controversial instance of its use was by the Radio Corporation of America, which along with General Electric, Westinghouse, and American Telephone and Telegraph, had established a patent pool of devices to use or sell radios. Consisting of some 3,500 patents by 1930, this pool encompassed virtually every important radio patent and was said to stifle competition. A consent decree issued by a Federal Court in 1932 ultimately broke up the pool in order to enable independent manufacturers to obtain licenses from individual patent holders. ${ }^{283}$

By the end of World War I, the shift was clearly in the direction of limiting the power of patents. This reflected legal thinking that increasingly associated cartels with non-democratic, even militaristic, societies such as Germany and Japan. ${ }^{284}$ Political economist Robert A. Brady, a Veblen disciple with deep roots in American agrarian radicalism, saw patent pooling as part of a larger process of building cartels similar to those in Germany, which relied upon control of technical production in large laboratories, interlocking directorates, and shared market interests. ${ }^{285}$ Brady portrayed the creation of "monopoly-oriented business which attempts to evade democratic restraints" as occurring with patent pooling and with corporate control of new electronic media such as radio with its potential as a source of propaganda for the masses. ${ }^{286}$ Brady's cautionary tales about patent and copyright reflected his strong commitment to radical politics. But the connection he drew between intellectual property, anti-fascism, and the threat of monopoly was commonplace across the political spectrum for those interested in constructing a democratic political economy.

Brady marked the apotheosis of the New Deal concern with the monopoly power of patent. But certainly, even earlier in the twentieth century, there was increasing scrutiny of the market leverage granted to the holders of patents. Almost immediately after the passage of the Sherman Act in 1890, courts had examined the legality of tying arrangements. ${ }^{287}$ However, the Supreme Court upheld the right of those granted a patent to predicate the purchase of a patented machine upon buying non-patented staple commodities, and thereby privileged the

283. United States v. Radio Corp. of America et al., Decree in Federal District Court for the District of Delaware, Mar. 7, 1932; ARTHUR ROBERT BURNS, THE DECLINE OF COMPETITION: A STUDY IN THE EVOLUTION OF AMERICAN INDUSTRY 15 (1936).

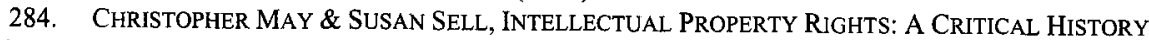
138 (2006).

285. ROBERT A. BRADY, BUSINESS AS A SYSTEM OF POWER 230-31 (1943).

286. Dan Schiller, The Legacy of Robert A. Brady: Antifascist Origins of the Political Economy of Communications, 12 J. MEDIA ECON. 89, 96-100 (1999).

287. In the patent sphere, a tying arrangement is defined as when a seller conditions the purchase of one patented product upon the purchase of staple, unpatented commodities. See DoNALD S. CHISUM, CHISUM ON PATENTS § 17.02(4) (2005). 
exclusive rights of patentees over their restraining effects on competition. ${ }^{288}$ The Supreme Court did an about-face in the landmark case Motion Picture Patents Co. v. Universal Film Manufacturing Co., where it clearly signaled that the use of the patent monopoly might be limited. ${ }^{289}$ The Court invalidated patent licensing restrictions set by movie exhibitors, which required that their patented motion picture projection equipment be resold at a set price, and that these projectors only be used with the licensor's patented film. ${ }^{290}$ The Supreme Court fully embraced the approach begun in Motion Pictures with three decisions in the early 1930s. ${ }^{291}$

Motion Pictures stated it was not the creation of pools per se, but the very use of the patent itself, that violated equitable conceptions of competition. It marked the first case where the Supreme Court recognized an affirmative defense of patent misuse. But not until Morton Salt Co. v. G.S. Suppiger in 1942 did the Supreme Court clearly outline the defense of patent misuse when the patentee sought to expand the scope of patent rights beyond what was contained within the patent grant. ${ }^{292}$ The illegal activities which were recognized as constituting patent misuse include tying, price-fixing arrangements, and patentee's post-sales restrictions on patented goods. ${ }^{293}$ Misuse was ultimately codified in $\S 251$ (d) of the 1952 Patent Act. ${ }^{294}$

Beyond patent pooling and patent misuse, there was still the suspicion that the patent grant itself was granted too readily. The idea that corporate laboratories had supplanted the lone inventor suggested to courts that ordinary improvements could now be made without granting additional patent protection. Indeed, there was increasing pressure to raise the bar for standards of patentability. ${ }^{295}$ In 1943, in thirty-four cases before the United States Circuit Courts of Appeals, courts found the relevant patent claims to be invalid for lack of invention or prior anticipation. The same year, only three patent claims were sustained and found to be

288. Heaton-Peninsular Button-Fastener Co. v. Eureka Specialty Co. (the Button-Fastener Case), 77 F. 288 (6th Cir. 1896) (finding it legal to condition the sale of patented button-fastening machines upon the purchase of unpatented fasteners); Henry v. A.B. Dick Co., 19224 U.S. 1 (1912) (affirming doctrine of the Button-Fastener case by upholding right of patentee to condition sale of patented mimeograph machine upon purchase of unpatented paper and ink). The closely divided court in $A . B$. Dick was a harbinger of the Supreme Court's decision not long afterwards to invalidate tying arrangements as anticompetitive. In addition, the Supreme Court's about-face was attributable to Section 3 of the Clayton Act, ch. $723, \S 3,38$ Stat. 730,731 (1914) (current version available at 15 U.S.C. $\S 14$ (2000)), which made exclusive relationships unlawful when their effect might be to "substantially lessen competition." Victor H. Kramer, The Supreme Court and Tying Arrangements: Antitrust as History, 69 MINN. L. REV. 1013 (1985).

289. 243 U.S. 502 (1917).

290. Id.; Susan Sell, Intellectual Property at a Crossroads: The Use of the Past in Intellectual Property Jurisprudence: Intellectual Property and Public Policy in Historical Perspective: Contestation and Settlement, 38 LOY. L.A. L. REV. 267, 306 (2004). See also Heyer v. Duplicator Mfg. Co., 263 U.S. 100 (1923).

291. Carbice Corp. of America v. American Patent Dev. Corp., 283 U.S. 27 (1931); Leitch Mfg. Co. v. Barber Co., 302 U.S. 458 (1938); Ethyl Gasoline Corp. v. United States, 309 U.S. 436 (1940).

292. 314 U.S. 488 (1942).

293. DONALD S. CHISUM, PRINCIPLES OF PATENT LAW 1084-85 (3d ed. 2004).

294. 35 U.S.C. $\$ 251$ (d) (2000).

295. HAMILTON, supra note 266 , at 156 (standards for patent novelty should be elevated, and there is little likelihood that the threshold for patents will be raised too high). 
infringed. $^{296}$ Between 1916 and 1935, the United States Supreme Court decided against patent holders in over $75 \%$ of cases.

Indeed, courts remained overwhelmingly unfriendly to patent holders even after the New Deal had passed its high water mark for reform. From 1941-1950, the United States Courts of Appeals found 129 patents valid and 399 patents invalid. ${ }^{297}$

This overturning of Patent Office decisions is especially remarkable in light of the usual deference granted administrative agency and the presumption of patent validity which is stated within the Patent Act itself. ${ }^{298}$ During the New Deal era, the Supreme Court found non-invention in a string of cases. ${ }^{299}$ In Electric Cable Joint Co. v. Brooklyn Edison Co., for example, a patent for an improved electric cable was invalidated as a mere combination of elements which was obvious to a person skilled in the prior art. ${ }^{300}$ Less than a decade later, the bar for inventiveness was again raised. In the 1941 case of Cuno Corp. v. Automatic Devices Corp., Justice William O. Douglas demanded a showing of a "flash of creative genius." 301 In Great A\& P Tea Co. v. Supermarket Equip. Corp., the Court introduced the synergy test-the "concert of known elements must contribute something; only when the whole in some way exceeds the sum of its parts is the accumulation of old devices patentable."302 Justice Robert H. Jackson remarked in a 1949 dissent that "the only patent that is valid is one which this Court has not been able to get its hands on."303

Patent was seen as a quintessentially monopolistic doctrine. It was a barrier to economic recovery. Patent holders might take advantage of the attempt to spur the mass production of consumer goods to extend their monopoly. Justice Jackson wrote, for example, that there was a risk in the demand for new appliances that "the

296. Sergei S. Zlinkoff, Monopoly Versus Competition: Significant Trends in Patent, Anti-Trust, Trade-Mark, and Unfair Competition Suits, 53 YALE L.J. 514, 520-21 (1943-44); see also GUSTAV Drews, THE PATENT Right IN THE National ECONOMY OF THE UNITED States 4-5 (1952).

297. Lawrence Baum, The Federal Courts and Patent Validity: An Analysis of the Record, $56 \mathrm{~J}$. PAT. OFF. SOC'Y 758, 760 (1974).

298. 35 U.S.C. $\S 282$ (1970) ("A patent shall be presumed valid . . . The burden of establishing invalidity of a patent or any claim thereof shall rest on the party asserting such invalidity"); Baum, supra note 297 , at 763 .

299. See, e.g., Honolulu Oil Corp. v. Halliburton, 306 U.S. 550 (1939); Textile Mech. Works v. Louis Hirsch Textile Mach., Inc., 302 U.S. 490 (1938); Altoona Publix Theatres, Inc. v. Am. Triergan Corp., 294 U.S. 477 (1935); Elec. Cable Joint Co. v. Brooklyn Edison Co., 292 U.S. 69 (1934).

300. 292 U.S. 69, 79 (1934). See also Alan P. Klein, A Funny Thing Happened to the NonObvious Matter Condition on Its Way to the Federal Circuit, 6 U. BALT. INTELL. Prop. L.J. 19, 23 (1997) (showing the Federal Circuit's retreat from the New Deal higher standard of inventiveness for patents); Rochelle Cooper Dreyfuss, The Federal Circuit: A Case Study in Specialized Courts, 64 N.Y.U. L. REV, 1, 7 (1989) (describing difficulty of pursuing enforcement of patent rights in the Second Circuit and, to a lesser extent, in the Seventh Circuit prior to the creation of the Federal Circuit).

301. Cuno Engineering Corp. v. Automatic Devices Corp., 314 U.S. 84 (1941). According to the Federal Circuit, , the non-obviousness standards articulated in the Patent Act, requiring ordinary skill in the art at the time of invention, overrules the flash of genius standard of Cuno. Ryko Manuf. v. Nu-Star, Inc., 950 F.2d 714, 718 (Fed. Cir. 1991).

302. Great A\&P Tea Co. v. Supermarket Equip. Corp., 340 U.S. 147, 152 (1950). Indeed, the bar to patents became so high that Congress enacted $\S 103$, the non-obviousness standard in the 1952 Patent Act. See 35 U.S.C. $\$ 103(2000)$.

303. Jungerson v. Ostby \& Barton Co., 335 U.S. 560, 572 (1949) (Jackson, J., dissenting). 
heavy hand of tribute be laid on each slight technological advance in an art."304 The creation of the exclusive privileges of patent law "creates a class of speculative schemers who make it their business to watch the advancing wave of improvement, and gather its foam in the form of patented monopolies, which enable them to lay a heavy tax upon the industry of the country, without contributing anything to the real advancement of the arts. ${ }^{" 305}$

\section{B. The Limits of NeW Deal Reform}

Patents were seen as beneficial to manufacturers, not inventors. Indeed, in the midst of an economic depression, there was some concern with the fact that patents might be used to foster technological innovation which could displace workers. Quite remarkably, a bill was proposed in 1937, which stated that "no patent was to be issued under the Patent Laws ... for the invention or discovery of any laborsaving machine or device or improvement thereof." 306 But the most notable recurrent theme was the displacement of individual inventors by emerging industrial research and development. Much as copyright was based on the idea of authorship, patent rights rested upon a cultural discourse celebrating courageous, hard-working lone inventors, professionals such as Thomas A. Edison or amateurs such as the Wright Brothers. ${ }^{307}$ Increasingly, however, critics of the patent system pointed to this mythic image as outdated. ${ }^{308}$

In an essay claiming the patent system was obsolete, Yale Law School professor Walton Hamilton stated that the pecuniary incentives of the patent system were designed specifically for lone inventors. ${ }^{309}$ According to Hamilton, a technical revolution took place in the early twentieth century making research a cooperative task under the auspice of business. ${ }^{310}$ Robert S. Lynd, then a young sociologist at Columbia University, spoke of the threat corporate control over invention in an age of science posed to "the institutions of democracy."

304. Cuno Engineering, 314 U.S. at 92.

305. Id.

306. H.R. 8508, 75th Cong. § 2 (1937); DREws, supra note 296, at 3. See also the discussion of proposals to make patents broadly available as "necessary to the national defense or required by the public health or public safety," WILLIAM R. BALLARD, THERE IS NO MYSTERY ABOUT PATENTS (1946) (seeking a middle ground between a radical overhauling of patent and claims that the patent system should remain untouched by New Deal legal reform).

307. THOMAS P. HUGHES, AMERICAN GENESIS: A CENTURY OF INVENTION AND TECHNOLOGICAL ENTHUSIASM 1870-1970 20-23 (1989).

308. Increasingly, courts rejected the notion of the mythology of the lone inventor, favoring employer's over employees as the assignees of rights in inventions. This position is clearly articulated in Peck v. Standard Parts Co., 282 F. 443, 446 (6th Cir. 1922) (hiring to invent conveys to employer entire ownership interest in invention). See also Catherine Fisk, Removing the "Fuel of Interest" from the "Fire of Genius": Law and the Employee Inventor, 1830-1930, 65 U. CHI. L. REV. 1127 (1998). This shift is notable since in the late nineteenth century patents were identified with upward mobility. B. Zorina Khan, The Democratization of InVEntion: Patents and Copyrights in American ECONOMIC DEVELOPMENT 1790-1920 219-221 (2005).

309. Walton Hamilton, Is Our Patent System Obsolete? Yes, 17 AM. Scholar 470 (1947-48).

310. Id. at 471 .

311. Robert S. Lynd, "You Can't Skin a Live Tiger ..." 18 AM. SCHOLAR 109 (1948). 
percent of patents were issued to corporations. By 1950, over three-quarters of patents were assigned to corporations. ${ }^{312}$ The shift to a majority of patents being filed by businesses took place in the 1930s. ${ }^{313}$ Many patentees sold or licensed their inventions to corporations, which would have been better able to exploit them in a market that demanded increasingly high entry costs. In a 1944 case, one Supreme Court Justice complained that patent law had lost its original purpose to create incentives for individual invention. ${ }^{314}$

Even as this shift occurred, corporations promoted the mythic image of the lone inventor. For example, in the early 1920s, Du Pont launched an advertising campaign with idealized depictions of a scientist in a laboratory apron, his muscular arm with unrolled sleeve held upwards with a test tube in hand. "This is today's Prometheus," the picture was captioned, "Bringer of comforts ..., The Chemical Engineer!" The advertisements pointedly reminded the consumer that the "debt to The Chemical Engineer is one that can never be paid." 315 But reality was very different. New scientific knowledge was created within large industrial combinations, and was seen as an instrument of capital accumulation. Drawing on the model pioneered by German chemical and pharmaceutical companies, United States firms also began to embark upon scientific teamwork (Wissenschaftliche Massenarbeit). General Electric established a research and development laboratory in 1900. Du Pont opened such a facility two years later. AT\&T's laboratory was founded in $1907 .^{316}$ These capital-intensive industrial laboratories with their sophisticated equipment, focused on the cooperative production of technical knowledge with coordination under a unitary management structure. They fostered the clear understanding that any marketable results were the property of the corporation. New corporate scientists - such as Charles Steinmetz in electricity, Reginald Fessenden and Lee de Forest in wireless communications, and Irving Langmuir in incandescent filaments-were firmly entrenched in the corporate structure. ${ }^{317}$

By 1921, nearly nine hundred industrial laboratories were operating mostly under the auspices of large corporations. ${ }^{318}$ As a result, the number of U.S. Patents granted rose considerably, reaching $1,002,478$ in 1911. Corporate research laboratories had successfully suppressed competition between individual inventors,

312. David F. Noble, America By Design: Science, Technology, and the Rise of CORPORATE CAPITALISM 87 (1977).

313. Larry Owens, Patents, the "Frontiers" of American Invention and the Monopoly Committee of 1939: Anatomy of a Discourse, 32 TECH. \& CULTURE 1076, 1080 (1991) (according to Commissioner of Patent Office, corporations represent a majority of those filing patents by 1938).

314. Goodyear Tire \& Rubber Co., Inc. v. Ray-O-Vac Co., 321 U.S. 275, 280 (1944) (Black, J., dissenting) ("It is impossible for me to believe that Congress intended to grant monopoly privileges to persons who do no more than apply knowledge which has for centuries been the universal possession of all").

315. Marchand, Creating the CorPorate Soul, supra note 22, at 194-95. The Du Pont public relations campaign was part of an investment in corporate reputation associated with trademark protection of goodwill and the emergence of mass media.

316. NOBLE, supra note 312 , at 112-14.

317. OLIVER ZUNZ, WhY THE AMERICAN CENTURY? 9-15 (1998).

318. Id. at 10. 
and shifted the competition to a race between the financial interests that organized the laboratories. ${ }^{319}$ However, as contemporary economists realized, both individual proprietary rights-through which a single holder might hold other patent holders hostage and thereby create barriers to further innovation in the industry as a whole - and large patent pools-with the threat of powerful monopolies-posed dangers of retarding technological advancement. ${ }^{320}$

Near the very beginning of the New Deal, patents came under scrutiny as anticompetitive. The Temporary National Economic Committee (TNEC), established by joint resolution of Congress in 1938 at the behest of Roosevelt, met for thirty months of hearings to investigate anti-competitive aspects of the United States economy. It issued a final report on March 31, 1941, which recommended amending patent laws in order to "prevent their use to suppress inventions and to create industrial monopolies." ${ }^{321}$ According to the TNEC report, the patent monopoly had been "used as a device to control whole industries, to suppress competition, to restrict output, to enhance prices, to suppress inventions, and to discourage inventiveness." 322 The TNEC recommended that Congress enact legislation that restricted the power to license. Holders of patent licenses would no longer be permitted to restrict a licensee's size of production, price, use, or set geographic scope. Patent owners would face possible forfeiture of their patents if they violated these limits on licensing.

The TNEC asked Congress to pass a statute which would transform patent licenses from being agreements based upon the will of the parties to those which reflected equitable considerations. It thus recommended that "Congress enact legislation which will require that any future patent is to be available for use by anyone who may desire its use and who is willing to pay a fair price for the privilege. ${ }^{323}$ Machinery, either judicial or administrative, should be set up to determine whether the royalty demanded by the patentee may fairly be said to represent reasonable compensation or is intended to set a prohibitive price for such use." 324 What the TNEC was suggesting, of course, was an open patent pool

319. Peter Drahos \& John Braithwaite, Intellectual Property, Corporate Strategy, Globalization: TRIPS in Context, 20 WIS. INT'L L.J. 451, 454-554 (2002). Susan Sell, Intellectual Property and Public Policy in Historic Perspective: Contestation and Settlement, 38 LoY. L.A. L. REV. 267, 304 (2004); Potts v. Coe, 145 F.2d 27 (D.C. Cir. 1944). See also Monsanto Chemical Co. v. Coe, 145 F.2d 18, 21 (D.C. Cir. 1944) ("industrial empires have been given power to suppress production and to organize domestic and international cartels through patents of carelessly defined scope which created a prima facie monopoly right over technical information").

320. Alfred E. Kahn, Fundamental Deficiencies of the American Patent Law, 30 AM. ECON. REV. 475 (1940).

321. STAFF OF Temporary National ECONOMIC COMM., 77TH CONG., INVESTIGATION of CONCENTRATION OF ECONOMIC POWER 18 (Comm. Print 1941) [hereafter TNEC Report]). See also generally Owens, supra note 313.

322. TNEC Report, supra note 321; STACY V. JONES, THE PATENT OFFICE 167 (1971).

323. TNEC Report, supra note 321, at 36. See also S.C. GILfILLAN, THE SocIOLOGY OF INVENTION 125-130 (1935) (recommending compulsory pooling and licensing of all patents, and taxation of underutilized patents).

324. TNEC Report, supra note 321 , at 36 . Rexford Tugwell envisioned a controlling body which would organize the economy, permit collaboration among corporations, and impose arrangements for patent-pooling to maximize efficiency. REXFORD TUGWELL, INDUSTRIAL DISCIPLINE AND THE 
scheme with significant oversight as to the fairness of pricing.

Moreover, the TNEC recommended to Congress a number of other significant changes in patent law. It recommended that all sales, license, assignments, or other dispositions of patents be evidenced by a written instrument that would be filed with the Federal Trade Commission within thirty days of execution. ${ }^{325}$ In order to prevent the use of aggressive infringement as a business tactic, the TNEC called for limiting patent infringement suits. ${ }^{326}$ It also recommended that a single Court of Patent Appeals be established. ${ }^{327}$

To bolster its contention that patent had become an instrument of corporate monopoly and was ripe for radical revision, the TNEC sponsored a monograph, Patents and Free Enterprise, written by Yale Law Professor Walton Hamilton. ${ }^{328}$ This work was rooted in the idea that "in its very nature the law of patents is public law," and constituted simply a grant of private equity within the public domain. ${ }^{329}$

The TNEC Report and mounting criticism from academics, politicians, and the pubic reached a crescendo by the mid-1930s. Congress considered various approaches. The Sirovich Bill, which was debated in 1935, would have required that patent pooling arrangements be registered with the Commissioner of Patents, who might then request FTC action if these were anti-competitive. ${ }^{330}$ Compulsory patent licensing was also debated in Congress. Throughout the first half of the twentieth century a number of patent compulsory licensing bills were introduced. ${ }^{331}$

The King Bill of 1935, for example, would have required the issuing of compulsory licenses under various conditions, including the failure to use an invention within a reasonable time (five years) of the patent registration. Moreover, the unfair competition provisions of the King Bill sought to restrain the anti-competitive effect of holding a number of important patents in a given area of invention. The bill proposed barring the holding of actually or potentially competitive patents to those already by a patentee. While supplemental or complementary patents to those held would be secured, these would require the approval of the Federal Trade Commission, which might have issued an order of

GOVERNMENTAL ARTS 213 (1931).

325. TNEC Report, supra note 321 , at 37.

326. Id.

327. Id.

328. HAMILTON, supra note 266. For a work supporting patentees' rights and directly opposed to the TNEC report, see George W. Folk, PATENTS AND IndUSTRIAL PRogress (1942). The TNEC report spawned a polemical literature. See, e.g., BALLARD, supra note 306 (suggesting un-American collectivists seek to undermine patent system's protection of legitimate property rights).

329. HAMLTON, supra note 266 , at 151.

330. H.R. 4523, 74th Cong. $\$ 6$ (1935). Committee Reports of the Section of Patent, Trade Mark and Copyright Law of the American Bar Association, 17 J. PAT. OfF. SOC'Y 645 (1935); HAWLEY, supra note 44 , at $368-70$.

331. These include the Oldfield Bills, H.R. 15,989, 63rd Cong. (1914); Paige Bill, H.R. 19,187, 63rd Cong. (1914); Stanley Bill, S. 3410, 67th Cong. (1922); King Bills, S. 203, 71 st Cong. (1929); S. 22, 72nd Cong. (1931); S. 290, 73rd Cong. (1933); and S. 383, 74th Cong. (1935). For a discussion of this legislative history, see Committee Reports of the Section of Patent, Trade Mark and Copyright Law of the American Bar Association, 17 J. PAT. OFF. SOC'Y 645 (1935). 
revocation. ${ }^{332}$ Although the King Bill did not pass, the extent of the FTC's proposed scrutiny was a worrisome signal that antitrust might be used to curb the latitude of patent holders.

The failure of Congress to act did not deter those in the Roosevelt administration who believed that patents represented a form of monopoly, and especially those in the Justice Department, where this sentiment was quite strong. On December 11, 1939, the Justice Department reported the results of a far-ranging investigation into patent practices, the first of its kind. In its report, the Department stated that patents had been used to establish price fixing schemes, divide markets so as to establish geographic exclusivity, enter into agreements in order to restrict production and use of the products, and enforce tying provisions. ${ }^{333}$ Otto Raymond Barnett, the former president of the American Patent Law Association, complained that the Justice Department, under the administration of Thurman Arnold, had decided that patent protection was "essentially monopolistic in character," and that anyone who "asserted and relied on patent protection walked with criminals." Barnett attributed to patent critics the idea that "the Sherman Act impliedly repealed the patent laws." 334

Arnold, who was appointed by President Roosevelt to head the Antitrust Division in 1938, himself laid out the scaffolding of his critique of patent law in an essay published in the Atlantic Monthly. ${ }^{335}$ Arnold painted a picture of a whole industrial economy - housing, transportation, and consumer goods - held up by shortages in its basic building blocks created by monopolistic combinations. Cartels had used the patent system, Arnold claimed, as the "principal smoke screen," under which to limit competition, and he urged-as was done with magnesium and rubber production - the "taking up of one industry at a time and breaking down, through anti-trust prosecutions, the power of the cartel groups" who limited mass production through the exercise of patent rights. ${ }^{336}$

In 1942, the Justice Department sponsored a remarkable bill to provide for the forfeiture of patent rights in the case of an owner or holder of a patent who had been found guilty for violation of any law relating to unlawful restraint of trade. The patents held by such person, who has been convicted under the Sherman Act, the Clayton Act, or other anti-monopoly statutes, would not have been enforceable by himself or his assignee. ${ }^{337}$

This bill elicited a great deal of opposition and did not pass. Nevertheless, there was a sense that the new frontier for antitrust was patent law. The very success of

332. S. 383 , 74th Cong. (1935).

333. Investigation of the Misuse of Patent Privileges (Dep't of Justice Dec. 11, 1939); Ernest S. Meyers \& Seymour D. Lewis, The Patent "Franchise" and the Antitrust Laws, 30 GEO. L.J. 260, 260 (1941-42).

334. Otto Raymond Barnett, Patent Property and the anti-Monopoly laws iii-iv (Indianapolis: Bobbs-Merrill Co. 1943).

335. Thurman Amold, The Abuse of Patents, ATLANTIC MONTHLY, July 1942, at 14.

336. Id. at 16,20. See also Mark Fenster, The Symbols of Governance: Thurman Arnold and PostRealist Legal Theory, 51 BuFF. L. REV, 1053 (2003); Douglas Ayer, In Quest of Efficiency: The Ideological Journey of Thurman Arnold in the Interwar Period, 23 STAN L. REV. 1049 (1971).

337. S.2783, 70th Cong. (1928). 
the New Deal in reawakening a dormant economy had resulted in industrial concentration which relied, in part, upon its control of intellectual property. In 1950, Justice Douglas wrote in prophetic tones that the earlier Progressive Era members of the Supreme Court, Justice Brandeis and Chief Justice Stone,

were alert to the danger that business-growing bigger and bigger each decadewould fasten its hold more tightly on the economy through the cheap spawning of patents, and would use one monopoly to beget another through the leverage of key patents. They followed in the early tradition of those who read the Constitution to mean that the public interest in patents comes first, reward to the inventor, second. ${ }^{338}$

Two important, very late changes finally allowed patentees to counter appellate courts with a tradition of hostility to patents. Ironically, the first of these-the creation of a Patent Court of Appeals-had first appeared in the radically antipatent TNEC report. However, the founding of the Federal Circuit, which was founded in 1982, proved to be a bastion for the upholding of patent rights. The second change was the revolution of antitrust law in the 1970 s, when under the influence of Ward Bowman and Robert Bork antitrust litigation focused on the effects of cartels on consumer welfare rather than upon competitors, allowing patent law the opportunity to rid itself of the bête noire of antimonopoly.

\section{CONCLUSION}

\section{A. Towards a New History of Intellectual Property}

One of the remarkable features of the debate over the extent of intellectual property rights is the missing voice of historical scholarship. Justification for extensive property rights in intangibles has been founded largely upon philosophical arguments-labor, personality, and utilitarian arguments-as if these emerge as reified categories independent of the political, economic, and cultural policy debates of the time. ${ }^{339}$ The legal history of intellectual property so far has attracted remarkably little attention as a source of normative principles for framing relevant law. ${ }^{340}$ In this Article, I have tried to return the contingent, the

338. Automatic Radio Mfg. Co., Inc. v. Hazeltine Research, Inc., 339 U.S. 827, 837 (1950) (Douglas, J., dissenting). See also Standard Oil Co. of California v. United States, 337 U.S. 293 (1949) (antitrust laws were effective against older unlawful tactics, such as price fixing in the restraint for trade, but had proved ineffective against "monopolies built in [a] gentlemanly way[].").

339. There is a rather broad literature on the justification of intellectual property rights, and frequent references to the problem within case law. See, e.g., Justin Hughes, The Philosophy of Intellectual Property, 77 GEORGETOWN L.J. 287 (1988); James Child, The Moral Foundations of Intangible Property, 73 THE MONIST 578 (1990); William Fisher, Theories of Intellectual Property, in NEW EsSAYS IN THE Legal AND POLITICAL THEORY OF PROPERTY 168 (Stephen R. Munzer ed., 2001); Wendy J. Gordon, A Property Right in Self-Expression: Equality and Individualism in the Natural Law of Intellectual Property, 102 YALE L.J. 1533 (1993); Edwin C. Hettinger, Justifying Intellectual Property, 18 PHIL. \& PUB. AFF. 31 (1989); Jeremy Waldron, From Authors to Copiers: Individual Rights and Social Values in Intellectual Property, 68 CHI.-KENT L. REV. 841 (1993); Alfred Yen, Restoring the Natural Law: Copyright as Labor and Possession, 51 OHIO ST. L.J. 517 (1990).

340. One notable, quite recent exception is Christopher Sprigman, Reform(aliz)ing Copyright, 57 
contentious, and the particular contours of the New Deal era, which remains the formative period for contemporary intellectual property law.

Even when invoked, legal historical scholarship has had little impact upon contemporary intellectual property debates. The optic for the mainstream legal history of United States intellectual property simply takes for granted that the core narrative is the response to new technologies. According to Paul Goldstein, for example, "every encounter between copyright and a new technology, from the printing press to the celestial jukebox, has presented a stark choice of lawmakers ...."341 The technological improvements in printing, player pianos, phonograph records, radio, film, television, video recorders, computer software, and Internet communications punctuate copyright's chronological narrative. ${ }^{342}$ This is also an especially attractive approach in the area of patents. ${ }^{343}$

Perhaps the best example is an admirable essay by Robert Merges describing the ways that intellectual property law encounters new technologies - fearful of its inadequacies and scrambling to meet the challenge of novel inventions. In Merges's scheme, adaptation takes place in three steps. First, there is an early period of uncertainty-"disequilibrium" in his words-when the legal rules surrounding the new technology diverge. This is followed by "an extended period of adaptation, when general doctrines developed in earlier eras are applied and modified on a case-by-case basis." Finally, these doctrinal innovations are incorporated, sifted, and codified by a broader legislative thrust towards statutory revision. ${ }^{344}$

Merges urges legislatures to provide space for common law evolution. Broad enabling amendments provide maneuvering room for courts. Detailed, technology driven, industry specific statutes, on the other hand, constrain the elaboration of rules that might slowly work out the balance between different interests. The inability to abide the uncertainty, indeed the anxieties, of the initial period of confusion in a period when intellectual property has become increasingly a matter of economic high stakes might make legislatures vulnerable to the influence of interest groups - and, ultimately, might result in an over-protectionist and rentseeking statutory framework.

There is much to commend the model of paradigm shifts in intellectual property law prompted by new technologies. Copyright, for example, has often experienced

STAN. L. REV. 485 (2004) (showing how formalities in the 1909 and earlier Copyright Acts provided an important mechanism to allow works to fall into the public domain).

341. GOLDSTEIN, supra note 120 , at 29.

342. See, e.g., EDWARD SAMUELS, THE Illustrated StORY OF COPYRight 9-124 (2000) (the first section, entitled "Copyright and Technology," traces copyright from books to the internet).

343. See, e.g., Brienna Dolmage, The Evolution of Patentable Subject Matter in the United States, 27 WhITTIER L. REV. 1023, 1044 (2006) (describing legal responses to patent subject matter requirement with new technologies). An exception to this approach, which deeply contextualizes intellectual property law within the mental landscape is Michael Birnhack, The Idea of Progress in Copyright Law, 1 BUFF. INTELL. PROP. L.J. 3 (2001) (notions of progress vary according to time and place, providing flexibility in the construction of copyright norms).

344. Robert P. Merges, One Hundred Years of Solicitude: Intellectual Property Law, 1900-2000, 88 CAL. L. REV. 2187 (2000). This hitherto has been the only major attempt to achieve a broad understanding of the trends in twentieth-century intellectual property law. 
the anxieties of innovation. The Copyright Act of 1790, which protected merely maps, charts, and books, has repeatedly expanded to a vertiginous landscape of new technologies, including photographs, moving pictures, phonograph recordings, piano rolls, and more recent technologies such as electronic databases, computer software, peer-to-peer internet music sharing, and the near perfect digital reproduction of images. ${ }^{345}$ In each of these cases, courts and legislatures have experienced uncertainty prior to accommodation. The Supreme Court found no copyright infringement in the copying by a competitor of perforated music rolls designed for player pianos, and this troubling decision helped prompt the revision of copyright law which resulted in the 1909 Copyright Act. ${ }^{346}$

However, not all changes in intellectual property law can so easily be ascribed to the emergence of new technologies. Rights of publicity, for example, might be said to reflect new media technologies which provide for the mechanical reproduction of voice or images of identity. Alternatively and perhaps more persuasively, such rights reflect a striking change of attitude transforming a right of privacy into a right to commercial exploitation, on the theory that celebrities "would feel sorely deprived" if they could not authorize the use of their image for advertisements. ${ }^{347}$ Business method patents arguably reflect a need to create additional property rights in a time when employee loyalty to corporations is more attenuated. ${ }^{348}$ Trade secret law, neatly described over the course of the nineteenth century by Catherine Fisk, requires the rise of the corporation as a persona with its own rights. ${ }^{349}$

This Article is an attempt to construct a less technology oriented narrative for intellectual property history - one deeply situated in a wide array of agendas, and historically embedded in social, political, and economic contexts. It is one where political economy informs the history of intellectual property more broadly. ${ }^{350}$ Certainly, new technologies do prompt doctrinal rethinking. But these technologies are placed within the framework of competing interests and economic ideologies, and the new technologies themselves are less important than the overarching dilemmas posed by the problem of fitting inherited legal categories to new ways of

345. Copyright Act of 1790 , ch. 15, 1 Stat. 124 (1790). On the emergence of new copyright technologies, see generally SAMUELs, supra note 342, at 9-124; GoLDSTEIN, supra note 120; Jane C. Ginsburg, Copyright and Control Over New Technologies of Dissemination, 101 COLUM. L. REV. 1613 (2001) (describing how new technologies prompt Congressional accommodation extending copyright protection to new markets).

346. White-Smith Music Publishing Co. v. Apollo Co., 209 U.S. 1 (1908).

347. Haelen Laboratories, Inc. v. Topps Chewing Gum, Inc., 202 F.2d 866, 868 (2d Cir. 1953).

348. State Street Bank and Trust Co. v. Signature Financial Group, Inc., 149 F.3d 1368 (Fed. Cir. 1998) (permitting patent of business methods when they produce a useful, concrete, and tangible result). This argument is consistent with the framework in KATHERINE V.W. STONE, FROM WIDGETS TO DIGITS: EMPLOYMENT REGULATION IN THE CHANGING WORKPLACE (2004) (describes a framework where employers no longer value long-term employee attachment).

349. Catherine Fisk, Working Knowledge: Trade Secrets, Restrictive Covenants in Employment and the Rise of Corporate Intellectual Property 1800-1900, 52 HASTINGS L.J. 441 (2001); Catherine Fisk, Removing the "Fuel of Interest" from the "Fire of Genius": Law and the Employee Inventor, 1830-1930, 65 U. CHI. L. REV. 1127 (1998).

350. On thinking about comparative political economy as an architectural framework for legal doctrine, see John C. Reitz, Political Economy as a Major Architectural Principle of Public Law, 75 TUL. L. REV. 1121, 1121-23. 
thinking about legal regulation.

\section{B. Intellectual Property and its Post-War Discontents: From POLITICAL ECONOMY TO CITIZENSHIP}

In many ways, we live in an intellectual property world shaped by the four aspects of the New Deal paradigm. As I have shown, the New Deal retreated from Progressive Era antitrust and began to construct the post-war paradigm for intellectual property law - a paradigm where intellectual property is national and international, strongly proprietary, less troubled by monopoly, and seen as a motor for the economy as a whole.

The Lanham Act established the first substantive federal law of trademark. Copyright lawyers pressed Congress to adopt the Berne Copyright Convention. Today, the United States is not just a signatory to Berne, but to Paris and Madrid protocols as well. More than ever, the New Deal paradigm ideal of intellectual property qua property has been realized. Courts are currently deferential to the idea that intellectual property is a valuable commodity. Federal trademark law has adopted a variety of property-based doctrines, including dilution, intent-to-use provisions, and incontestability. An array of compulsory licenses and the Digital Millennium Copyright Act suggest the ways that Congress has fully assumed the role of umpire in the field of copyright. Although anxieties about trademark and copyright as monopoly have been quieted, we still engage in debates over the extent of patent monopoly power. The United States has made the protection of global intellectual property assets a keystone to its economic development. This protection has been linked to various trade agreements, including GATT.

But perhaps one of the most important parts of the New Deal legacy has been more difficult to sustain. In the New Deal political economy, policy debates always intermingled issues of economics and citizenship. Based on a new reading of the social sciences, trademark law recognized the psychological value of symbols and the economic value of stimulating consumer desire. It established the legal underpinnings for the consumer republic. Copyright law in the 1930s was rocked by debates over sound recordings. These debates were intimately connected with claims about the importance of media for a democratic society. Attempts to create a new copyright law for industrial design posed fundamental questions of what constitutes fair competition. In both copyright debates, competing interest groups called upon Congress to intervene as an umpire and to construct what I have called the New Deal's policy of intellectual property industrial pluralism. Patent law discussions were about the extent of corporate power. Citizenship in the era of the pax keynesiana has meant living in a world inhabited with a dizzying array of technological tools, forms of expression, and differentiated consumer goods.

As the New Deal paradigm became the post-war paradigm, the doctrinal and policy shifts occurred which would omit the core role of debates over citizenship. Regimes like copyright and trademark increasingly became identified with property rhetoric. It became acceptable to consider intellectual property as a cornerstone of United States industrial policy with internal mechanisms for establishing the proper 
balance between public and private. ${ }^{351}$

But, of course, every paradigm will eventually give rise to a post-paradigm. A post-post war paradigm may now be emerging. As intellectual property rights increase, along with the attempts to utilize them to achieve leverage in starkly competitive markets, the Justice Department seems to be more willing to initiate antitrust suits, and the courts may be more willing to entertain them. It behooves us to recall the raucous legal debates of the New Deal. The uneasy, often troubled cohabitation of citizenship and economics may be returning again.

351. See, e.g., Broadcast Music, Inc. v. Columbia Broadcasting System, Inc., 441 U.S. 1 (1979) (holding that block licensing schemes utilized by ASCAP and BMI were not a violation of antitrust laws, despite providing these organizations with the opportunity to engage in price-fixing, since they constituted the sole reasonable means for protecting the property interests of copyright holders). 
